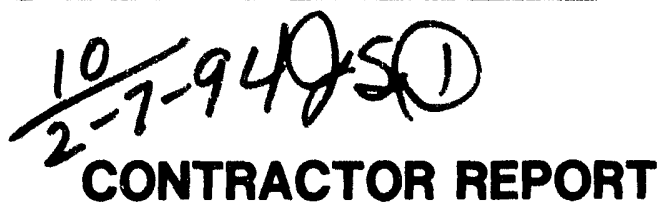

SAND93-7100 $\cdot$ UC -721

Unlimited Release

\title{
Preliminary Identification of Potentially Disruptive Scenarios at the Greater Confinement Disposal Facility, Area 5 of the Nevada Test Site
}

Robert V. Guzowski

Science Applications International Corporation

2109 Air Park Road SE

Albuquerque, NM 87106

Gretchen Newman

GRAM, Inc.

8500 Menaul Blvd., NE, Suite 321

Albuquerque, NM 87112

Prepared by Sandia National Laboratories Albuquerque, New Mexico 87185

and Livermore, California 94550 for the United States Department of Energy

under Contract DE-AC04-94AL85000

Printed December 1993 
Issued by Sandia National Laboratories, operated for the United States Department of Energy by Sandia Corporation.

NOTICE: This report was prepared as an account of work sponsored by an agency of the United States Government. Neither the United States Government nor any agency thereof, nor any of their employees, nor any of their contractors, subcontractors, or their employees, makes any warranty, express or implied, or assumes any legal liability or responsibility for the accuracy, completeness, or usefulness of any information, apparatus, product, or process disclosed, or represents that its use would not infringe privately owned rights. Reference herein to any specific commercial product, process, or service by trade name, trademark, manufacturer, or otherwise, does not necessarily constitute or imply its endorsement, recommendation, or favoring by the United States Government, any agency thereof or any of their contractors or subcontractors. The views and opinions expressed herein do not necessarily state or reflect those of the United States Government, any agency thereof or any of their contractors.

Printed in the United States of America. This report has been reproduced directly from the best available copy.

Available to DOE and DOE contractors from

Office of Scientific and Technical Information

PO Box 62

Oak Ridge, TN 37831

Prices available from (615) 576-8401, FTS 626-8401

Available to the public from

National Technical Information Service

US Department of Commerce

5285 Port Royal Rd

Springfield, VA 22161

NTIS price codes

Printed copy: A10

Microfiche copy: A01 
$\mathrm{UC}-721$

\author{
SAND93-7100 \\ Unlimited Release \\ Printed December 1993
}

\title{
PRELIMINARY IDENTIFICATION OF POTENTIALLY DISRUPTIVE SCENARIOS AT THE GREATER CONFINEMENT DISPOSAL FACILITY, AREA 5 OF THE NEVADA TEST SITE*
}

\author{
Robert V. Guzowski \\ Science Applications International Corporation \\ 2109 Air Park Road SE \\ Albuquerque, NM 87106 \\ Gretchen Newman \\ GRAM, Inc. \\ 8500 Menaul Blvd., NE, Suite 321 \\ Albuquerque, NM 87112
}

\begin{abstract}
The Greater Confinement Disposal location is being evaluated to determine whether defense-generated transuranic waste buried at this location complies with the Containment Requirements established by the U.S. Environmental Protection Agency. One step in determining compliance is to identify those combinations of events and processes (scenarios) that define possible future states of the disposal system for which performance assessments must be performed.

An established scenario-development procedure was used to identify a comprehensive set of mutually exclusive scenarios. To assure completeness, 761 features, events, processes, and other listings (FEPs) were compiled from 11 references. This number was reduced to 205 primarily through the elimination of duplications. The 205 FEPs were screened based on site-specific, goal-specific, and regulatory criteria. Four events survived screening and were used in preliminary scenario development: (1) exploratory drilling penetrates a GCD borehole, (2) drilling of a withdrawal/injection well penetrates a GCD borehole, (3) subsidence occurs at the RWMS, and (4) irrigation occurs at the RWMS. A logic diagram was used to develop 16 scenarios from the four events. No screening of these scenarios was attempted at this time.

Additional screening of the currently retained events and processes will be based on additional data and information from site-characterization activities. When screening of the events and processes is completed, a final set of scenarios will be developed and screened based on consequence and probability of occurrence.
\end{abstract}

* Work performed under contract Nos. 18-8906 and AB-5977 for Safety and Risk Assessment Department, Sandia National Laboratories, Albuquerque, NM.

\section{Mith}




\section{Acknowledgments}

Implementation of the scenario-development procedure used in this report requires coverage of a broad spectrum of technical areas. The authors would like to thank Dennis Gustafson of Raytheon Services Nevada (RSN) for providing site-specific information important in making certain screening decisions, and Duane Gibson of Department 6116 at Sandia National Laboratories (SNL) for supplying certain background information used in the site-description chapter.

Technical reviews are crucial to the successful implementation of the scenariodevelopment procedure. The authors would like to thank the following individuals for their review comments: Laura Price (Science Applications International Corporation), Paul Davis and Steven Conrad (SNL, Dept. 6331), Harlan Stockman (SNL, Dept. 6118), Duane Gibson (SNL, Dept. 6116), Joseph Ginanni (U.S. Department of EnergyNevada Operations), Lawrence Barker and Thomas Lindstrom (Reynolds Electrical \& Engineering Co., Inc.), and Dennis Gustafson and Julie Miller (RSN).

The authors would also like to thank the following Tech Reps, Inc. (TRI) employees for providing publications support: Sally Laundre-Woerner (illustrations), Julie Coffey (editing), Pat Shupe and Theresa Allen (word processing), and Carol Crawford (reference list verification). 


\section{Unit Conversions}

The trend is for scientific reports to use metric units, often followed by the English-unit equivalent. When the original units are metric, this format does not present a problem. When the original units are English, stating the metric unit first can result in misrepresentations of the degree of accuracy of the values being reported. Conversion of units from one system to another commonly results in the creation of additional significant figures through carelessness and attempts to do something with remainders. The added significant figures can produce the illusion of a level of precision that cannot be supported by the precision of the original values.

In an attempt to avoid misrepresenting the precision of the various data included in this report, the units used in the original reference are reported first. Conversion to the alternate system of units generally follows the original units. 


\section{Contents}

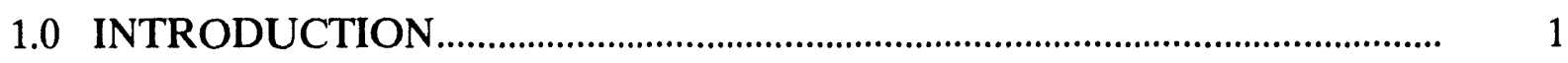

2.0 SITE DESCRIPTION ...............................................................................

2.1 Geographic Location.................................................................................

2.2 The GCD Facility ....................................................................................

2.3 Regional Geologic and Tectonic Setting ......................................................

2.4 Local Setting ..................................................................................................... 7

2.5 Stratigraphy...........................................................................................

$2.6 \quad$ Structural Setting ..................................................................................... $\quad 10$

2.7 Geomorphology................................................................................

2.8 Climate ...............................................................................................

2.9 Surface Hydrology .........................................................................................

2.10 Subsurface Hydrology ...............................................................................

3.0 REGULATORY BASIS FOR SCENARIOS …………....................................... 19

4.0 DESCRIPTION OF SCENARIO-DEVELOPMENT PROCEDURE USED FOR THE GREATER CONFINEMENT DISPOSAL SYSTEM ................. 21

4.1 Previous Approaches to Scenario Development for GCD Location ...... 21

4.1.1 Original Scenario-Development Effort for GCD Location............ 21

4.1.2 Scenario Selection for a Preliminary Performance Assessment.... 22

4.2 Revised Scenario Development for the GCD Location............................. 22

4.2.1 Step 1: Identifying Events and Processes......................................... 23

4.2.1.1 Initial List of Events and Processes ..................................... 24

4.2.1.2 Modified Initial List of Features, Events, and Processes ........................................................................ 24

4.2.2 Step 2: Classifying Events and Processes........................................ 27

4.2.3 Step 3: Screening Events and Processes .......................................... 27

4.2.3.1 Screening Criteria of the Basic Procedure........................... 27

4.2.3.2 Modifications to the Basic Screening Criteria ..................... 28

4.2.3.3 Results of Screening for GCD Location .............................. 29

4.2.4 Step 4: Constructing Scenarios.......................................................... 31

4.2.4.1 Method of Scenario Construction in Basic Procedure....... 31

4.2.4.2 Base-Case Scenario ............................................................. 36

4.2.4.3 Results of Scenario Construction for GCD Location ........ 37

4.2.5 Step 5: Screening of Scenarios ......................................................... 37

4.2.5.1 Screening Criteria of the Basic Procedure........................... 37

4.2.5.2 Screening of GCD Scenarios.................................................. 40

4.2.5.3 Plans for Completion of Scenario Identification ................ $\quad 40$ 


\section{Contents (Continued)}

5.0 SUMMARY AND CONCLUSIONS

6.0 REFERENCES

APPENDIX A: GEOLOGIC TIME SCALE

A-1

APPENDIX B: REFERENCES USED FOR GCD SCENARIO SELECTION

OF FEATURES, EVENTS, AND PROCESSES

B-1

APPENDIX C: FEATURES, EVENTS, AND PROCESSES CONSIDERED FOR THE GCD LOCATION

C-1

APPENDIX D: DISPOSITION OF FEATURES, EVENTS, AND

PROCESSES AS A. RESULT OF SCREENING

D-1

APPENDIX E: SEISMICITY IN THE NTS REGION

E-1

APPENDIX F: PLUTONIC AND VOLCANIC ACTIVITY IN THE

NTS REGION

D-1 


\section{Figures}

Figure 2-1 Location of Radioactive Waste Management Site (RWMS) at Area 5 of Nevada Test Site, Nevada............................................. 4

Figure 2-2 Schematic Representation of RWMS ............................................. 5

Figure 2-3 Schematic Diagram of a Typical GCD Borehole .............................. 6

Figure 2-4 Physiographic Provinces in Southwestern U.S....................................

Figure 2-5 Physiographic Features in Vicinity of Frenchman Flat...................

Figure 2-6 General Relationship of Hydrogeologic and

Geogeologic Units in the Southern Great Basin.............................. 11

Figure 2-7 Map Showing the General Geology and Major Structural

Features in Frenchman Flat and Vicinity.......................................... 12

Figure 4-1 Demonstration Logic Diagram for the Construction of

Scenarios for Hypothetical Events and Processes............................ 33

Figure 4-2 Complete Notation for Scenarios in Logic Diagram for

Hypothetical Events and Processes ................................................... 34

Figure 4-3 Example of the Calculation of the Probability of

Occurrence of a Scenario Developed in a Logic Diagram ............. $\quad 35$

Figure 4-4 Preliminary Scenarios Developed with a Logic Diagram

for GCD Location ........................................................................ 38 


\section{Tables}

Table 2-1

Table 4-1

Table 4-2

Table 4-3

Table 4-4

Table 4-5
Simplified Stratigraphic Column at the GCD Site.

17

Potentially Disruptive Events and Processes

25

Sources of Lists of Events and Processes Used to

Develop the GCD Master List

26

Criteria for Screening Events and Processes .

30

Events Remaining After Screening.

30

Events Used for Scenario Development. 


\subsection{INTRODUCTION}

The Nuclear Waste Policy Act (NWPA, 1982) and the Nuclear Waste Policy Amendments Act (NWPAA, 1987) specify that high-level radioactive waste (HLW), spent nuclear fuel generated by commercial reactors, and defense-generated transuranic waste (TRU) will be disposed of in proposed facilities in deep-geologic media. After demonstration of compliance with the appropriate federal regulations, HLW and SF are destined for disposal at Yucca Mountain in Nevada, and the defense TRU waste is destined for the Waste Isolation Pilot Plant in southeastern New Mexico. The disposition of high-level, defense-generated waste has not been decided at this time. Up to 10,000 metric tons of defense HLW can be disposed of at Yucca Mountain under current regulations. No plans currently exist for the disposal of amounts greater than 10,000 metric tons. Low-level radioactive waste (LLW) generally can be disposed of in near-surface facilities. Some radioactive waste does not meet the acceptance criteria of the WIPP facility. This waste is termed orphan waste.

The Greater Confinement Disposal (GCD) facility is located within the Radioactive Waste Management Site, which is in the northeastern portion of Area 5 of the Nevada Test Site. This facility was originally designed by the Nevada Operations Office of the U.S. Department of Energy (U.S. DOE/NV) to demonstrate the safe disposal of orphan waste, such as greater-than-class-C LLW, and certain other radioactive wastes, in arid environments for DOE's Defense Low-Level Waste Management Program. To demonstrate the GCD concept, a GCD Test (GCDT) borehole was augered, waste was emplaced, and the hole was backfilled in 1981. This demonstration included a monitoring system to determine the effects of the waste on the area surrounding the borehole. Starting in 1984, U.S. DOE/NV used other boreholes within the RWMS to dispose of small quantities of orphan waste. Burial of TRU waste ceased in 1987 and all other orphan waste in 1989 (Chu and Bernard, 1991). The current GCD disposal facility consists of 13 boreholes within unsaturated alluvial-fan deposits. Each borehole is approximately 10 feet ( 3 meters) in diameter and approximately 120 feet (37 meters) deep. Of the 13 boreholes, three contain nuclear-weapon accident residue (which contains TRU nuclides), one contains TRU-contaminated waste from other sources, five contain non-TRU radioactive waste, and four boreholes currently are empty (Chu and Bernard, 1991). Boreholes are filled with waste to within approximately 70 feet $(21$ meters) of the surface with the remainder of the boreholes filled with native material that had been removed during drilling (RSN, 1991).

Because some of the GCD boreholes contain TRU waste, the site will have to comply with Subpart B of the U.S. Environmental Protection Agency's (U.S. EPA) Environmental Radiation Protection Standards for Management and Disposal of Spent Nuclear Fuel, High-Level and Transuranic Radioactive Wastes-Final Rule 40) CFR Part 191 (U.S. EPA, 1985). Subpart B of the Standard contains Containment Requirements (40 CFR 191.13) that state the performance criteria for candidate disposal systems for 10,000 years after 
closure of the facilities. Compliance with these performance criteria are to be determined through the use of performance assessments. The U.S. DOE/NV placed a contract with the Safety and Risk Assessment (SRA) Department at Sandia National Laboratories (SNL) to conduct performance assessments for the GCD disposal system to determine compliance with these criteria.

A performance-assessment methodology (Campbell et al., 1978; Cranwell et al., 1987; Davis et al., 1990) previously developed at SNL to determine the compliance of HLW disposal systems with performance criteria established by the U.S. EPA and the U.S. Nuclear Regulatory Commission was adopted by the SRA Department for the GCD performance assessments. A slightly modified version of this methodology was implemented by the SRA Department to do a preliminary performance assessment of the GCD disposal system (Price et al., 1993a,b,c) One component of the methodology that was not included in this preliminary performance assessment was the use of the scenariodevelopment procedure (Cranwell et al., 1990) to identify possible future states of the disposal system.

This report documents the implementation of the scenario-development procedure (Cranwell et al., 1990) for the GCD location. The results of this report will be used in part as guidance in site characterization of the disposal system and as a source for the preliminary identification of possible future states of the disposal system for analysis by performance assessments to determine compliance with the Containment Requirements. 


\subsection{SITE DESCRIPTION}

\subsection{Geographic Location}

The Greater Confinement Disposal (GCD) facility lies within the northeastern part of Area 5 of the Nevada Test Site (NTS), which is approximately $110 \mathrm{~km}$ (68 miles) northwest of Las Vegas, Nevada (Figure 2-1). Few communities are located in the vicinity of the NTS. Within the boundaries of the NTS, the town of Mercury, which provides housing and support facilities to test-site personnel, is located approximately 20 kilometers (12.4 miles) south of the GCD location. Lathrop Wells, 50 kilometers (31 miles) southwest of the GCD, and Indian Springs, 40 kilometers (25 miles) southeast of the GCD, are the closest residential communities outside the NTS boundaries.

\subsection{The GCD Facility}

The GCD facility consists of 13 boreholes confined within the boundary of the Radioactive Waste Management Site (RWMS), where low-level waste (LLW) is buried in trenches (Figure 2-2). Based on information compiled by Chu and Bernard (1991), four boreholes contain transuranic (TRU) waste (Nos. 1, 2, 3, and 4), four boreholes contain LLW (Nos. 5, 6, 7, and 10), and four boreholes are currently empty (Nos. 8, 9, 11, and 12). All of the TRU boreholes are closed and backfilled. Two of the LLW boreholes are closed and backfilled (Nos. 5 and 10), while the other two LLW boreholes (Nos. 6 and 7) remain open. The thirteenth borehole (GCDT) contains LLW and serves as an experiment to test the feasibility of radioactive-waste disposal within boreholes drilled into the unsaturated zone at a location experiencing arid climatic conditions. GCDT is closed and backfilled.

Two of the boreholes (Nos. 1 and 2) are approximately 12 feet (3.7 meters) in diameter, and the other 11 boreholes are approximately 10 feet ( 3 meters) in diameter. Each of the boreholes is approximately 120 feet (36.6 meters) deep, and those boreholes that contain waste have the waste limited to approximately the bottom 50 feet (15.2 meters) of the borehole (Figure 2-3). Probertite, which is a boron-rich mineral, was used as backfill material around the waste packages in Boreholes 1,2, and 3. The boron in the probertite is a neutron absorber, thereby reducing the flux of neutrons within the waste and preventing the flux from reaching the levels necessary to initiate criticality. Disturbed host material produced by the drilling of the boreholes was sifted to remove larger particles and used to surround the waste in the other waste-containing boreholes without the probertite backfill and to fill in the interval from the top of the waste to the surface in all of the closed boreholes. 


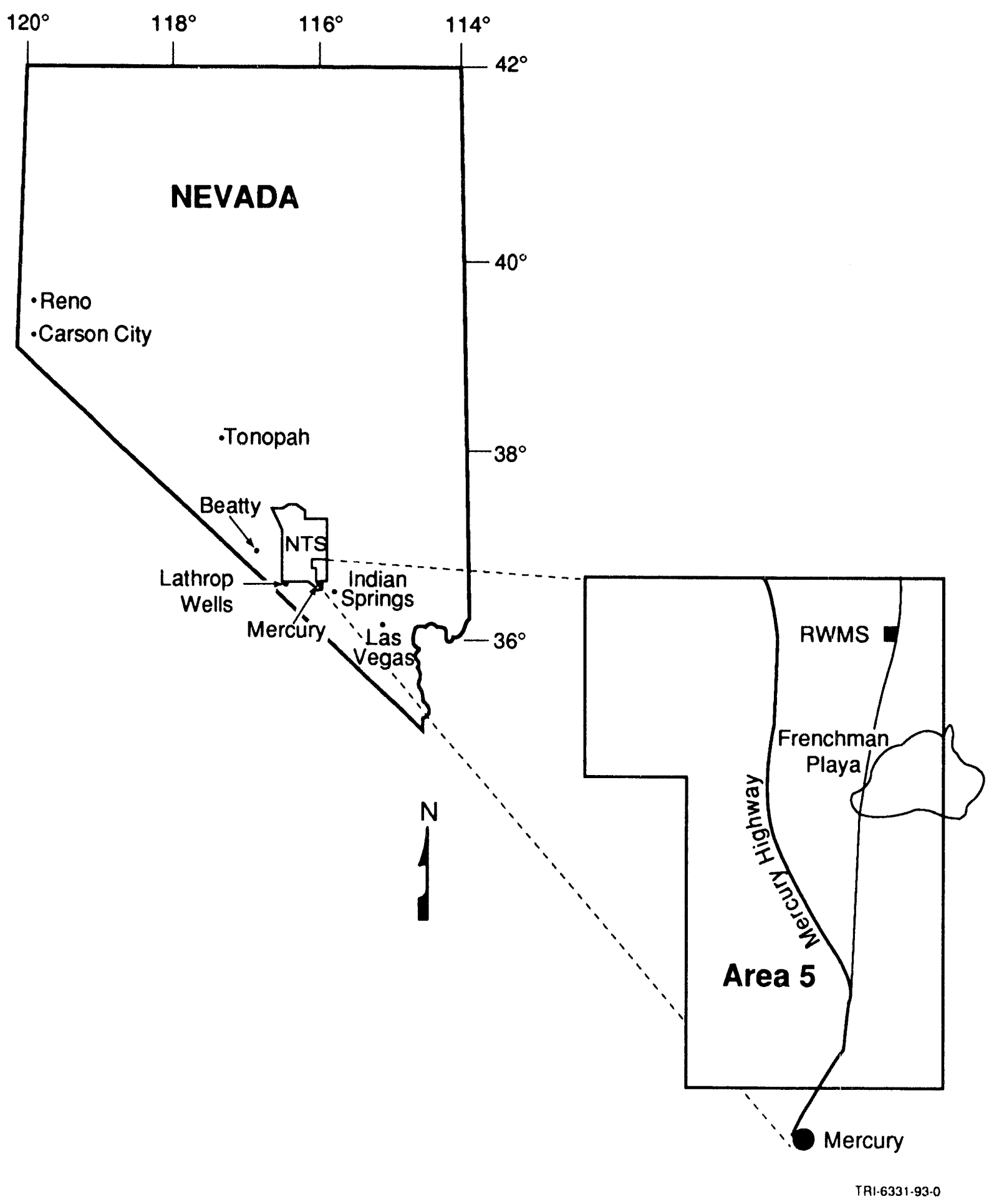

Figure 2-1. Location of Radioactive Waste Management Site (RWMS) at Area 5 of Nevada Test Site, Nevada 


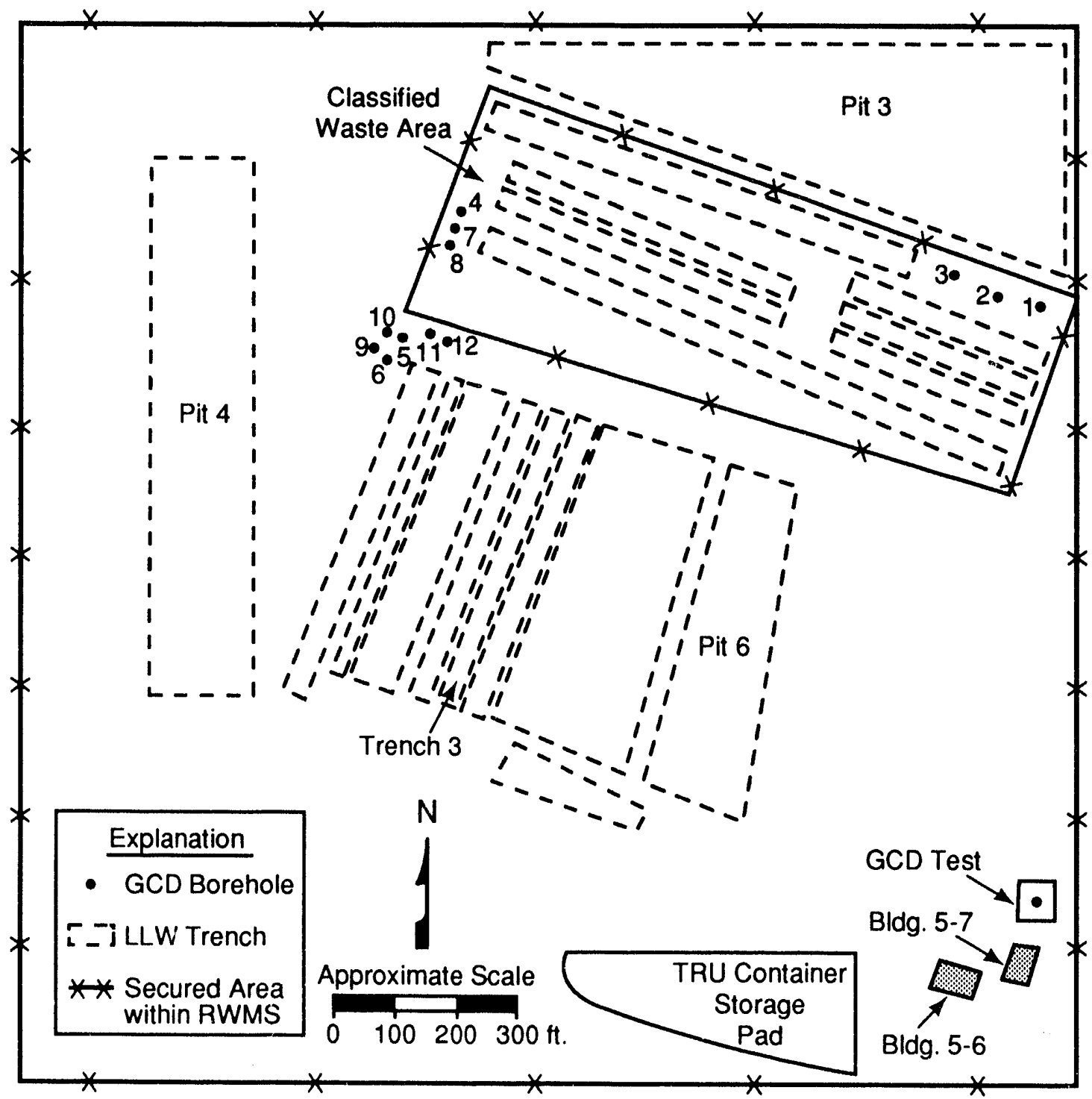

TRI-6331-97-0

Figure 2-2. Schematic Representation of RWMS (after Chu and Bernard, 1991) 


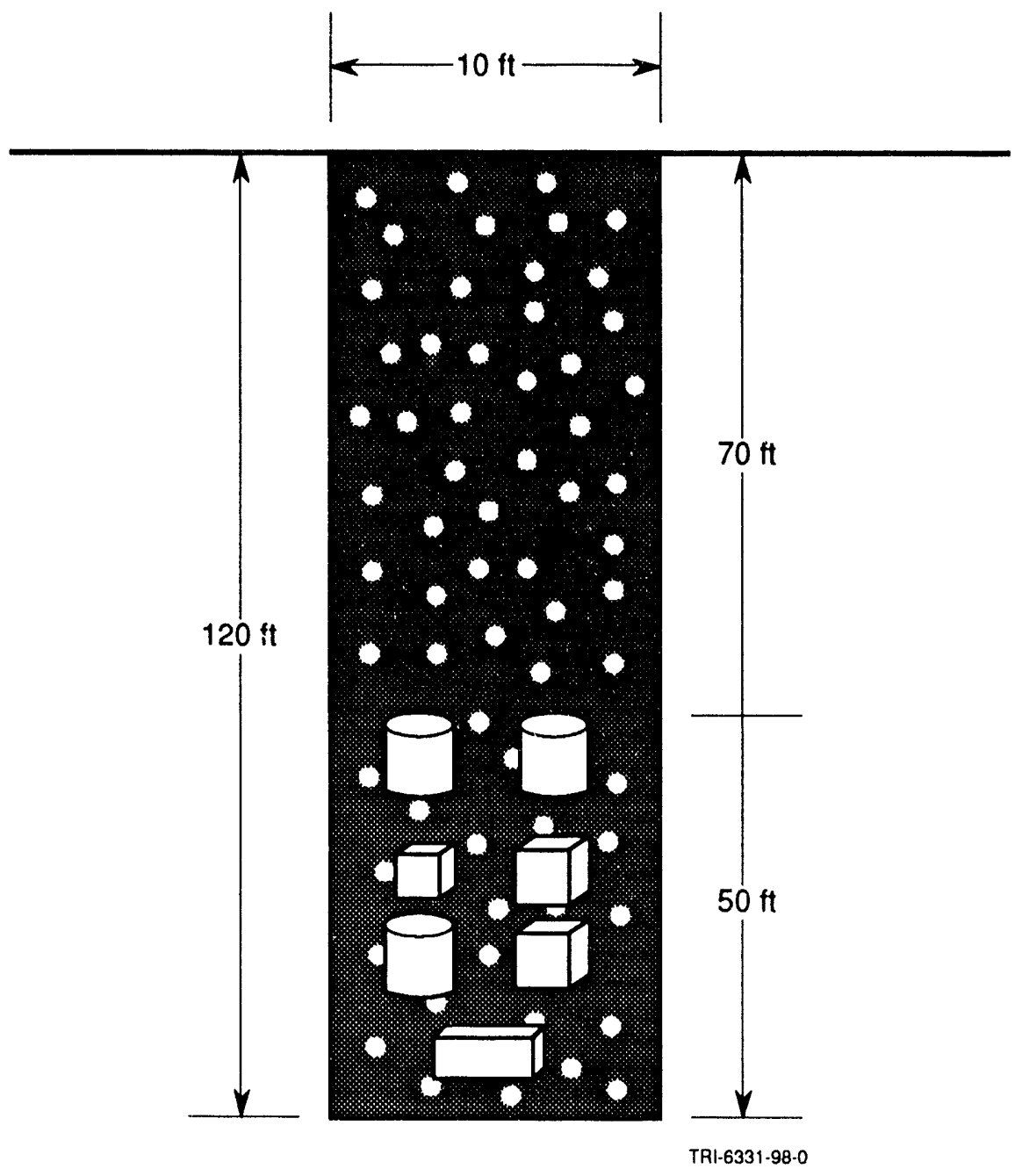

Figure 2-3. Schematic Diagram of a Typical GCD Borehole (Price et al., 1993a, after Chu and Bernard, 1991) 


\subsection{Regional Geologic and Tectonic Setting}

Most of Nevada lies within the Great Basin section of the Basin and Range physiographic province. The Great Basin consists of dominantly north-south trending, block-faulted mountain ranges that are separated by broad alluvium-filled basins. The NTS is located on the boundary between the Southeast Great Basin and the Walker Lane Belt (Carr, 1984) (Figure 2-4).

The boundaries of the Walker Lane Belt, Southeast Great Basin, and Southwest Great Basin are not well defined. The Walker Lane Belt occurs as an elongated area oriented in a northwest-southeast direction between the Southeast Great Basin and the Southwest Great Basin. The Walker Lane Belt is characterized by a broad zone of diverse topography, consisting primarily of low-relief mountain ranges separated by northwestsoutheast trending, right-lateral strike-slip faults.

\subsection{Local Setting}

The RWMS is located within the north-central part of Frenchman Flat at a surface elevation of approximately 3,200 feet (976 meters). Frenchman Flat is a topographically closed basin (Figure 2-5). The highest point in the mountains that surround the basin is at French Peak at an elevation of 5,277 feet (1,609 meters), which is located within the Massachusetts Mountains approximately 4 miles (6.4 kilometers) north of the GCD location. Frenchman Playa at an elevation of 3,081 feet (939 meters) is the lowest area within the basin.

\subsection{Stratigraphy}

Figure 2-6 provides a generalized stratigraphic section for the geologic units in the Southern Great Basin, which on a large scale includes the Southeast and Southwest Great Basins and part of the Walker Lane Belt in Figure 2-4, along with their corresponding hydrogeologic units. Not all of the geologic units in this section are present at Frenchman Flat. The geologic units at the Frenchman Flat location can be characterized by three main stratigraphic sequences. These sequences are, from oldest to youngest, (1) Precambrian through Devonian marine sedimentary rocks, (2) Tertiary volcanic rocks, and (3) Tertiary through Holocene unconsolidated basin-fill sediments locally interlayered with basaltic lava flows. The geologic equivalents of the Upper Clastic Aquitard and the Upper Carbonate Aquifer have not been identified at Frenchman Flat. A geologic time scale is included as Appendix A to provide time equivalents to the geologic-time terms used above.

The lower clastic aquitard is characterized by beds of quartzites with siltstone, shale, and minor carbonate interbeds of marine origin. This unit has an estimated thickness of 10,000 feet $(3,000$ meters $)$. Overlying the clastic aquitard is the lower carbonate aquifer, 


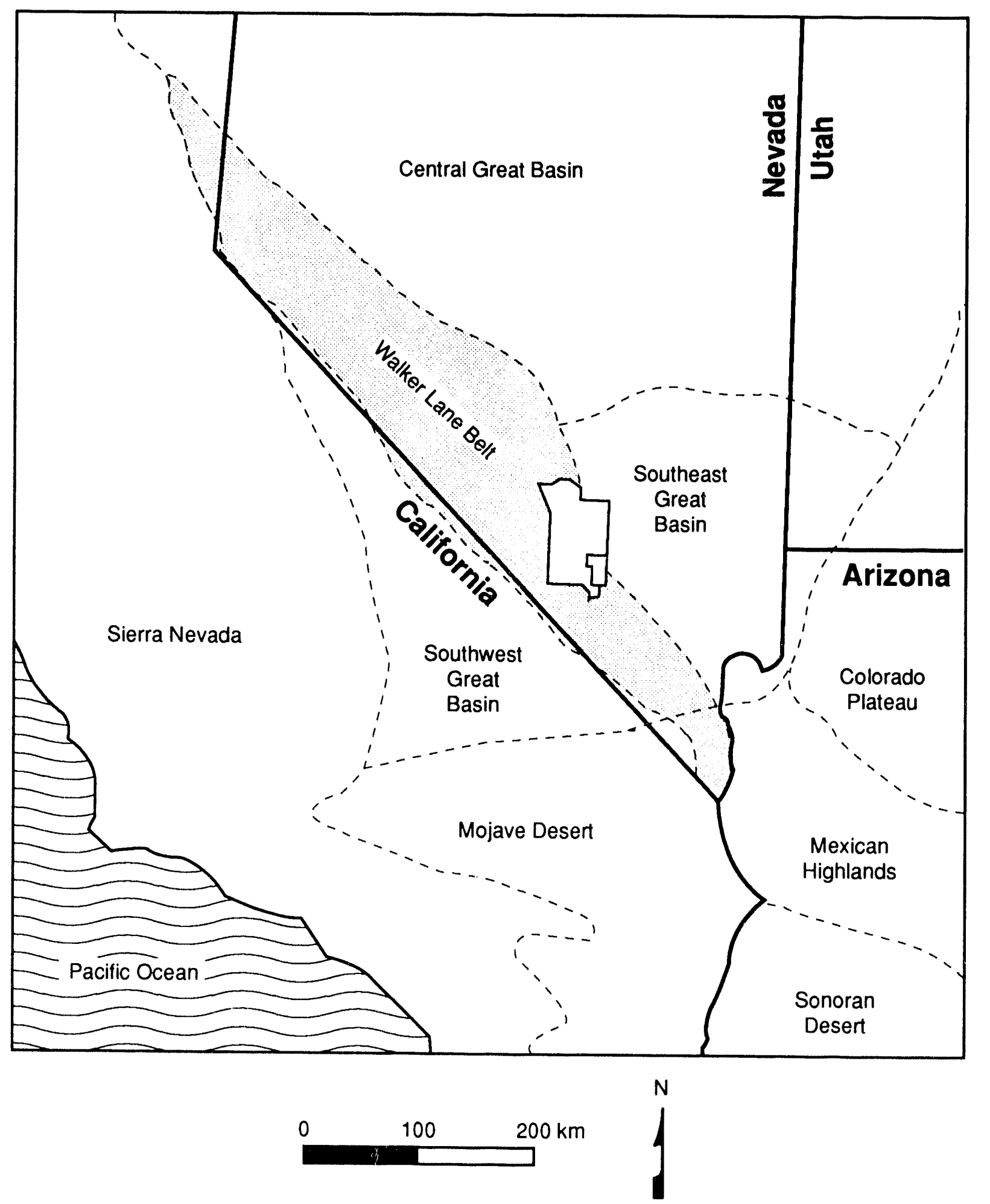

TRI-6331.92.0

Figure 2-4. Physiographic Provinces in Southwestern U.S. (after U.S. DOE, 1988) 


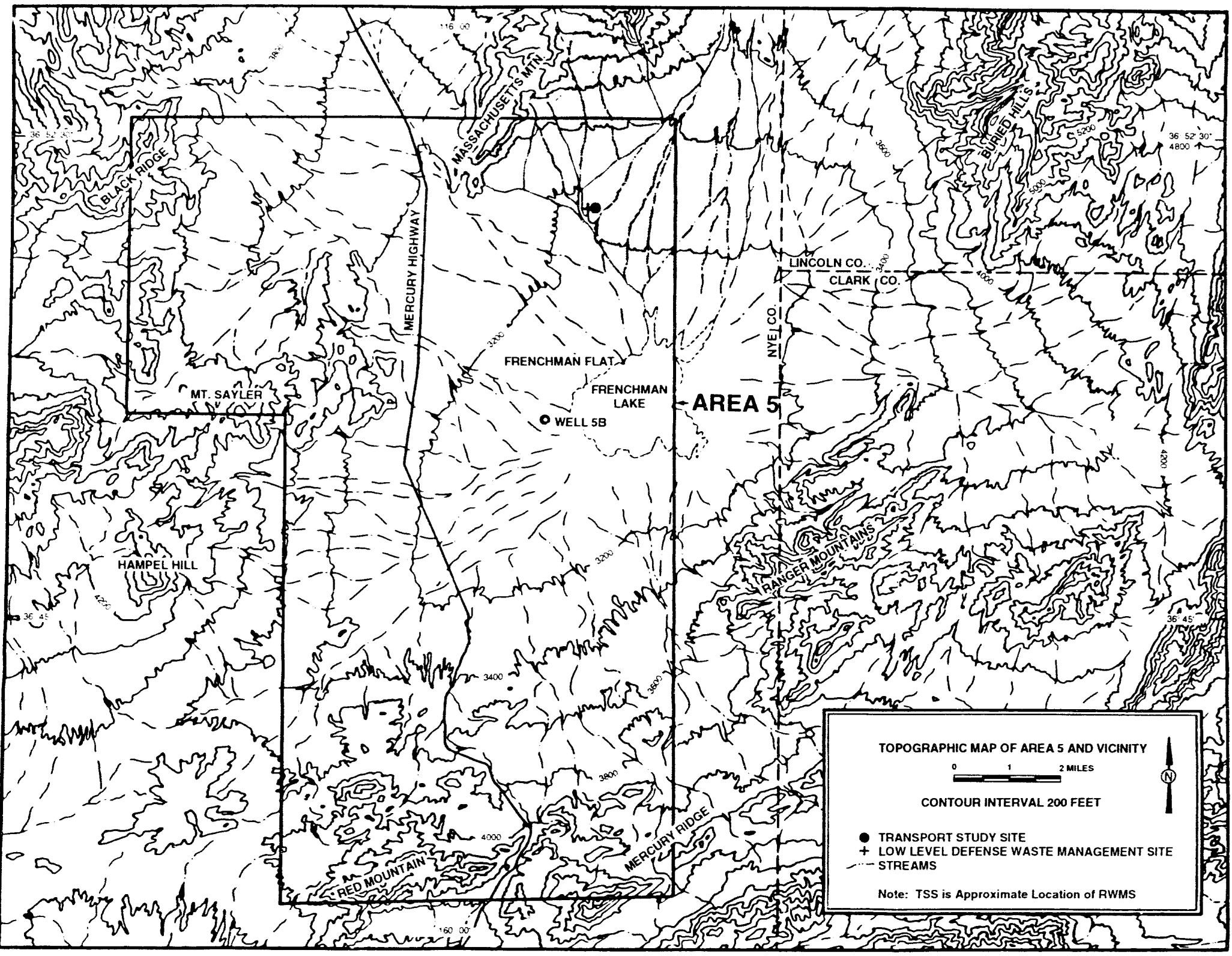

Figure 2-5. Physiographic Features in Vicinity of Frenchman Flat (after Case et al., 1984) 
which also is of marine origin and consists primarily of limestone and dolomite with some interbeds of quartzite, siltstone, and shale. Thickness of this aquifer has been estimated to be approximately 14,000 feet $(4,300$ meters $)$.

Unconformably overlying the marine sedimentary rocks are Tertiary tuffaceous volcanic rocks ranging from Oligocene through early Pliocene age. The sequence of volcanic rocks consists of numerous deposits of tuff derived from hot ash flows (nuée ardentes) that were explosively ejected from volcanos. Upon deposition, each ash flow cooled with the location within the flow affecting cooling rate and resultant mineralogy and rock texture. These volcanic rocks originated from volcanic centers located to the north and to the west of Frenchman Flat. The Tertiary volcanic rocks have an estimated thickness of 1,800 feet (550 meters) and are subdivided into two hydrostratigraphic units (1) the tuff aquitard and (2) the tuff aquifer (Figure 2-6). Both units crop out in the mountains to the north and to the west of Frenchman Flat. The tuff aquitard is characterized by up to 700 feet $(210$ meters) of relatively unfractured nonwelded to welded tuff with interbeds of sandstone, mudstone, and limestone. The tuff aquifer consists of up to 1,100 feet (335 meters) of bedded and fractured welded tuffs.

Sediments that have eroded from the surrounding highlands and aggraded into Frenchman Flat form the fifth hydrostratigraphic unit, which is known as the Valley Fill Unit. The sediments are poorly to moderately cemented alluvial-fan, flood-plain, streambed, talus-slope, slope-wash, and eolian deposits. Grain size and degree of sorting of these sediments depends on the source rock, material composition, distance from the source area, and mode of transport and deposition. This unit is limited in extent to Frenchman Flat and has an estimated thickness of 1,300 feet (400 meters) (Case et al., 1984).

\subsection{Structural Setting}

Frenchman Flat is a structural basin that formed chiefly in the late Pliocene through Quaternary time.

During the Paleozoic Era, many thousands of meters of sedimentary rocks were deposited. The rocks were intruded, folded, and faulted by compressional forces about an east-southeast west-northwest axis during the Mesozoic Era. Additional faulting occurred during the Cenozoic Era in response to extensional tectonics.

The major structural elements in the Frenchman Flat area are the Cane Spring and Rock Valley fault systems (Figure 2-7). A zone of faulting from 8 to 13 kilometers (13 to 21 miles) wide and 60 kilometers (97 miles) long has been identified as the Rock Valley fault system. Quaternary movement along the Rock Valley fault system has been documented (Barnes et al., 1982; Swadley, 1983; Yount et al., 1987; Swadley and Huckins, 1989), and 


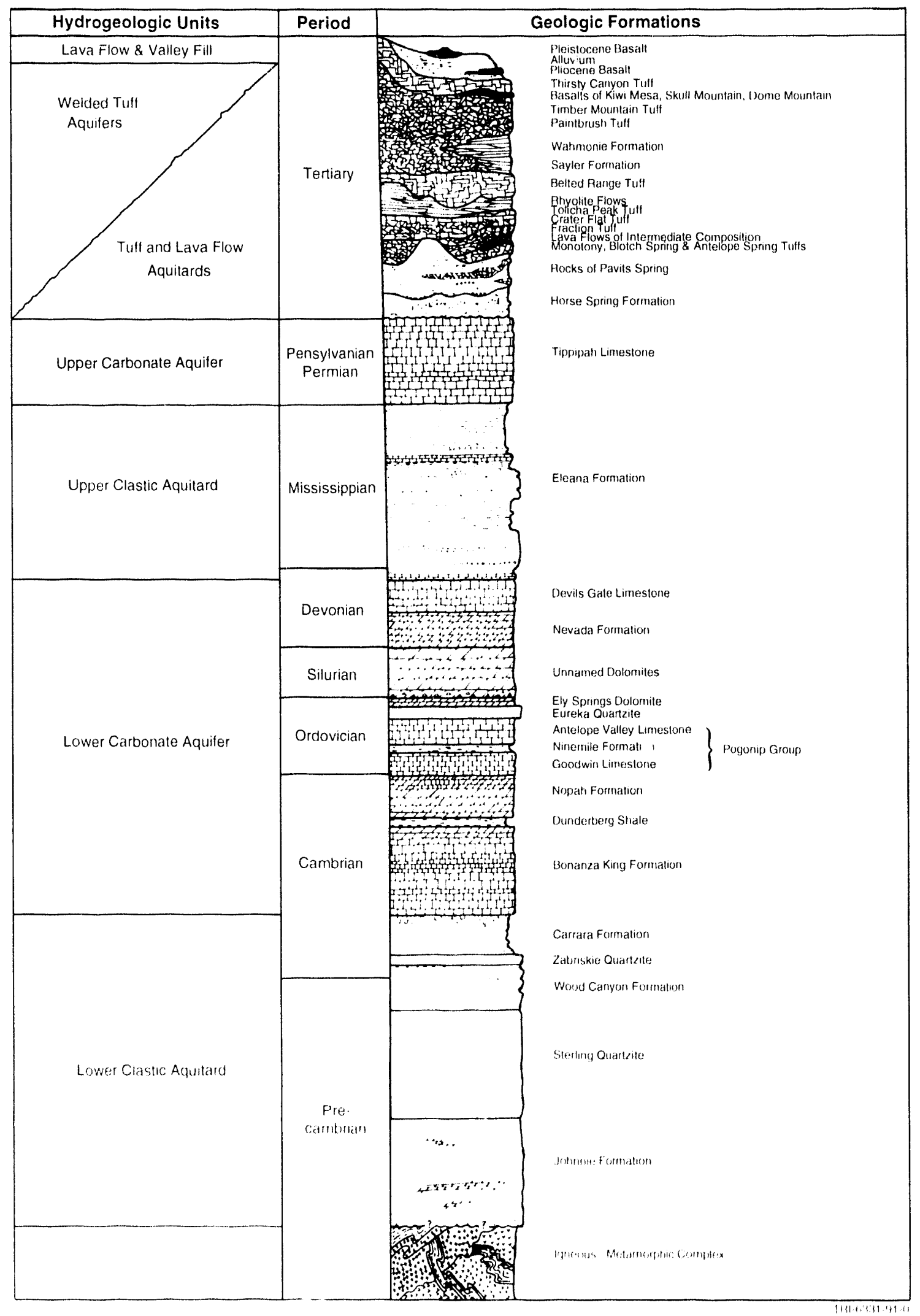

Figure 2-6. General Relationship of Hydrogeologic and Geogeologic Units in the Southern Great Basin (U.S. DOE, 1986a; after Sinnock, 1982) 


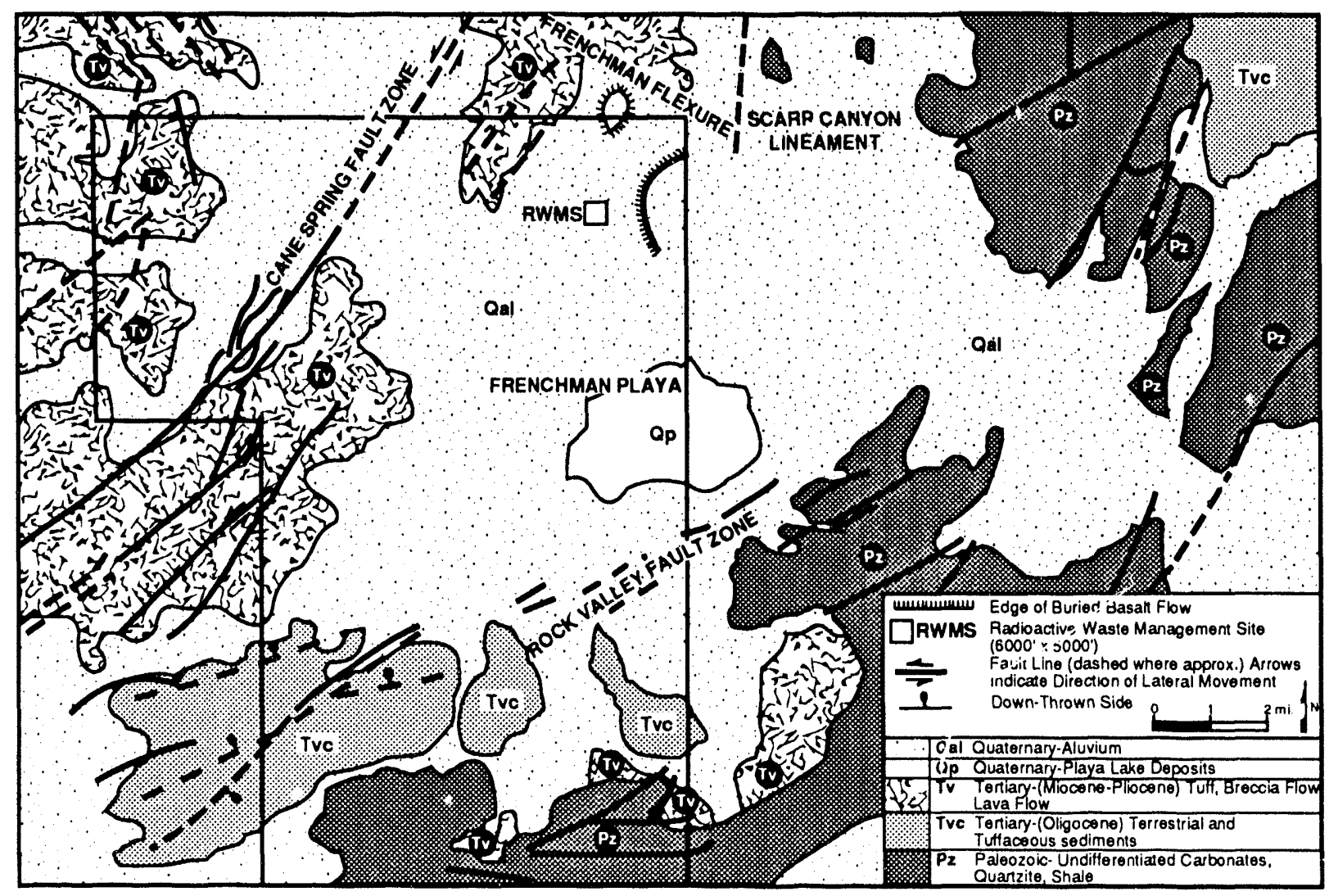

TRI.6331.96.0

Figure 2-7. Map Showing the General Geology and Major Structural Features in Frenchman Flat and Vicinity (modified from Case et al., 1984) 
possible evidence for Holocene(?) movement within Frenchman Flat has been identified by Carr et al. (1967).

The Cane Spring fault zone is located west of Frenchman Playa. Carr et al. (1967) and Dockery (1984) project this fault zone in a northeasterly direction into the Massachusetts Mountains, which are north of the RWMS (Figure 2-7), where this fault zone interacts with north-south trending faults. More than one explanation for the arcuate shapes of faults at this interaction location have been proposed. In order to accommodate this interaction of faults, Carr (1984) proposed right-lateral displacement along the Frenchman Flexure. More recent work based on paleomagnetic data (Hudson, 1992) has identified reorientation of the stress field as a possible mechanism to accommodate the displacements of faults of differing orientations instead of shearing along the Frenchman Flexure. Left-lateral displacement of Tertiary and Quaternary ages have been identified along several faults witiin the Cane Spring fault zone (Poole et al., 1965).

\subsection{Geomorphology}

Geomorphic relationships within Frenchman Flat were established in early to middle Tertiary time by the uplift of the mountain ranges and the subsidence of the basin floor. The relative vertical displacements of adjacent areas resulted in the development of erosional processes in the mountains and depositional processes in the basin. These processes are primarily controlled by climate, topography, and tectonic activity.

The topography of Frenchman Flat can be divided into three categories (1) upland landforms (mountain ranges), (2) piedmont slopes between the uplands and the basin floor, and (3) basin floor (with a playa in the lowest portion). Topography in the uplands can be subdivided into ridge crests, valley bottoms, and intervening hill slopes. The ridge crests generally are rugged and devoid of loose talus material. Valley bottoms range from shallow, straight, steeply sloping gullies and ravines to deep, gently sloping valleys. Intervening hill slopes are comprised of colluvial and alluvial surfaces. These surfaces are cut by numerous gullies and small ravines that expose underlying bedrock.

Piedmont slopes currently exposed at the surface are of Pleistocene and Holocene age and can be subdivided into three zones (1) range-front slopes adjacent to the fronts of mountain ranges, (2) intermediate piedmont slopes, and (3) piedmont slopes adjacent to the playa. Range-front slopes commonly have exposures of older deposits where erosion has developed a ridge-and-ravine type of topography (Bull, 1991). The ridges in this type of topography tend to be rounded and highly degraded, and the ravines are mostly steepsided and V-shaped. Intermediate piedmont slopes include the areas where deposition of sediments derived from the surrounding mountain ranges form alluvial fans, and $t^{1} \mathrm{e}$ merging of drainage systems formed by the incision of gullies and arroyos by erosional processes occur. The GCD location lies within an intermediate slope near the intersection of several alluvial fans. Individual depositional units within the intermediate 
slopes are typically less than a few meters thick. Piedmont slopes nearest the playa are less sedimentologically and structurally complex than the range-front and intermediate piedmont slopes. Age relationships between sedimentary deposits near the playa generally are distinct, and alluvial surfaces are dominated by bar-and-swale topography of low relief.

The basin floor consists of flat-lying playa deposits primarily derived from material washed in during wet conditions or blown in during dry conditions. Deflation also can occur during dry conditions with fine-grained material being blown from the surface of the playa onto the adjacent piedmont slopes.

\subsection{Climate}

Frenchman Flat is located within one of the warmest and driest areas of the United States. Total yearly precipitation ranges from 10 to 13 centimeters ( 4 to 5 inches) at the GCD location (RSN, 1991). Precipitation in the NTS region is associated with two distinct weather patterns. Winter frontal storms associated with Pacific air masses moving from the west coast of California provide about half of the annual precipitation. As the seasons progress toward summer, the air moisture sources change from a western source to a southern source. The southern source consists of air masses from the Gulf of California that give rise to late summer monsoonal thunderstorms, which provide the remainder of the annual precipitation.

Precipitation from late summer thunderstorms produces most of the surface-water runoff that results in erosion and deposition of sediments. The thunderstorms generally produce localized high-intensity precipitation of short duration that often results in flash floods.

Temperatures for Frenchman Flat are similar to those in Yucca Flat where the mean high and low temperatures for the year occur during July and January, respectively. With a strong correlation between altitude and temperature, the overall mean temperatures for Frenchman Flat should be slightly higher than for Yucca Flat, because Frenchman Flat is at a lower altitude than Yucca Flat. The mean daily high temperature for July at Yucca Flat is $96.1^{\circ} \mathrm{F}\left(35.6^{\circ} \mathrm{C}\right)$ and the mean daily low is $47.0^{\circ} \mathrm{F}\left(8.3^{\circ} \mathrm{C}\right)$, and the mean daily high temperature for January is $52.1^{\circ} \mathrm{F}\left(11.2^{\circ} \mathrm{C}\right)$ and the mean low is $20.8^{\circ} \mathrm{F}\left(-6.2^{\circ} \mathrm{C}\right)$ (U.S. DOE, 1988).

Evaporation rate at the GCD location has been estimated to be from 60 to 82 inches/year (152 to 208 centimeters/year) (McCord, 1990).

\subsection{Surface Hydrology}

Frenchman Flat is a topographically closed basin. The majority of recharge occurs at the fronts of the surrounding mountain ranges where runoff from precipitation on the 
mountains flows onto the coarser sands of the piedmont adjacent to the mountains. During intense rainfall, runoff may reach the Frenchman Playa where major recharge to the Valley Fill Aquifer and the Tuff Aquifer may occur. Minor recharge to the Lower Carbonate Aquifer may occur by leakage through the Tuff Aquitard possibly along fault zones.

No perennial bodies of surface water exist in Frenchman Playa. Standing water in the playa occurs only a few days per year in direct response to precipitation in the immediate locality (Price et al., 1993b).

\subsection{Subsurface Hydrology}

The stratigraphic units at Frenchman Flat can be divided into five major hydrostratigraphic units (1) Lower Clastic Aquitard, which consists of Precambrian through middle Cambrian units, (2) the Lower Carbonate Aquifer, (3) Tuff Aquitard, (4) Tuff Aquifer, and (5) Valley Fill Unit. Both the Upper Clastic Aquitard and the Upper Carbonate Aquifer, which are present in other portions of the Southern Great Basin, have not been identified at this location. The following descriptions of these units is primarily based on Case et al. (1984) and Price et al. (1993b).

The Lower Clastic Aquitard is characterized by beds of quartzite with siltstone, shale, and minor carbonate interbeds that range in age from Precambrian to middle Cambrian (Table 2-1). This hydrostratigraphic unit overlies the basement complex of igneous and metamorphic rocks. The thickness of this unit has been estimated at 10,000 feet $(3,000$ meters).

Overlying the Lower Clastic Aquitard is the Lower Carbonate Aquifer, which consists primarily of limestone and dolomite with interbeds of quartzite. This unit is approximately 14,000 feet (4,300 meters) thick and ranges in age from middle Cambrian to Devonian or perhaps lower Mississippian. This aquifer is of regional extent with discharge believed to occur at Ash Meadows in the Amargosa Valley (U.S. DOE, 1986b). Water levels in two wells that penetrate this aquifer have hydraulic heads lower than those in the overlying volcanic units (Case et al., 1984).

Tuffaceous volcanic rocks of Tertiary age unconformably overlie the Lower Carbonate Aquifer. The lower portion of the volcanic sequence, which consists of relatively unfractured nonwelded to welded tuffs with interbeds of sandstone, comprises the Tuff Aquitard. This unit is approximately 2,580 feet ( 787 meters) thick. Overlying this aquitard is the Tuff Aquifer, which consists of approximately 1,100 feet (335 meters) of bedded and fractured welded tuffs. Because of displacement along faults bounding Frenchman Flat during basin formation, the mountains surrounding Frenchman Flat are believed to define the lateral extent of these hydrostratigraphic units. Recharge to the 
Tuff Aquifer is believed to occur by vertical infiltration from the overlying Valley Fill Unit.

The Valley Fill Unit is the saturated portion of the sedimentary sequence deposited on the tuffaceous units. Within Frenchman Flat as a whole, the range in depths to the water table was reported as 518 to 1176 feet (158 to 358 meters) by Winograd and Thordarson (1975) but 213 to 366 meters (700 to 1,200 feet) by Case et al. (1984). Differences in these measurements are primarily dependent on the locations of the measurements. At the GCD location, the depth to the water table is approximately 244 meters ( 800 feet). The elevation of the water table is nearly uniform within the basin, indicating a very low horizontal hydraulic gradient. In the southwestern portion of Frenchman Flat, perched water has been reported above the Valley Fill Unit at depths as shallow as 21 meters (70 feet). Recharge to the Valley Fill Unit primarily occurs at the mountain fronts and possibly at Yucca Playa. Recent work on environmental tracers (Conrad, 1993) suggests that recharge is negligible to nonexistent on the piedmont slopes. 
Table 2-1. Simplified Stratigaphic Column at the GCD Site (adapted from Winograd and Thordarson, 1975 )

\begin{tabular}{||l|l|l||}
\hline $\begin{array}{l}\text { HYDROGEOLOGIC } \\
\text { UNIT }\end{array}$ & EPOCH & PERIOD \\
\hline $\begin{array}{l}\text { Unsaturated Zone } \\
\text { Valley Fill Aquifer }\end{array}$ & $\begin{array}{l}\text { Holocene } \\
\text { Pleistocene } \\
\text { Pliocene }\end{array}$ & $\begin{array}{l}\text { Quaternary and } \\
\text { Tertiary }\end{array}$ \\
\cline { 1 - 2 } Tuff Aquifer & $\begin{array}{l}\text { Pliocene } \\
\text { Miocene }\end{array}$ & $\begin{array}{l}\text { Tertiary } \\
\text { Miocene } \\
\text { Tuff Aquitard }\end{array}$ \\
\hdashline $\begin{array}{l}\text { Lower Carbonate } \\
\text { Aquifer }\end{array}$ & $\begin{array}{l}\text { Permian through } \\
\text { Middle Cabrian }\end{array}$ \\
\hline $\begin{array}{l}\text { Lower Clastic } \\
\text { Aquitard }\end{array}$ & $\begin{array}{l}\text { Middle Cambrian } \\
\text { through Precambrian }\end{array}$ \\
\hline
\end{tabular}

-..- Unconformity 


\subsection{REGULATORY BASIS FOR SCENARIOS}

As stated in Chapter 1, the GCD facility originally was designed to demonstrate the safe disposal of certain types of nuclear waste. If the TRU waste in four of the boreholes is to be left in the boreholes for permanent disposal, one of the environmental regulations with which the GCD facility must comply is the EPA's Environmental Radiation Protection Standards for Management and Disposal of Spent Nuclear Fuel, High-Level and Transuranic Radioactive Wastes--Final Rule 40 CFR Part 191 (U.S. EPA, 1985). Throughout the remainder of this report, this regulation will be referred to as the Standard. The Standard is divided into two subparts. Subpart A specifies performance criteria for the handling and storage of radioactive waste during the operational phase of the disposal facility, and Subpart B specifies performance criteria for specified types of radioactive waste during the postclosure time period of regulatory concern. Subpart B contains three sets of performance criteria and one set of assurance criteria. The performance criteria are described in $\$ 191.13$ Containment Requirements, $\$ 191.15$ Individual Protection Requirements, and $\$ 191.16$ Ground-Water Protection Requirements. Assurance Requirements are listed within \$191.14. Summaries of these requirements can be found in Price et al. (1993a). Demonstrating compliance with the Containment Requirements leads to the necessary development of scenarios, although this development is implied rather than stated.

On July 17, 1987, the United States Court of Appeals, 1st Circuit, vacated the Standard and remanded the regulation to the U.S. EPA for corrective action. The reasons for this action are (1) a discrepancy between the regulatory requirements of the Individual Protection Requirements in the Standard and part C of the Safe Drinking Water Act, (2) the U.S. EPA had not justified the 1,000-year regulatory time frame for the Individual Protection Requirement, and (3) the Ground-Water Protection Requirements were promulgated without sufficient notice for public comment (U.S. EPA, 1993). The other parts of the Standard also were vacated and remanded even though these parts were either unchallenged or upheld by the court. Upon rehearing in September 1987, Subpart A of the Standard was reinstated, but Subpart B was not (U.S. EPA, 1993). The Waste Isolation Pilot Plant Land Withdrawal Act was enacted on October 30, 1992. This Act reinstated all of the Standard except the Individual Protection and Ground-Water Protection Requirements, which were the reasons for the remand (U.S. EPA, 1993). Until the repromulgated Standard (U.S. EPA, 1993) becomes effective, the GCD Performance Assessment Project will use the 1985 version of the Containment Requirements as performance goals for the preliminary performance assessments.

The Containment Requirements establish probabilistic limits on the cumulative amounts of radionuclides that can reach the accessible environment during 10,000 years after decommissioning of the disposal facility. As stated in the Standard, 
(a) Disposal systems for spent nuclear fuel or high-level or transuranic radioactive wastes shall be designed to provide a reasonable expectation, based upon performance assessments, that cumulative releases of radionuclides to the accessible environment for 10,000 years after disposal from all significant processes and events that may affect the disposal system shall meet certain criteria. (U.S. EPA, 1985, p. 38086).

The Standard defines a "performance assessment" as

an analysis that: (1) Identifies the processes and events that might affect the disposal system; (2) examines the effects of these processes and events on the performance of the disposal system; and (3) estimates the cumulative releases of radionuclides, considering the associated uncertainties, caused by all significant processes and events. (U.S. EPA, 1985, p. 38086).

Although not stated in the Containment Requirements or elsewhere in the Standard, combinations of "significant events and processes" also may affect the performance of the disposal system. Any performance assessment that does not include the analyses of combinations of events and processes is inherently incomplete unless some of these combinations can be excluded from consideration without significantly affecting the performance measure based on criteria compatible with the intent of the regulation. In generic performance assessments, combinations of processes and events generally are referred to as "scenarios", although a variety of specific definitions exist. The term scenario is used once in the Standard, in Appendix B of Subpart B, but is not defined.

No guidance is provided in the Standard on how to identify significant processes and events for inclusion in performance assessments or how to address the possibility of more than one process or event occurring and affecting the same disposal system during the same time period. 


\subsection{DESCRIPTION OF SCENARIO-DEVELOPMENT PROCEDURE USED FOR THE GREATER CONFINEMENT DISPOSAL SYSTEM}

An early attempt at developing scenarios for use in site-specific performance assessments for the GCD Project provided a basis for the selection of the scenarios used in a preliminary performance assessment (PPA) by the SRA Department (Price et al., $1993 \mathrm{a}, \mathrm{b}, \mathrm{c})$. Because this early work on scenario development did not use a structured procedure in the identification and construction of scenarios, questions of both the completeness and reproducability of the scenarios have arisen. To address these questions in later iterations of the performance assessments for the GCD disposal system, the issue of scenario development has been revisited through the implementation of a scenario-development procedure that was devised to specifically address the Containment Requirements of the Standard.

\subsection{Previous Approaches to Scenario Development for GCD Location}

Preliminary scenario development for the GCD location was first addressed by EG\&G Idaho, Inc. The results of this preliminary scenario development were used by SRA Department to identify a limited number of scenarios for inclusion in a preliminary performance assessment of the GCD location.

\subsubsection{Original Scenario-Development Effort for GCD Location}

The earliest work on scenario development for the GCD location is described in Hertzler and Atwood (1989) and Hertzler (1989). In Hertzler and Atwood (1989), 49 initiating events and processes were identified as potentially contributing to the release of radionuclides from a disposal facility with 26 events and processes naturally occurring, 13 human induced, and 10 waste or repository induced. These events and processes were screened on the basis of physical reasonableness, likelihood of occurrence, and consequence. Scenarios were then identified by examining possible release or transport mechanisms resulting from each initiating event or process.

A total of 72 "release scenarios" were identified and subsequently screened on the basis of credibility, probability, and release significance for inclusion in the performance assessment of the GCD. Of the scenarios examined, 9 were concluded to be credible at the GCD, 27 were identified as insignificant for the purpose of performance assessment, 22 remained to be evaluated, 6 required transport modeling that had not been completed, 15 required additional study, and the remainder were determined to involve inherently unknown events and processes. Some of the events and processes were found to have several consequences, and not all of the multiple release events and processes were identified. In an update to this preliminary analysis, Hertzler (1989) identified 8 scenarios for modeling in performance assessment, 36 as insignificant, with 21 remaining to be screened. This update also did not attempt to address the topic of multiple release events 
and processes, and no plans were presented on how this topic would be addressed in the future.

Although this preliminary scenario work was helpful in identifying scenarios for the PPA, as described in Section 4.1.2, several major problems exist with attempting to use this early work to address the specific needs of the Containment Requirements. The first problem is that no definition was provided for the term "scenario". At times in these reports, "scenario" seems to be interchangeable with the words "event" and "process", although "release scenario" may be restricted to events and processes that result in the escape of radionuclides from the GCD facility. Other problems arise from the fact that no well-defined, scenario-development methodology was used. The lack of such a methodology makes technical review and duplication of results extremely difficult, and the issues of scenario completeness and scenario probabilities are difficult to impossible to address.

\subsubsection{Scenario Selection for a Preliminary Performance Assessment}

The SRA Department used the results of this scenario-development effort to identify a limited number of scenarios for analysis in a PPA. As a first step toward reaching a managable number of scenarios, the results of screening the events and processes were refined until 12 initiating events and processes remained (Price et al., 1993a,b). With 12 events and processes having survived screening and refinement, 4,096 possible combinations could be developed. Because of the limitations in time and funding for the PPA, only three scenarios (each represented by a single event or process) were identified and analyzed in addition to undisturbed conditions.

Of the 12 events and processes considered, 5 were naturally occurring, 6 human-induced, and 1 waste-induced. Because the Standard requires the inclusion of human intrusion in performance assessments, drilling into waste was considered to be representative of human-intrusion activities. The remaining 6 events and processes were subjectively ranked (from highest to lowest) on probability of occurrence and consequence, with climatic change and land erosion having the highest combined rankings and completing the 3 scenarios for the PPA. As part of the implementation of the performanceassessment methodology, additional scenarios can be included in later iterations of the performance assessments as merited as additional data and information become available.

\subsection{Revised Scenario Development for the GCD Location}

To address the performance criteria of the Standard, the scenarios should be comprehensive and mutually exclusive. For review purposes, the procedure used to develop the scenarios should be trackable and preferably reproducible. The preliminary work on scenario development resulted in the identification of a small fraction of a potentially large number of complexly defined scenarios that could not be shown to be 
comprehensive and mutually exclusive. The procedure used to identify the scenarios was difficult to follow, and the implementation of the procedure is unlikely to be reproducible by anyone independent of this specific task.

To remedy the limitations of the original attempt at scenario development for the GCD location, the SRA Department decided to revisit the task of scenario development by implementing a structured scenario-development procedure. The Nuclear Energy Agency (1992) summarized several procedures for addressing the issue of scenarios identification for performance assessments. One of the systematic procedures described (Cranwell et al., 1990) was developed by the Waste Management Systems Division (now the SRA Department) of Sandia National Laboratories to specifically address performance assessments and regulatory compliance with the Standard. Development of the procedure was funded by the U.S. Nuclear Regulatory Commission. The application of this procedure to the GCD provides a comprehensive set of mutually exclusive scenarios that are amenable to both consequence analyses and probability assignment. This procedure, or a modification of the procedure, has been used in a joint exercise in scenario development by the Swedish Nuclear Power Inspectorate and the Swedish Nuclear Fuel and Waste Management Company (Andersson et al., 1989), the Canadian Nuclear Fuel Waste Management Program (Stephens and Goodwin, 1990), and Sandia National Laboratories for the Waste Isolation Pilot Plant (Guzowski, 1990).

As a starting point in developing the procedure, Cranwell et al. (1990) defined scenarios as sets of naturally occurring, human-induced, and waste- and repository-induced events and processes that represent realistic future changes to the repository, geologic, and hydrologic systems that may affect the escape and transport of radionuclides from the disposal facility. The procedure to identify scenarios defined in this way consists of five steps: (1) the compilation, adoption, or adaptation of a "comprehensive" list of events and processes that could affect the performance of the disposal system, (2) classification of the events and processes to aid in addressing completeness arguments, (3) screening of the events and processes to identify those that can be eliminated from consideration in the performance assessment without affecting the determination of regulatory compliance, (4) development of comprehensive and mutually exclusive scenarios by combining the events and processes that remain after screening, and (5) screening scenarios to identify those scenarios that will have no bearing on the performance measure, so that consequencemodeling efforts can be focused on those scenarios that do.

\subsubsection{Step 1: Identifying Events and Processes}

The initial list of events and processes in this procedure can be either compiled as an original list, adopted from one or more existing sources, or adapted from one or more existing sources. Whichever approach is taken, the question as to whether the list is comprehensive must be addressed. 


\subsubsection{Initial List of Events and Processes}

An initial list of events and processes for the first step of the procedure was provided in Cranwell et al. (1990) (Table 4-1). This list was derived from events and processes identified by a panel of experts with diverse professional backgrounds that met in 1976 and again in 1977 under the auspices of the U.S. Nuclear Regulatory Commission. The goal of this panel was to identify those events and processes that could affect the escape of radionuclides from the engineered facility and transport of radionuclides within the disposal system rather than to identify every imaginable event and process that could occur. This list was not intended to be the definitive listing of events and processes but was intended to serve as a starting point for modification on a site-specific or performance-measure basis as needed.

The distinction between an event and a process is dependent on the time interval over which a phenomenon occurs. From a practical point of view, an event occurs over a relatively short time interval, and a process occurs over a much longer relative time interval. In identifying events and processes for the GCD performance assessment, phenomena that occur instantaneously or within a relatively short time interval are considered to be events, and phenomena that occur during a significant portion of the 10,000 years of regulatory concern are considered to be processes.

\subsubsection{Modified Initial List of Features, Events, and Processes}

In developing scenarios, questions about the completeness of the initial set of events and processes are common. Table 4-2 lists sources of other lists of events and processes in addition to features developed for use in site evaluation. "Feature" refers to something present within the disposal system having physical dimensions and form (e.g., a fault zone). The requirements of the Standard were not the motivation for the development of most of these lists, and as a result, some of these lists are extensive. Appendix B contains a listing from each of these sources. To address the concerns about the completeness of the initial list, the lists from all of the references listed in Table 4-2 were considered to comprise a single list consisting of 761 features, events, and processes (FEPs). With the FEPs primarily reduced in number by the elimination of duplications of FEPs and repetition of FEPs under slightly different names, this newly developed starting list contains 205 FEPs and is located in Appendix C.

In the Cranwell et al. (1990) procedure, only events and processes are considered. Some of the other lists contain entries that cannot be classified as either events or processes, hence the use of the broader term FEPs. In the following discussion about the scenariodevelopment procedure, events and processes are referred to when discussing the steps of the procedure. FEPs is used when discussing the application of the procedure to the GCD disposal system because of the consideration of the expanded list of phenomena in the GCD performance assessment. 
Table 4-1. Potentially Disruptive Events and Processes (after Cranwell et al., 1990)

\begin{tabular}{|c|}
\hline Natural Events and Processes \\
\hline$\frac{\text { Celestial Bodies }}{\text { Meteorite Impact }}$ \\
\hline $\begin{array}{l}\text { Surficial Events and Processes } \\
\text { Erosion/Sedimentation } \\
\text { Glaciation } \\
\text { Pluvial Periods } \\
\text { Sea-Level Variations } \\
\text { Hurricanes } \\
\text { Seiches } \\
\text { Tsunamis } \\
\text { Regional Subsidence or Uplift } \\
\text { Mass Wasting } \\
\text { Flooding }\end{array}$ \\
\hline $\begin{array}{l}\text { Subsurface Events and Processes } \\
\text { Diapirism } \\
\text { Seismic Activity } \\
\text { Volcanic Activity } \\
\text { Magmatic Activity } \\
\text { Formation of Dissolution Cavities } \\
\text { Formation of Interconnected Fracture Systems } \\
\text { Faulting }\end{array}$ \\
\hline Human-Induced Events and Processes \\
\hline $\begin{array}{l}\text { Inadvertent Intrusions } \\
\text { Explosions } \\
\text { Drilling } \\
\text { Mining } \\
\text { Injection Wells } \\
\text { Withdrawal Wells }\end{array}$ \\
\hline $\begin{array}{l}\frac{\text { Hydrologic Stresses }}{\text { Irrigation }} \\
\text { Damming of Streams or Rivers }\end{array}$ \\
\hline Waste- and Repository-Induced Events and Processes \\
\hline $\begin{array}{l}\text { Subsidence and Caving } \\
\text { Shaft and Borehole Seal Degradation } \\
\text { Thermally Induced Stress/Fracturing in Host Rock } \\
\text { Excavation Induced Stress/Fracturing in Host Rock }\end{array}$ \\
\hline
\end{tabular}


Table 4-2. Sources of Lists of Events and Processes Used to Develop the GCD Master List

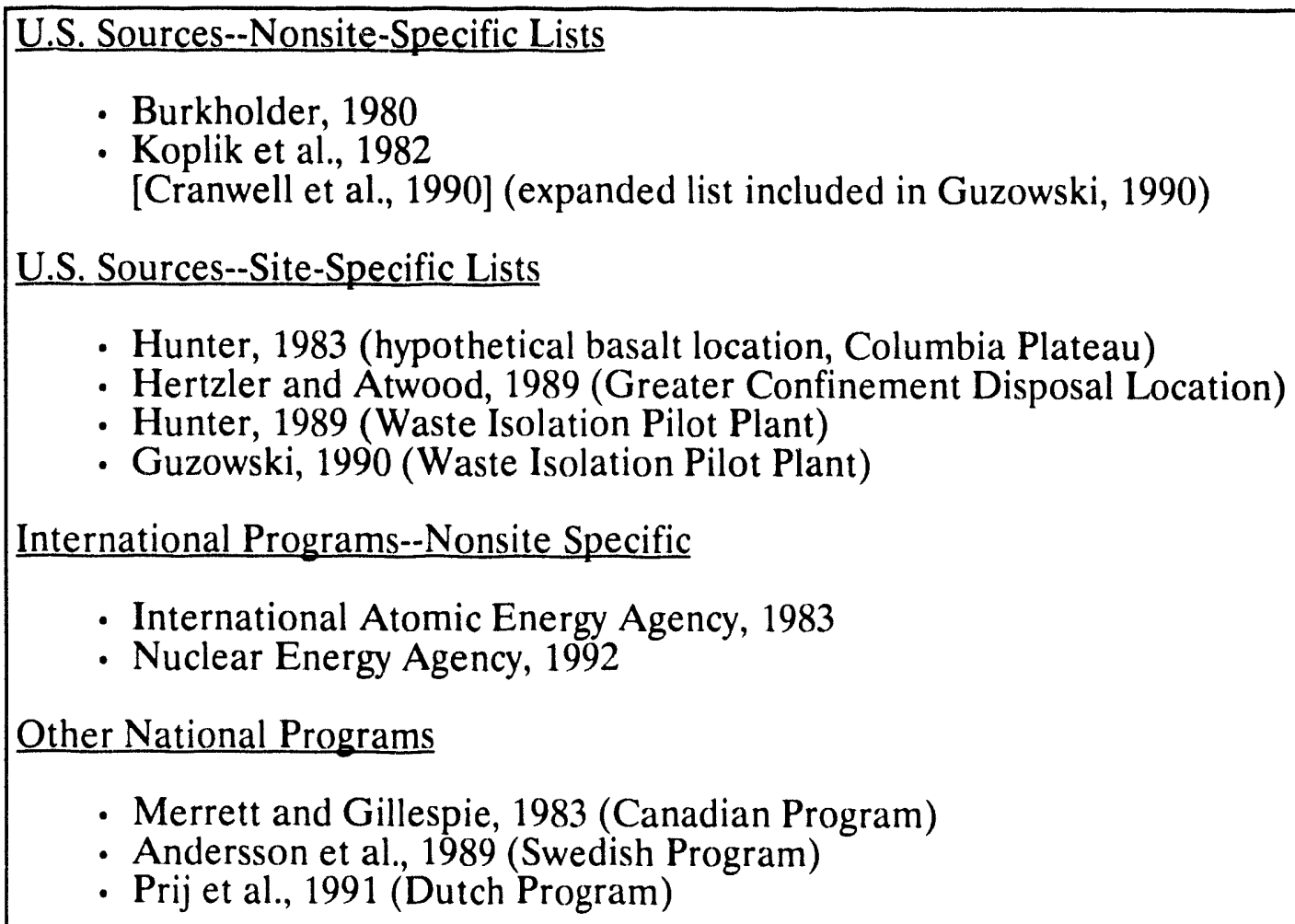

- Hunter, 1983 (hypothetical basalt location, Columbia Plateau)

- Hertzler and Atwood, 1989 (Greater Confinement Disposal Location)

- Hunter, 1989 (Waste Isolation Pilot Plant)

- Guzowski, 1990 (Waste Isolation Pilot Plant)

International Programs--Nonsite Specific

- International Atomic Energy Agency, 1983

- Nuclear Energy Agency, 1992

Other National Programs

- Merrett and Gillespie, 1983 (Canadian Program)

- Andersson et al., 1989 (Swedish Program)

- Prij et al., 1991 (Dutch Program) 


\subsubsection{Step 2: Classifying Events and Processes}

The second step of the procedure classifies the events and processes in the initial list to assist in organizing the events and processes, to assist in completeness arguments, and to provide some insights into what needs to be included when developing conceptual models of the disposal system. A variety of possible classification schemes are possible. The scheme used in Table 4-1 represents a reasonable level of detail. Adaption or adoption of an existing list is likely to have this step already completed, which generally is the case for this task in which lists of previously classified FEPs were adopted.

For the summary list compiled in Step 1 for the GCD scenario development, the basic classification schemes used in the original lists (Appendix B) have been retained with redundancies removed. Some reclassifications of FEPs were made.

\subsubsection{Step 3: Screening Events and Processes}

In the third step of this procedure, the events and processes are screened to identify those that are not pertinent to performance assessments of the particular disposal system being evaluated. The product of this step is a list of events and processes the combinations of which are assumed to define all possible future states of the disposal system.

\subsubsection{Screening Criteria of the Basic Procedure}

Cranwell et al. (1990) listed three criteria for screening the events and processes in their initial list. The criteria are more fully explained in Guzowski (1990) and Guzowski and Helton (1991). These screening criteria are probability of occurrence, physical reasonableness, and consequence.

Probability of occurrence is the first criterion discussed. According to Appendix B of the Standard, events and processes that are estimated to have less than one chance in 10,000 of occurring in 10,000 years do not have to be included in performance assessments regardless of the radionuclide releases to the accessible environment that would result from their occurrence. A discussion of four techniques for estimating probabilities of occurrence is included in Guzowski (1991). An impact of a large meteorite into a repository is an example of an event that can be excluded from consideration in scenario development because of a low probability of occurrence (see Cranwell et al., 1990). The second screening criterion is physical reasonableness. Physical reasonableness is a subjective judgment based on logical arguments using available data and information, and possibly calculations, to support a conclusion of whether or not conditions can exist within the period of regulatory concern that will result in the occurrence of a particular event or process of sufficient magnitude to affect disposal-system performance. An example of the use of physical reasonableness as a screening criterion is presented in Guzowski and Helton (1991) with respect to igneous intrusion at or near the Waste Isolation Pilot Plant 
(WIPP) in southeastern New Mexico. Within the sedimentary basin in which the proposed WIPP is located, a single dike or en-echelon series of dikes has been identified with emplacement dated at approximately 30 million years ago. With no additional igneous activity for 30 million years after dike emplacement, changes in the geologic setting that would result in igneous activity within the next 10,000 years were screened out from consideration, because such large-scale changes in geologic processes within a relatively short time period were considered to be physically unreasonable in light of the long-term tectonic stability of the region and the lack of evidence to suggest that conditions will change within the time frame of regulatory concern. The third screening criterion is consequence, which at this stage of scenario development refers to whether the event or process either alone or in combination with other phenomena affects the performance of the disposal system. Caution must be used in order to consider possible consequences caused by a particular event or process in combination with other events or processes. Simplified conceptual models of the disposal system and simplified mathematical models can be used to determine whether an event or process will alter the ground-water flow system or possible flow paths from the underground facility to the accessible environment. Cranwell et al. (1990) provide examples of modeling being used to demonstrate how the occurrence of individual events could affect ground-water flow patterns.

\subsubsection{Modifications to the Basic Screening Criteria}

Certain screening criteria were implied in Cranwell et al. (1990) but not formally stated. These additional criteria are based on regulatory restrictions and the recognition of basecase (undisturbed) conditions. The Standard restricts performance assessments to the postclosure time frame, limits human intrusion to inadventent events, limits the severity of human-intrusion events at the repository location, and eliminates the need to include surface transport of radionuclides and the biological pathways-to-man by not considering dose-to-man as a performance criterion. Base-case conditions are those naturally occurring and repository- and waste-induced conditions that are certain to occur during the period of regulatory concern after the disposal facility is sealed. Base-case conditions are discussed in more detail in the section of this report describing the base-case scenario (Section 4.2.4.2).

With the inclusion of lists of FEPs from other sources, additional screening criteria need to be considered because of the broader scope used in developing these lists. Whereas the list in Cranwell et al. (1990) was in a sense prescreened by the originating panel of experts based on the goal of identifying events and processes that could affect the escape and transport of radionuclides and the anticipated regualtory limitations on what needed to be considered, at least some of the other lists were developed with a less restrictive mandate. The resulting lists contain entries that cannot be defined as events and processes but instead include parameter names, features of conceptual models, and responses of the disposal system to the occurrence of events and processes. In addition, 
some of the entries are dependent on specific geologic settings, disposal facilities, types of waste and waste form, and a particular type of site analysis being performed.

Table 4-3 is a summary of the criteria used to screen the master list of features, events, and processes for the GCD scenario development.

Although quantitative screening criteria tend to be preferable to qualitative criteria, both the nature of the FEPs and the availability of data and information will determine how screening can proceed. Because data bases and site characterization for any location are likely to be incomplete, qualitative judgments using interpretations based on geological field relationships, natural analogs, and geographical location will be required. In general, screening decisions based on qualitative judgments supported by strong logical arguments are as justifiable as screening decisions for events and processes based on quantitative values derived from sufficiently detailed data bases and are more justifiable than quantitative decisions based on insufficient data bases.

The product of this screening procedure is the identification of those events and processes that, either alone or in combination with other events and processes, potentially could have an adverse impact on the performance of the disposal system being evaluated. Because only those events and processes that have the potential for compromising the performance of the disposal system are retained for scenario development, the performance assessments are conservative in their assessment of the disposal system's performance (see Section 4.2.4).

\subsubsection{Results of Screening for GCD Location}

Screening of the compiled list of 205 FEPs identified 4 events and processes for retention for scenario development pending rescreening in the next iteration of scenario development based on data and information not currently available. A listing of the 205 FEPs, the screening criterion used for each FEP, their disposition for scenario development, and a discussion of the rationale behind the screening decisions are contained in Appendix D. Based on the original lists of FEPs, these retained events are (1) exploratory drilling for resources, (2) drilling of withdrawal or injection wells, (3) subsidence or caving, and (4) irrigation. These events and their original classifications are listed in Table 4-4. For the purpose of scenario development and probability estimation, the definitions of these events are overly broad. For example, no location is specified for exploratory drilling for resources. This lack of specified location, even on a regional or local scale, can be addressed through modeling by selecting different drilling locations for each computer run. The vast majority of these locations will result in no consequences because of the limited radial extent of radionuclide migration from each borehole. A more efficient approach at this stage of scenario development is to specify where drilling will result in consequences to disposal-system performance. 
Table 4-3. Criteria for Screening Events and Processes

Original Screening Criteria In Cranwell et al. (1990)

- Probability of occurrence

- Consequence

- Physical reasonableness

Implied Screening Criteria In Cranwell et al. (1990)

- Regulatory restrictions for performance assessments

-deal with postclosure conditions

-inadvertent human intrusion only

-limits severity of human-intrusion events at the site

-eliminates surface transport and biological pathways to humans

- Base-case condition

Additional Screening Criteria For GCD Analysis

- Part of the conceptual model

- Response of the disposal system to an event or process

- Parameter name

- Applicability to

-geologic setting

-disposal facility

-type of waste/waste form

-analysis

- "Event" or "process" not adequately defined

Table 4-4. Events Remaining After Screening

Human-Induced FEPs

Postclosure Surface Activities

- Irrigation

Postclosure Subsurface Activities

- Exploratory Drilling For Resources

- Drilling Of Withdrawal/Injection Wells

Waste- And Repository-Induced FEPs

Mechanical FEPs

- Subsidence/Caving 
For scenario development, the retained events are redefined based on the assumption that significant concentrations radionuclides are limited to the original boreholes. The four events are (1) exploratory drilling penetrates a GCD borehole, (2) drilling of a withdrawal or injection well penetrates a GCD borehole, (3) subsidence or caving occurs within the RWMS, and (4) irrigation occurs at the RWMS. These four events and their original classifications are listed in Table 4-5.

\subsubsection{Step 4: Constructing Scenarios}

The goal of this step of the scenario-development procedure is to construct scenarios by combining the events and processes that survive the screening process. To determine compliance with the Containment Requirements, a complementary cumulative distribution function (CCDF) will be constructed using the appropriate cumulative radionuclide releases and probability of occurrence for each scenario. The scenarios used in this construction should be comprehensive so that the sum of the scenario probabilities (including the base-case scenario) will be 1 , and mutually exclusive so that probability and cumulative-release values can be unambiguously assigned to each scenario.

To address the question of comprehensiveness of the scenarios, Cranwell et al. (1990) proposed that the combinations of events and processes that survived screening define all possible future states of the disposal system. This approach is conservative in two ways. The first conservatism is based on scenarios, except for the base-case scenario, being composed of events and processes that are potentially disruptive to the performance of the disposal system. The expression "potentially disruptive" is used because of the uncertainties associated with events and processes. In a probabilistic analysis, a range of parameter values, which represent the uncertainty in that parameter for a particular set of site-specific environmental conditions, is sampled. Not all of the values may enhance the transport of radionuclides from the disposal facility or along the travel path to the accessible environment. The second conservatism is that the sum of the scenario probabilities is 1 . This assumption results in the probability of each scenario being larger than it would be if all events and processes or processes having no potential effect on performance were included in scenario construction. The more events and processes that are included in scenario development, the more scenarios that can be constructed, and the lower the probability of each individual scenario (see Section 4.2.4.1).

\subsubsection{Method of Scenario Construction in Basic Procedure}

A logic diagram is used to construct scenarios. Figure 4-1 is an example of a logic diagram for two hypothetical phenomena that primarily affect the release of radionuclides from the engineered disposal facility and three phenomena that primarily affect radionuclide transport toward the accessible environment. Although a logic diagram looks like a conventional event tree, the sequence of events across the top of the logic diagram implies no temporal relationship, whereas such a relationship is a requirement of 
Table 4-5. Events Used for Scenario Developmment

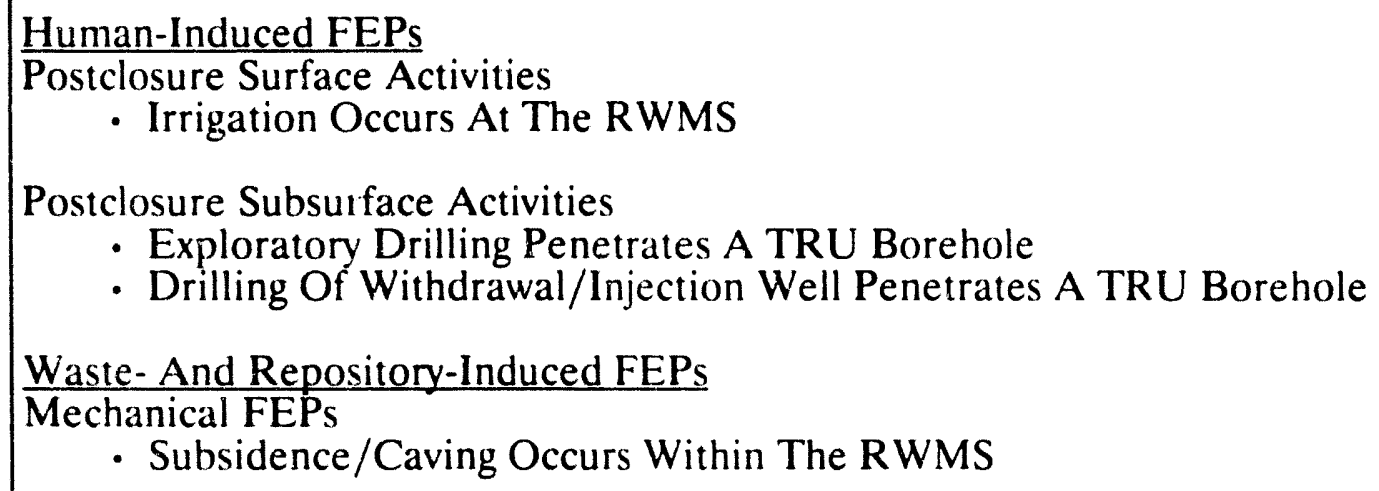

an event tree. At each junction within the logic diagram, a yes/no decision is made as to whether the corresponding event or process across the top of the diagram is added to the scenario. This procedure develops all possible combinations of events and processes with the number of scenarios equal to $2^{n}$, where $n$ is the number of events and processes included in the diagram. Each scenario is a unique combination of events and processes and includes events and processes that occur ("yes" branch) and those that do not occur ("no" branch). Whereas the notation for scenarios in Figure 4-1 has been simplified by omitting the events and processes that do not occur, the complete notation is used in Figure 4-2. The inclusion of the nonoccurring events and processes in each scenario is essential in determining scenario probabilities. By including probabilities for each step (both "yes" and "no") of each pathway through the logic diagram (Figure 4-3), the sum of the scenario probabilities will equal 1.

A concern commonly expressed about the use of logic diagrams to determine scenario probabilities is the capability of including conditional probabilities instead of or in addition to independent probabilities in the diagram. If conditional probabilities can be determined, these values can be entered into the logic diagram without affecting the sum of the scenario probabilities. For example, the independent probability of R2 occurring in Figure $4-3$ is 0.20 (the "yes" leg at Branch 1). If the probability of $R 2$ is conditional on the occurrence of $\mathrm{R} 1$. and the probability of $\mathrm{R} 2$ is 0.05 when $\mathrm{R} 1$ occurs, the probability values entered at Branch 2 would be 0.95 for the "No" leg and 0.05 for the "Yes" leg. Conditional probabilities hetween more than two events and processes can make the assignment of probabilities complicated, although not impossible. As long as the sum of the probabilities at each branch equals 1 , the calculated scenario probabilities within the logic diagram are internally consistent, and the sum of the scenario probabilities will be 1 . 


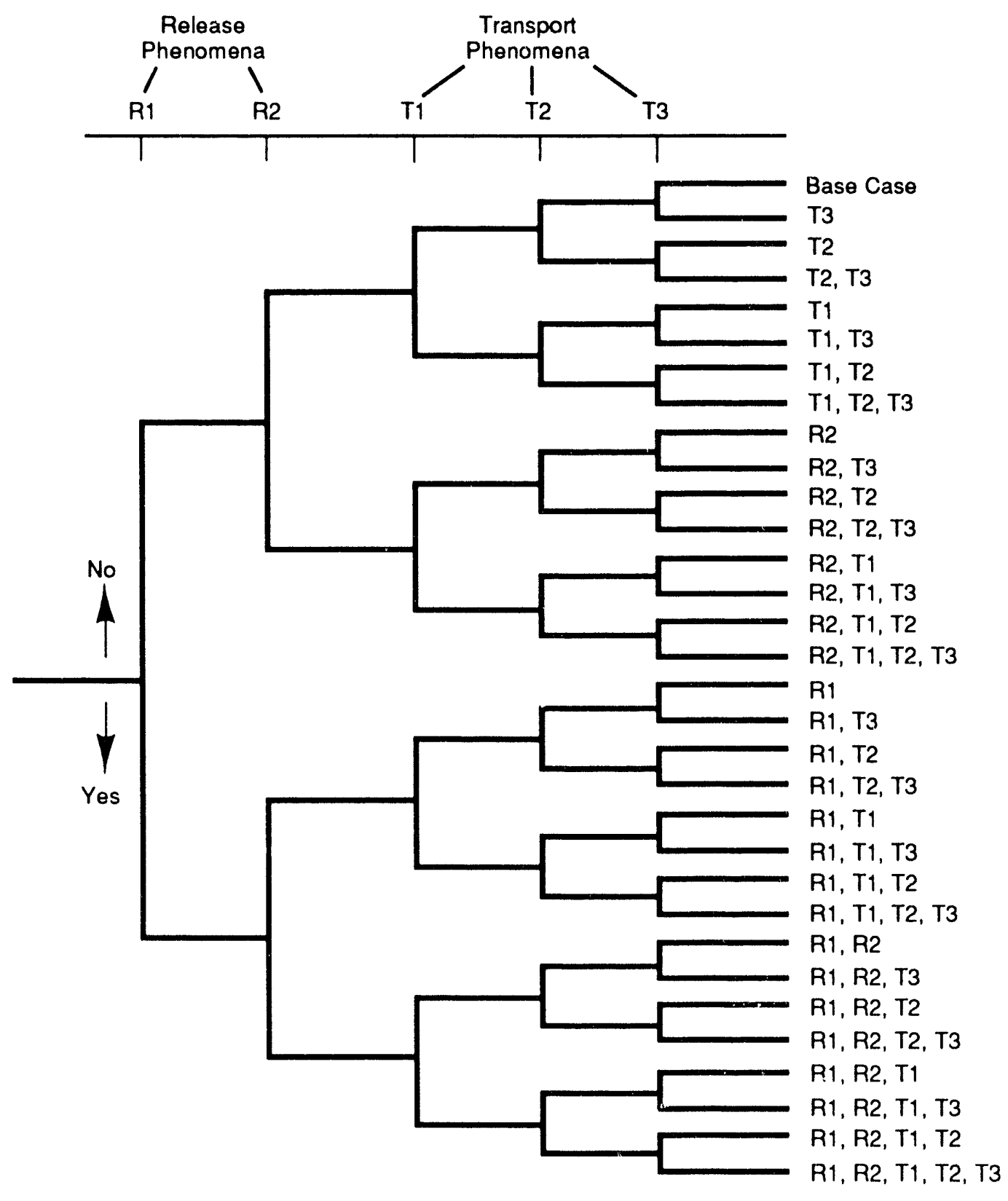

TRI-6342-222.1

Figure 4-1. Demonstration Logic Diagram for the Construction of Scenarios for Hypothetical Events and Processes (Guzowski, 1990) 


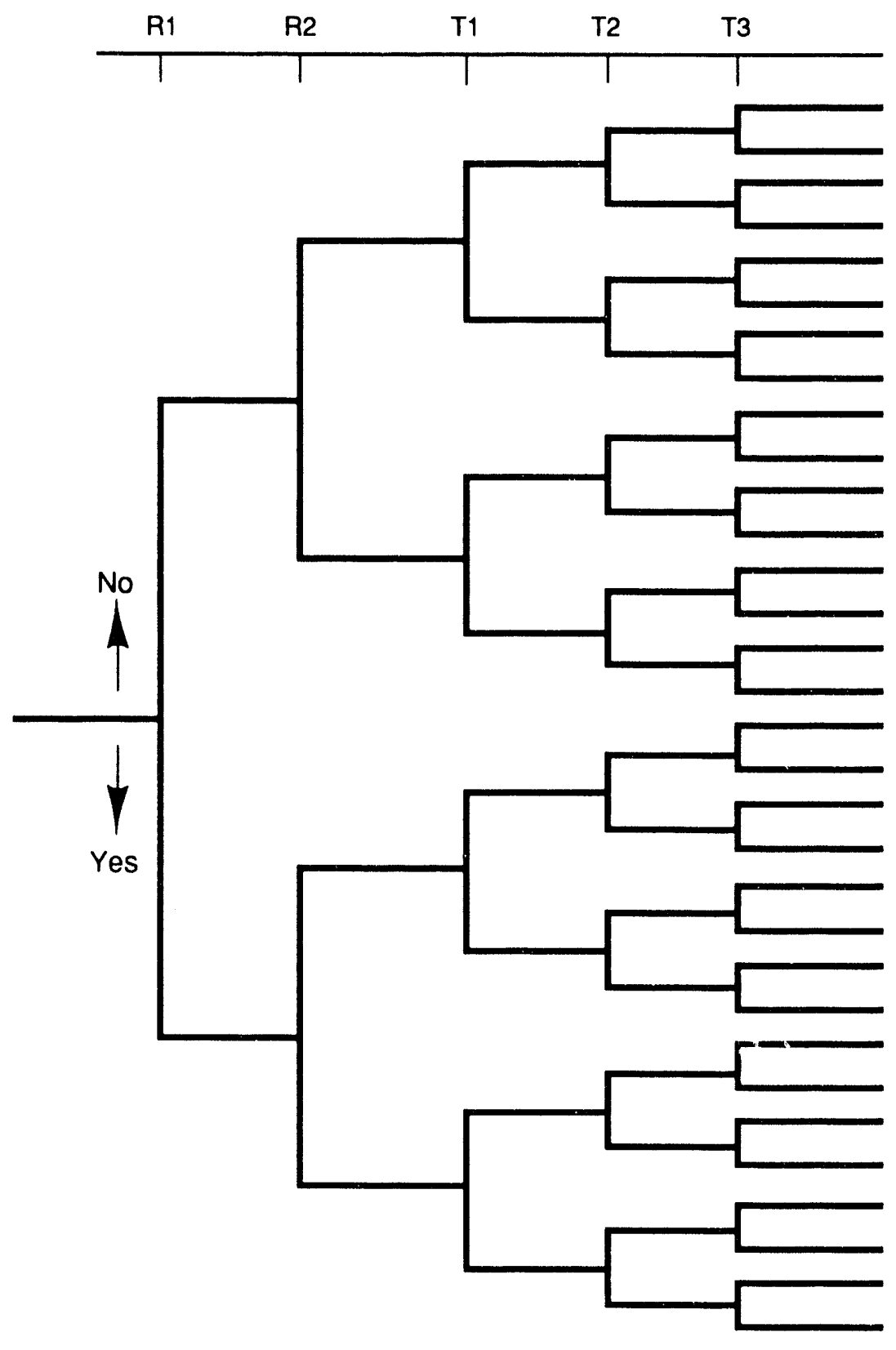

$\overline{\mathrm{R}} 1, \overline{\mathrm{R} 2}, \overline{\mathrm{T} 1}, \overline{\mathrm{T} 2}, \overline{\mathrm{T} 3}$ $\overline{\mathrm{R}} 1, \overline{\mathrm{R} 2}, \overline{\mathrm{T} 1}, \overline{\mathrm{T}} 2, \overline{\mathrm{T}} 3$ $\bar{R} 1, \overline{R 2}, \bar{T} 1, T 2, \bar{T} 3$ $\overline{\mathrm{R} 1}, \overline{\mathrm{R} 2}, \overline{\mathrm{T} 1}, \mathrm{~T} 2, \mathrm{~T} 3$ $\overline{\mathrm{R}} 1, \overline{\mathrm{R} 2}, \mathrm{~T} 1, \overline{\mathrm{T} 2}, \overline{\mathrm{T}} 3$ $\overline{\mathrm{R} 1}, \overline{\mathrm{R} 2}, \mathrm{~T} 1, \overline{\mathrm{T} 2}, \mathrm{~T} 3$ $\overline{\mathrm{R}} 1, \overline{\mathrm{R} 2}, \mathrm{~T} 1, \mathrm{~T} 2, \overline{\mathrm{T}} 3$ $\overline{\mathrm{R} 1}, \overline{\mathrm{R} 2}, \mathrm{~T} 1, \mathrm{~T} 2, \mathrm{~T} 3$ $\overline{\mathrm{R} 1}, \mathrm{R} 2, \overline{\mathrm{T} 1}, \overline{\mathrm{T} 2}, \overline{\mathrm{T} 3}$ $\overline{\mathrm{R} 1}, \mathrm{R} 2, \overline{\mathrm{T} 1}, \overline{\mathrm{T}} 2, \mathrm{~T} 3$ $\overline{\mathrm{R} 1}, \mathrm{R} 2, \overline{\mathrm{T} 1}, \mathrm{~T} 2, \overline{\mathrm{T}} 3$ $\overline{\mathrm{R} 1}, \mathrm{R} 2, \overline{\mathrm{T} 1}, \mathrm{~T} 2, \mathrm{~T} 3$ $\overline{\mathrm{R}} 1, \mathrm{R} 2, \mathrm{~T} 1, \overline{\mathrm{T} 2}, \overline{\mathrm{T}} 3$ $\overline{\mathrm{R} 1}, \mathrm{R} 2, \mathrm{~T} 1, \overline{\mathrm{T} 2}, \mathrm{~T} 3$ $\overline{\mathrm{R} 1}, \mathrm{R} 2, \mathrm{~T} 1, \mathrm{~T} 2, \overline{\mathrm{T}} 3$ $\overline{\mathrm{R}} 1, \mathrm{R} 2, \mathrm{~T} 1, \mathrm{~T} 2, \mathrm{~T} 3$ $\mathrm{R} 1, \overline{\mathrm{R} 2}, \overline{\mathrm{T} 1}, \overline{\mathrm{T} 2}, \overline{\mathrm{T} 3}$ $\mathrm{R} 1, \overline{\mathrm{R} 2}, \overline{\mathrm{T} 1}, \overline{\mathrm{T} 2}, \mathrm{~T} 3$ $\mathrm{R} 1, \overline{\mathrm{R} 2}, \overline{\mathrm{T} 1}, \mathrm{~T} 2, \overline{\mathrm{T} 3}$ $\mathrm{R} 1, \overline{\mathrm{R} 2}, \overline{\mathrm{T} 1}, \mathrm{~T} 2, \mathrm{~T} 3$ $R 1, \overline{R 2}, T 1, \bar{T} 2, \overline{T 3}$ $\mathrm{R} 1, \overline{\mathrm{R} 2}, \mathrm{~T} 1, \overline{\mathrm{T} 2}, \mathrm{~T} 3$ $\mathrm{R} 1, \overline{\mathrm{R} 2}, \mathrm{~T} 1, \mathrm{~T} 2, \overline{\mathrm{T} 3}$ $\mathrm{R} 1, \overline{\mathrm{R} 2}, \mathrm{~T} 1, \mathrm{~T} 2, \mathrm{~T} 3$ $\mathrm{R} 1, \mathrm{R} 2, \overline{\mathrm{T} 1}, \overline{\mathrm{T} 2}, \overline{\mathrm{T} 3}$ $\mathrm{R} 1, \mathrm{R} 2, \overline{\mathrm{T} 1}, \overline{\mathrm{T} 2}, \mathrm{~T} 3$ $\mathrm{R} 1, \mathrm{R} 2, \overline{\mathrm{T} 1}, \mathrm{~T} 2, \overline{\mathrm{T} 3}$ $R 1, R 2, \overline{T 1}, T 2, T 3$ $R 1, R 2, T 1, \overline{\mathrm{T} 2}, \overline{\mathrm{T} 3}$ $R 1, R 2, T 1, \bar{T} 2, T 3$ $R 1, R 2, T 1, T 2, \bar{T} 3$ $\mathrm{R} 1, \mathrm{R} 2, \mathrm{~T} 1, \mathrm{~T} 2, \mathrm{~T} 3$

TRI-6331-94-0

Figure 4-2. Complete Notation for Scenarios in Logic Diagram for Hypothetical Events and Processes (after Cranwell et al., 1990). A bar over an event or process in a scenario indicates that the event or process does not occur within that scenario. 


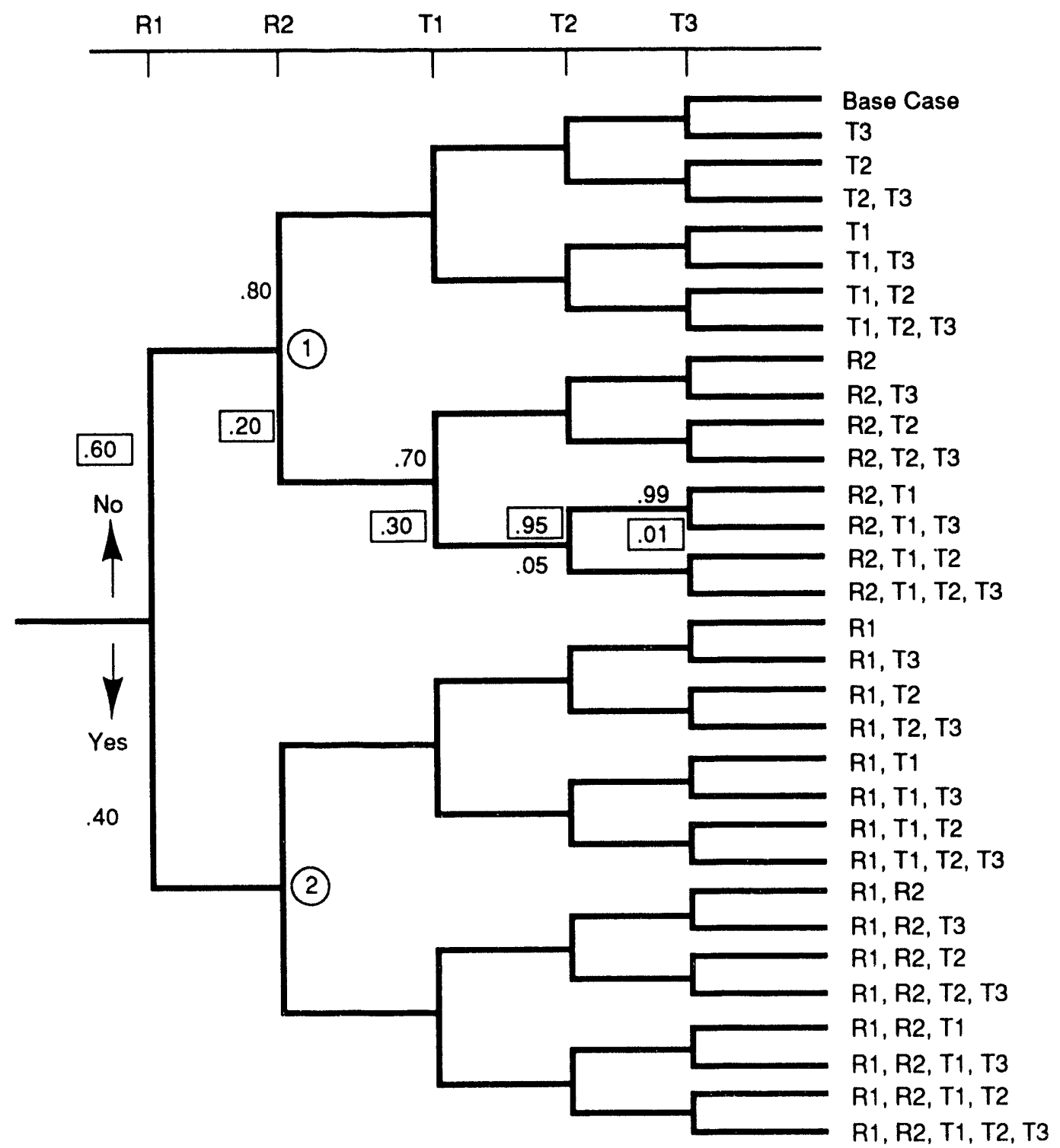

Indicates probability values needed to determine probability of scenario $R 2, T 1, T 3$

Probability of $\mathrm{R} 2, \mathrm{~T} 1, \mathrm{~T} 3=(.60)(.20)(.30)(.95)(.01)=3.4 \times 10^{-4}$

(1). (2) Branch numbers referred to in the text

TRI-6342-12.3

Figure 4-3. Example of the Calculation of the Probability of Occurrence of a Scenario Developed in a Logic Diagram (after Guzowski, 1990) 
The use of a logic diagram to construct scenarios accomplishes the two goals required of scenario identification for the construction of a CCDF. With each scenario composed of a unique combination of events and processes, the scenarios are mutually exclusive. With the sum of the scenario probabilities equal to 1, because of the conservative assumption that the scenarios define all possible futures, the scenarios constructed are comprehensive.

\subsubsection{Base-Case Scenario}

One of the products of the logic diagram is a base-case scenario. This scenario is defined by the pathway through the logic diagram resulting from "no" decisions at each of the branch points. In other words, this scenario consists of the geohydrologic conditions within the disposal system, including the waste-filled and sealed engineered facility, at the time of decommissioning, and those changes expected to occur to this system during the 10,000 years after decommissioning. From a conceptual-model point of view, the basecase scenario consists of the parameter values that define the physical characteristics of the disposal system and those processes that will occur during the "normal" evolution of the disposal system. Any other scenario developed within the logic diagram consists of a modification to this expected evolution. From a modeling view point, this modification can range from changes in parameter values within the conceptual model to the creation of alternate pathways and mechanisms for radionuclide migration.

This definition of the base-case scenario is basically the same as that used by the U.S. DOE (1986b) for the nominal case. By definition,

The nominal case is based on the expected geohydrologic, geochemical, and rock conditions. The natural variability in these characteristics and the range of uncertainty that presently exists are taken into account. In addition, these conditions include natural changes that are expected at the sites...The influence of the excavation and the effect of the heat generated by the emplaced waste on the thermal, fluid, and chemical conditions are also considered. (U.S. DOE, 1986b, p. C-2).

Depending on the specific site, the base-case scenario may define the undisturbed performance required for addressing both the Individual Protection Requirements (40 CFR 191.15) and the Ground-Water Protection Requirements (40) CFR 191.16). The Standard defines "undisturbed performance" as

the predicted behavior of a disposal system, including consideration of the uncertainties in predicted behavior, if the disposal system is not disturbed by human intrusion or the occurrence of unlikely natural events. (40 CFR 191.12(p)).

Neither the expression "unlikely natural events" nor by implication the expression "likely natural events" are defined in the Standard. If the events and processes used in the logic diagram to develop scenarios are "unlikely natural events" (and processes), which 
is a reasonable interpretation, or are limited to human-intrusion events, the base-case scenario can be used to determine undisturbed performance.

\subsubsection{Results of Scenario Construction for GCD Location}

Figure 4-4 is the logic diagram used to construct scenarios for the events identified in Step 3 of this procedure. With 4 events in this logic diagram, the number of scenarios is $2^{\mathrm{n}}$ with $\mathrm{n}$ equal to 4 , for a total of 16 scenarios.

\subsubsection{Step 5: Screening of Scenarios}

The purpose of this step is to reduce the number of scenarios for which full-scale analyses must be done. Any reduction must be consistent with the intent of the Standard with regard to performance assessments.

\subsubsection{Screening Criteria of the Basic Procedure}

Screening the scenarios is the final step of the scenario-development procedure. From a strict mathematical approach, none of the scenarios developed in the previous step can be eliminated from inclusion in the final CCDF for a particular performance assessment, because the scenario probabilities in the CCDF should sum to 1 to correspond to the scenario probabilities in the logic diagram. Because of the performance criteria established in the Standard, the guidance provided by the U.S. EPA on which events and processes can be excluded from inclusion in the CCDF can be inferred to also apply to scenarios. As stated in Appendix B of the Standard, "Some of these events and processes [and their combination to form scenarios] may be omitted from the performance assessments if there is reasonable expectation that the remaining probability distribution of cumulative releases would not be significantly changed by such omissions" (U.S. EPA, 1985, p. 38088). To identify these scenarios, Cranwell et al. (1990) developed three screening criteria. The criteria are similar to the criteria used for screening events and processes, namely, consequence, probability of occurrence, and physical reasonableness.

At this stage of the procedure, the meaning of consequence is expanded beyond the meaning in screening events and processes to include the possible release of radionuclides to the accessible environment within the time frame of regulatory concern. Simplified calculations and computer modeling of radionuclide transport can be used to determine travel times from the disposal facility to the accessible environment. In general, full-scale consequence modeling should be performed on those scenarios for which radionuclides reach the accessible environment within 10,000 years or ground-water travel times are less than 10,000 years. In some cases, logical deduction can be used to estimate the consequences of combinations of the events and processes in a scenario. For example, a scenario consisting of base-case conditions with 


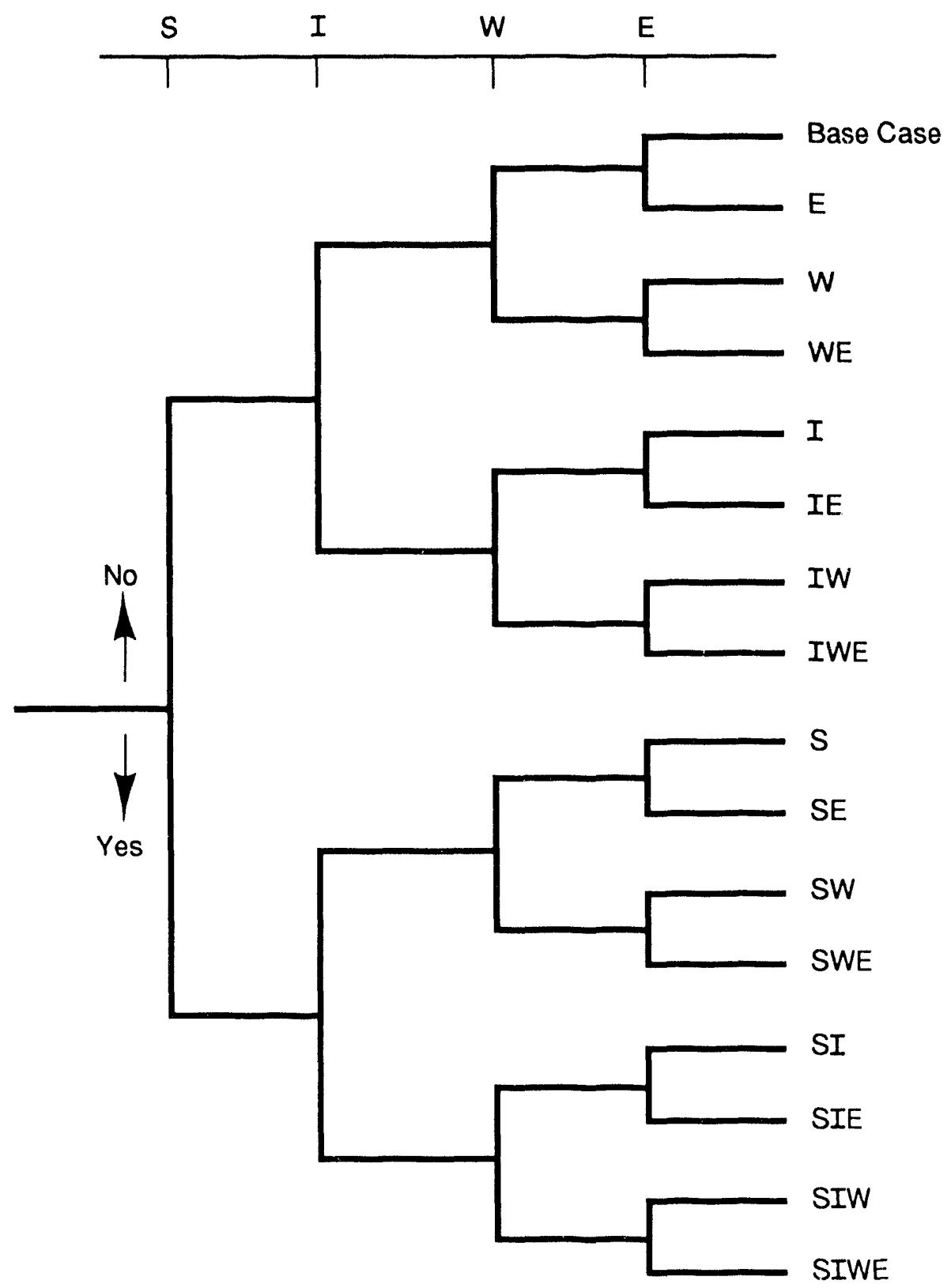

S - Subsidence occurs at RWMS

I - Irrigation occurs at RWMS

W - Drilling of withdrawal/injection well penetrates TRU borehole

E - Exploratory drilling penetrates TRU borehole

TRI-6331.95-0

Figure 4-4. Preliminary Scenarios Developed with a Logic Diagram for GCD Location 
the addition of a shallow-water withdrawal well may be assumed to result in no consequences if the base-case conditions do not result in radionuclides reaching the hydrologic unit being pumped by the withdrawal well.

Scenarios with probabilities of occurrence less than some value will have a minimal effect on the position of the CCDF. Cranwell et al. (1990) recommended following the guidance in the Standard for events and processes and using a value of less than one chance in 10,000 in 10,000 years as the basis for eliminating scenarios from consequence analyses. As was explained in the description of logic diagrams, scenarios consist of events and processes that occur and those events and processes that do not occur. In determining the probability of occurrence of a scenario, the probability of events and processes that do not occur in that scenario must be included in the calculation (see Figure 4-3).

The criterion of physical reasonableness originally was intended to identify those combinations of events and processes in the scenarios that were not physically possible. Incompatibility was possible because specific parameter values were used to define the events and processes that were to be combined to form scenarios. For example, in the original report (Cranwell et al., 1990), one fault zone with a low hydraulic conductivity acting as a barrier to ground-water flow was considered to be one feature, and a fault zone at the same location and acting as a high-conductivity zone was considered to be a separate feature. The combination of these two features with different physical properties at the same location resulted in a situation that was not physically possible. Since the development of the original version of the scenario-selection procedure prior to 1982 , specific parameter values are no longer used in the identification of the events and processes but are instead handled through computer-modeling techniques. Conditionality (when necessary) of specific values between different parameters can be addressed in the parameter-sampling scheme ior each parameter during modeling. Because of changes in how events and processes are identified, all of the combinations of events and processes within each scenario will be physically reasonable.

How to address the different sequences of occurrence of the events and processes within a scenario during analyses is a commonly expressed concern with the Cranwell et al. (1990) approach to scenario development. As the scenario-development procedure was developed, the events and processes within a scenario were assumed to occur at the beginning of the period of regulatory concern and to continue for the entire time interval. The results of such an analysis are a conservative estimation of performance of the disposal system, because the disruptive aspects of each event and process would occur for the maximum duration of time. This approach to performance assessments has been used for analysis of the GCD disposal system.

As computing capabilities have increased since the development of the Cranwell et al. (1987) performance-assessment methodology, the analyses for some performance 
assessments have become more complicated and sophisticated (e.g., WIPP Performance Assessment Division, 1991; Rechard, 1992). For example, the time of occurrence of an event or process can be treated as a parameter value that is sampled during modeling. If two events or processes cannot occur within a certain time interval of each other, the sampled time of occurrence of one event or process can be conditional on the sampled time of occurrence of the other event or process. The impact of this approach to scenario analyses on the estimation of performance of a disposal system relative to the performance measure provided by the Standard has not been determined at this time.

Screening of the scenarios developed through the use of a logic diagram can result in the identification of those scenarios for which full-scale consequence analyses for comparison to the performance measures stated in the Standard are not necessary. By identifying those scenarios that will have minimal effect on the shape or location of the $\mathrm{CCDF}$, the resources spent on consequence analyses can be reduced.

\subsubsection{Screening of GCD Scenarios}

No screening of the GCD scenarios has been attempted. All of the combinations of events in each scenario are physically reasonable. Time and resources were not available within the time frame of this draft report with which to use consequence analyses or probability estimation to screen scenarios.

\subsubsection{Plans for Completion of Scenario Identification}

Current plans for the GCD Project include completion of the final scenario report in early March of 1995. Revisions have been made to the scenario development in response to technical reviews from personnel within the performance-assessment program and those associated with other waste-disposal programs for Area 5 of the NTS. Additional technical reviews by personnel outside of the Area 5 programs will be sought. In addition to technical reviews, additional technical data and information to be obtained through site-characterization activities will be incorporated into scenario development through a second interation of the scenario-development procedure, starting with Step 3--FEP Screening. Any newly obtained data and information will be examined to determine whether any of the event-and-process screening decisions, either for inclusion or for exclusion from scenario development, should be changed. If necessary, scenarios will be reconstructed with the events and processes remaining after screening of the events and processes.

Scenario screening will be the next step. Scenario probabilities will be incorporated into the report and used as a screening criterion. If deemed necessary, consequence modeling also will be used to identify which scenarios are appropriate for performanceassessment analyses. A last series of technical reviews will complete the process of identifying a final set of scenarios for use in performance assessments. 


\subsection{SUMMARY AND CONCLUSIONS}

A scenario-development procedure specifically developed by SNL (Cranwell et al., 1990) for the U.S. NRC to address the Containment Requirements of the Standard has been used to identify potentially disruptive scenarios for use in performance assessments of the GCD disposal system. This procedure consists of five steps that start with identifying an initial list of events and processes, classifiying the events and processes, screening the events and processes using specific criteria, developing a comprehensive set of scenarios from the events and processes remaining after screening, and screening the scenarios to identify those requiring complete performance-assessment analyses.

In applying this procedure to the GCD location, a master list of 761 features, events, processes, and miscellaneous other listings was derived by combining the lists or descriptions in 11 references dealing with scenario development and/or performance assessments. The master list was reduced to an initial list of 205 primarily by the elimination of duplications and redundancies. Screening of the initial list identified 4 events that cannot be screened out from consideration in scenario development at this time. As redefined for scenario development, these events are (1) exploratory drilling penetrates a TRU borehole, (2) drilling of withdrawal or injection well penetrates a TRU borehole, (3) subsidence or caving occurs within the RWMS, and (4) irrigation occurs at the RWMS.

For scenario development, a logic diagram was used to develop all possible combinations of the 4 remaining events. These 4 events produced 16 scenarios. No screening of the scenarios to identify which scenarios require complete performance-assessment analyses was attempted.

The number of scenarios is likely to be reduced as additional site-specific information becomes available through site characterization and as currently existing data and information is made available in citable documents. Of the 4 remaining events, subsidence at the GCD boreholes may be screened out on the basis of low consequence, if analyses indicate that the lifetime of the depressions caused by subsidence is short because of the high activity of surficial processes at the GCD location or if corrective actions taken during the time period of active institutional controls is likely to preclude subsidence during later times. Additional reduction could be accomplished by combining the drilling of exploratory boreholes with the drilling of water/injection boreholes. Although these two drilling events seem to be nearly identical in the degree of disruption of the disposal facility, the decomposition of the events for estimating probabilities of occurrence may result in substantially different estimated probabilities.

If the number of events for scenario development is reduced to a number that can easily be handled by consequence modeling, the GCD project may want to experiment with scenario development. One possibility is to consider extreme erosion resulting from 
short-term climatic events as a separate event from erosion in the base-case scenario. For example, the upper 5 percent (or 2 percent, or even 1 percent) of the entire range of estimated possible erosion depths or the extreme depths of channels observed in the field may be considered as an event separate from erosion resulting from long-term climatic variability. Such an approach to scenario development may be feasible, because events of base-case erosion and extreme-event erosion could occur and be physically reasonable in the same scenario. One problem with this modification of the scenario-development procedure would be defining and justifying the extreme-erosion event.

Based on certain implementation assumptions, the use of the Cranwell et al. (1990) procedure for scenario development has produced a comprehensive set of mutually exclusive scenarios that are reproducible and auditable for use in performance assessments to evaluate the GCD location with respect to the Containment Requirements of the Standard. Comprehensive refers to the fact that all possible scenarios are developed for those FEPs that survive the FEP-screening step of the procedure. Mutually exclusive means that each scenario consists of a unique combination of events. The scenarios are reproducible in that an identical set of events and processes that remain after screening will always produce the same set of scenarios. This procedure is auditable in that the steps of the procedure are well defined, and the decisions made in implementing the procedure are documented.

The scenarios developed in this report are preliminary and are subject to change in response to review comments and the availability of new data and information resulting from site-characterization activities. A second iteration of the scenario-development procedure is planned to incorporate modifications in response to additional review comments, additional data and information unavailable for the first iteration, and scenario probabilities for use in scenario screening. Completion of the second iteration is scheduled for March 1995. 


\subsection{REFERENCES}

Andersson, J., T. Carlsson, T. Eng, F. Kautsky, E. Söderman, and S. Wingefors, 1989. The Joint SKI/SKB Scenario Development Project, SKB-TR89-35, Svensk Kärnbränslehantering $\mathrm{Ab}$, Stockholm, Sweden.

Barnes, H., E.B. Ekren, C.L. Rodgers, and D.C. Hedlund, 1982. Geologic and Tectonic Maps of the Mercury Quadrangle, Nye and Clark Counties, Nevada, Miscellaneous Investigations Map I-1197, U.S. Geological Survey, Washington, D.C.

Bates, R.L., and J.A. Jackson, 1987. Glossary of Geology (3rd ed.), American Geological Institute, Alexandria, VA.

Birkeland, P.W., 1984. Soils and Geomorphology, Oxford University Press, New York, NY.

Bull, W.B., 1991. Geomorphic Response to Climatic Change, Oxford University Press, New York, NY.

Burkholder, H.C., 1980. "Waste Isolation Performance Assessment--A Status Report," in Scientific Basis for Nuclear Waste Management, Ed. C.J.M. Northrup, Jr., Plenum Press, New York, NY, Vol. 2, p. 689-702.

Campbell, J.E., R.T. Dillon, M.S. Tierney, H.T. Davis, P.E. McGrath, F.J. Pearson, Jr., H.R. Shaw, J.C. Helton, and F.A. Donath, 1978. Risk Methodology for Geologic Disposal of Radioactive Waste: Interim Report, SAND78-0029 (NUREG/CR0458), Sandia National Laboratories, Albuquerque, NM.

Carr, W.J., 1984. Regional Structural Setting of Yucca Mountain, Southwestern Nevada, and Late Cenozoic Rates of Tectonic Activity in Part of the Southwestern Great Basin, Nevada and California, Open-File Report 84-854, U.S. Geological Survey, Denver, CO.

Carr, W.J., G.D. Bath, D.L. Healey, and R.M. Hazelwood, 1967. Geology of Northern Frenchman Flat, Nevada Test Site, Technical Letter NTS-188, U.S. Geological Survey, Denver, CO.

Carr, W.J., G.D. Bath, D.L. Healey, and R.M. Hazelwood, 1975. Geology of Northern Frenchman Flat, Nevada Test Site, USGS-474-216, U.S. Geological Survey, Denver, CO.

Case, C., J. Davis, R. French, and S. Raker, 1984. Site Characterization in Connection with the Low Level Defense Waste Management Site in Area 5 of the Nevalda Test 
Site, Nye County, Nevada--Final Report, DOE/NV/10162-13, Water Resources Center, Desert Research Institute, Reno, NV.

Chu, M.S.Y., and E.A. Bernard, 1991. Waste Inventory and Preliminary Source Term Model for the Greater Confinement Disposal Site at the Nevada Test Site, SAND91-0170, Sandia National Laboratories, Albuquerque, NM.

Claiborne, H.C., and F. Gera, 1974. Potential Containment Failure Mechanisms and Their Consequences at a Radioactive Waste Repository in Bedded Salt in New Mexico, ORNL-TM-4639, Oak Ridge National Laboratory, Oak Ridge, TN.

Conrad, S.H., 1993. "Using Environmental Tracers to Estimate Recharge Through an Arid Basin," in Proceedings of the Fourth Annual International Conference on High Level Radioactive Waste Management, April 26-30, 1993, Las Vegas, NV, American Nuclear Society, Inc., La Grange Park, IL, Vol. 1, p. 132-137.

Cranwell, R.M., J.E. Campbell, J.C. Helton, R.L. Iman, D.E. Longsine, N.R. Ortiz, G.E. Runkle, and M.J. Shortencarier, 1987. Risk Methodology for Geologic Disposal of Radioactive Waste: Final Report, SAND81-2573 (NUREG/CR-2452), Sandia National Laboratories, Albuquerque, NM. (Original version of this report published in 1982 under the same title and report numbers).

Cranwell, R.M., R.V. Guzowski, J.E. Campbell, and N.R. Ortiz, 1990. Risk Methodology for Geologic Disposal of Radioactive Waste: Scenario Selection Procedure, NUREG/CR-1667 (SAND80-1429), Sandia National Laboratories, Albuquerque, NM. (Original version of this report published in 1982 under same title and report numbers).

Davis, P.A., L.L. Price, K.K. Wahi, M.T. Goodrich, D.P. Gallegos, E.J. Bonano, and R.V. Guzowski, 1990. Components of an Overall Performance Assessment Methodology, NUREG/CR-5256 (SAND88-3020), Sandia National Laboratories, Albuquerque, NM.

Dockery, H.A., 1984. Rotation of Late Cenozoic Extensional Stresses, Yucca Flat Region, Nevada Test Site, Nevada, unpublished Ph.D. dissertation, Rice University, Houston, TX.

Gibbons, A.B., E.N. Hinrichs, W.R. Hansen, and R.W. Lemke, 1963. Geology of the Rainier Mesa Quadrangle, Nye County, Nevada, Geologic Quadrangle Map GQ-215, U.S. Geological Survey, Washington, D.C.

Gustafson, D.L., S.E. Rawlinson, and J.J. Miller, 1993a. Summary of Natural Resources That Potentially Influence Human Intrusion at the Area 5 Radioactive Waste 
Management Site DOE/Nevada Test Site, Nye County, Nevada, Raytheon Services Nevada, Las Vegas, NV.

Gustafson, D.L., S.M. Parsons, and K.E. Snyder, 1993b. Greater Confinement Disposal Borehole Logging at the Area 5 Radioactive Waste Management Site DOE Nevada Test Site, Nye County, Nevada, Raytheon Services Nevada, Las Vegas, NV.

Guzowski, R.V., 1990. Preliminary Identification of Scenarios That May Affect the Escape and Transport of Radionuclides From the Waste Isolation Pilot Plant. Southeastern New Mexico, SAND89-7149, Sandia National Laboratories, Albuquerque, NM.

Guzowski, R.V., 1991. Evaluation of Applicability of Probability Techniques to Determining the Probability of Occurrence of Potentially Disruptive Intrusive Events at the Waste Isolation Pilo: Plant, SAND90-7100, Sandia National Laboratories, Albuquerque, NM.

Guzowski, R.V., and J.C. Helton, 1991. "Chapter 4. Scenarios for Compliance Assessment," in Preliminary Comparison with 40 CFR Part 191, Subpart B for the Waste Isolation Pilot Plant. December 1991. Volume 1: Methodology and Results, SAND91-0893/1, Sandia National Laboratories, Albuquerque, NM.

Hartmann, W.K., 1979. Long-Term Meteorite Hazards to Buried Nuclear Waste, PNL2851, Pacific Northwest Laboratory, Richland, WA, p. VI-1 through VI-15.

Hertzler, C.L., 1989. Status of Development and Screening of Release Scenarios for Greater Confinement Disposal of Transuranic Waste at the Nevada Test Site September 1989, EGG-SARE-8768, EG\&G Idaho, Inc., Idaho Falls, ID.

Hertzler, C.L., and C.L. Atwood, 1989. Preliminary Development and Screening of Release Scenarios for Greater Confinement Disposal of Transuranic Waste at the Nevada Test Site, EGG-SARE-8767, EG\&G Idaho, Inc., Idaho Falls, ID.

Hudson, M.R., 1992. "Paleomagnetic Data Bearing on the Origin of Arcuate Structures in the French Peak--Massachusetts Mountain Area of Southern Nevada," Geological Society of America Bulletin, Vol. 1(14, no. 5, p. 581-594.

Hunter, R.L., 1983. Preliminary Scenarios for the Release of Radioactive W'aste From a Hypothetical Repository in Basalt of the Columbia Plateau, SAND83-1342 (NUREG/CR-3353), Sandia National Laboratories, Albuquerque, NM. 
Hunter, R.L., 1989. Events and Processes for Constructing Scenarios for the Release of Transuranic Waste From the Waste Isolation Pilot Plant, Southeastern New Mexico, SAND89-2546, Sandia National Laboratories, Albuquerque, NM.

International Atomic Energy Agency, 1983. Concepts and Examples of Safety Analyses for Radioactive Waste Repositories in Continental Geological Formations, Safety Series No. 58, International Atomic Energy Agency, Vienna, Austria.

Kärnbränslesakerhet, 1978. Handling of Spent Nuclear Fuel and Final Storage of Vitrified High Level Reprocessing Waste, Kärnbränslesakerhet, Stockholm, Sweden.

Koplik, C.M., M.F. Kaplan, and B. Ross, 1982. "The Safety of Repositories for Highly Radioactive Wastes," Reviews of Modern Physics, Vol. 54, no. 1, p. 269-310.

Logan, S.E., and M.C. Berbano, 1978. Development and Application of a Risk Assessment Method for Radioactive Waste Management, Volume II: Implementation for Terminal Storage in Reference Repository and Other Applications, EPA 520/6-78-005, U.S. Environmental Protection Agency, Washington, D.C.

Maldonado, F., 1977. Summary of the Geology and Physical Properties of the Climax Stock, Nevada Test Site, Open-File Report 77-0356, U.S. Geological Survey, Washington, D.C.

Marvin, R.F., F.M. Byers, Jr., H.H. Mehnert, P.P. Orkild, and T.W. Stern, 1970. "Radiometric Ages and Stratigraphic Sequence of Volcanic and Plutonic Rocks, Southern Nye and Western Lincoln Counties, Nevada," Geological Society of America Bulletin, Vol. 81, no. 9, p. 2657-2676.

McCord, J.T., 1990. Review of Data and Information on Saturated Zone Groundwater Flow at the Nevada Test Site. With Special Reference to Area 5, Letter Report to U.S. Department of Energy Nevada Operations Office, Sandia National Laboratories, Albuquerque, NM.

Merrett, G.J., and P.A. Gillespie, 1983. Nuclear Fuel Waste Disposal: Long-Term Stability Analysis, AECL-6820, Atomic Energy of Canada Limited, Pinawa, Manitoba.

Naeser, C.W., and F. Maldonado, 1981. Fission-Track Dating of the Climax and Gold Meadows Stocks, Nye County, Nevada, Professional Paper 1199-E, U.S. Geological Survey, Washington, D.C., p. 45-47. 
Nuclear Energy Agency, 1992. Systematic Approach to Scenario Development. A Report of the NEA Working Group on the Identification and Selection of Scenarios for Performance Assessment of Radioactive Waste Disposal, Nuclear Energy Agency, Paris, France.

NWPA (Nuclear Waste Policy Act), 1982. The Nuclear Waste Policy Act of 1982, Public Law 97-425; 96 Statute 2201.

NWPAA (Nuclear Waste Policy Act Amendments), 1987. The Nuclear Waste Amendments Policy Act of 1987, Public Law 100-203, 101 Statute 1330.

Poole, F.G., D.P. Elston, and W.J. Carr, 1965. Geologic Map of the Cane Spring Quadrangle, Nye County, Nevada, Quadrangle Map GQ-455, U.S. Geological Survey, Washington, D.C.

Price, L.L., S.H. Conrad, D.A. Zimmerman, N.E. Olague, K.C. Gaither, W.B. Cox, J.T. McCord, and C.P. Harlan, 1993a. Preliminary Performance Assessment of the Greater Confinement Disposal Facility at the Nevada Test Site. Volume 1: Executive Summary, SAND91-0047, Sandia National Laboratories, Albuquerque, NM.

Price, L.L., S.H. Conrad, D.A. Zimmerman, N.E. Olague, K.C. Gaither, W.B. Cox, J.T. McCord, and C.P. Harlan, 1993b. Preliminary Performance Assessment of the Greater Confinement Disposal Facility at the Nevada Test Site. Volume 2: Technical Discussion, SAND91-0047, Sandia National Laboratories, Albuquerque, NM.

Price, L.L., D.A. Zimmerman, N.E. Olague, S.H. Conrad, and C.P. Harlan, 1993c. Preliminary Performance Assessment of the Greater Confinement Disposal Facility at the Nevada Test Site. Volume 3: Supporting Details, SAND91-0047, Sandia National Laboratories, Albuquerque, NM.

Prij, J., B. Blok, D. Fraters, P. Glasbergen, G.M.H. Laheij, W. Slagter, A.F.M. Slot, P. Uijt de Haag, H. van de Weerd, A.F.B. Wildenborg, and D. Zanstra, 1991. PROSA: PRobabilistisch Onderzoek aan de veiligheid van in Steenzout opgeborgen radioactief Afval, Concept Tussenrapport 4, Scenario Selectie, Energieonderzoek Centrum Nederland, Petten, the Netherland.

Rechard, R.P., ed., 1992. User's Reference Manual for CAMCON: Compliance Assessment Methodology Controller Version 3.0, SAND90-1983, Sandia National Laboratories, Albuquerque, NM. 
RSN (Raytheon Services Nevada), 1991. Surficial Geology of the Area 5 Radioactive Waste Management Site. Interim Report Review Draft, Raytheon Services Nevada, Las Vegas, NV.

Safe Drinking Water Act, 1974. 42 U.S.C. $300 f$ et seq.

Sinnock, S., 1982. Geology of the Nevada Test Site and Nearby Areas, Southern Nevada, SAND82-2207, Sandia National Laboratories, Albuquerque, NM.

Smith, C.B., D.J. Egan, Jr., W.A. Williams, J.M. Grunlke, C.-Y. Hung, and B.L. Serini, 1982. Population Risks from Disposal of High-Level Radioactive Wastes in Geologic Repositories, EPA 520/3-80-006, U.S. Environmental Protection Agency, Washington, D.C.

Snyder, K.E., S.M. Parsons, and D.L. Gustafson, 1993. Field Results of Subsurface Geologic Mapping at the Area 5 Radioactive Waste Management Site DOE/Nevada Test Site, Nye County, Nevada, Raytheon Services Nevada, Las Vegas, NV.

Stephens, M.E., and B.W. Goodwin, 1990. "Scenario Analysis for the Postclosure Assessment of the Canadian Concept for Nuclear Fuel Waste Disposal," in International Symposium on the Safety Assessment of Radioactive Waste Repositories, October 9-13, 1989, Paris, France, Organisation for Economic CoOperation and Development, p. 405-415.

Swadley, W.C., 1983. Map Showing Surficial Geology of the Lathrop Wells Quadrangle, Nye County, Nevada, Miscellaneous Investigations Map I-1361, U.S. Geological Survey, Washington, D.C.

Swadley, W.C., and H.E. Huckins, 1989. Surficial Geologic Map of the Specter Range NW Quadrangle, Nye County, Nevada, Miscellaneous Investigations Map I-1884, U.S. Geological Survey, Washington, D.C.

U.S. DOE (Department of Energy), 1986a. Environmental Assessment for the LGF Spill Test Facility at Frenchman Flat, Nevada Test Site, DOE/EA-3009, U.S. Department of Energy, Las Vegas, NV.

U.S. DOE (Department of Energy), 1986b. A Multiattribute Utility Analysis of Sites Nominated For Characterization For The First Radioactive-Waste Repository--A Decision-Aiding Methodology, DOE/RW-(0)74, U.S. Department of Energy, Washington, D.C. 
U.S. DOE (Department of Energy), 1988. Site Characterization Plan, Yucca Mountain Site, Nevada Research and Development Area, DOE/RW-0199, U.S. Department of Energy, Washington, D.C.

U.S. EPA (Environmental Protection Agency), 1985. Environmental Standards for the Management and Disposal of Spent Nuclear Fuel, High-Level and Transuranic Radioactive Wastes; Final Rule, 40 CFR Part 191, Federal Register, Vol. 50, no. 182, p. 38066-38089.

U.S. EPA (Environmental Protection Agency), 1993. CFR Part 191. Environmental Radiation Protection Standards for the Management and Disposal of Spent Nuclear Fuel, High-Level and Transuranic Wastes; Final Rule, unpublished final draft dated July 26, 1993.

Waste Isolation Pilot Plant Land Withdrawal Act. 1992. Public Law 102-579.

Winograd, I.J., and W. Thordarson, 1975. Hydrogeologic and Hydrochemical Framework, South-Central Great Basin, Nevada-California, with Special Reference to the Nevada Test Site, Open-File Report 80-569, U.S. Geological Survey, Washington, D.C.

WIPP Performance Assessment Division, 1991. Preliminary Comparison with 40 CFR Part 191, Subpart B for the Waste Isolation Pilot Plant, December 1991. Volume 2: Probability and Consequence Modeling, SAND91-0893/2, Sandia National Laboratories, Albuquerque, NM.

Yount, J.C., R.R. Shroba, C.R. McMasters, H.E. Huckins, and E.A. Rodriguez, 1987. Trench Logs from a Strand of the Rock Valley Fault System, Nevada Test Site, Nye County, Nevada, Miscellaneous Field Studies Map MF-1824, U.S. Geological Survey, Washington, D.C. 
APPENDIX A

GEOLOGIC TIME SCALE

A -1 
Geologic Time Scale

\begin{tabular}{|c|c|c|c|}
\hline ERA & PERIOD & EPOCH & $\begin{array}{c}\text { AGE IN } \\
\text { MILLIONS } \\
\text { OF YEARS } \\
\end{array}$ \\
\hline \multirow{7}{*}{ Cenozoic } & \multirow{3}{*}{ Quaternary } & Holocene & -001 \\
\hline & & Pleistocene & \\
\hline & & Pliocene & 53 \\
\hline & \multirow{4}{*}{ Tertiary } & Miocene & \\
\hline & & Oligocene & \\
\hline & & Eocene & \\
\hline & & Paleocene & \\
\hline \multirow[t]{3}{*}{ Mesozoic } & Cretaceous & & -144 \\
\hline & Jurassic & & $-208-$ \\
\hline & Triassic & & $-245-$ \\
\hline \multirow{7}{*}{ Paleozoic } & Permian & & $-286-$ \\
\hline & Pennsylvanian & & $-320-$ \\
\hline & Mississippian & & $-360-$ \\
\hline & Devonian & & -408 \\
\hline & Silurian & & -438 \\
\hline & Ordovician & & $505-$ \\
\hline & Cambrian & & \\
\hline Precambrian & & & \\
\hline
\end{tabular}

TRI.6331.99-0

(after Palmer, A.R., compiler, 1983. The Decade of North American Geology. 1983 Geologic Time Scale. Geological Society of America, Boulder, CO.) 


\section{APPENDIX B \\ REFERENCES USED FOR GCD SCENARIO SELECTION OF FEATURES, EVENTS, AND PROCESSES (FEPS)}


B-2 


\section{REFERENCES USED TO DEVELOP MASTER FEP LIST}

1. Andersson, J., T. Carlsson, T. Eng, F. Kautsky, E. Söderman, and S. Wingefors, 1989. The Joint SKI/SKB Scenario Development Project, SKB-TR89-35, Svensk Kärnbränslehantering Ab, Stockholm, Sweden.

2. Burkholder, H.C., 1980. "Waste Isolation Performance Assessment--A Status Report," in Scientific Basis for Nuclear Waste Management, Ed. C.J.M. Northrup, Jr., Plenum Press, New York, NY, Vol. 2, p. 689-702.

3. Guzowski, R.V., 1990. Preliminary Identification of Scenarios That May Affect the Escape and Transport of Radionuclides From the Waste Isolation Pilot Plant. Southeastern New Mexico, SAND89-7149, Sandia National Laboratories, Albuquerque, NM.

4. Hertzler, C.L., and C.L. Atwood, 1989. Preliminary Development and Screening of Release Scenarios for Greater Confinement Disposal of Transuranic Waste at the Nevada Test Site, EGG-SARE-8767, EG\&G Idaho, Inc., Idaho Falls, ID.

5. Hunter, R.L., 1983. Preliminary Scenarios for the Release of Radioactive Waste From a Hypothetical Repository in Basalt of the Columbia Plateau, SAND83-1342 (NUREG/CR-3353), Sandia National Laboratories, Albuquerque, NM.

6. Hunter, R.L., 1989. Events and Processes for Constructing Scenarios for the Release of Transuranic Waste From the Waste Isolation Pilot Plant, Southeastern New Mexico, SAND89-2546, Sandia National Laboraotories, Albuquerque, NM.

7. International Atomic Energy Agency, 1983. Concepts and Examples of Safety Analyses for Radioactive Waste Repositories in Continental Geological Formations, Safety Series No. 58, International Atomic Energy Agency, Vienna, Austria.

8. Koplik, C.M., M.F. Kaplan, and B. Ross, 1982. "The Safety of Repositories for Highly Radioactive Wastes," Reviews of Modern Physics, Vol. 54, no. 1, p. 269-310.

9. Merrett, G.J., and P.A. Gillespie, 1983. Nuclear Fuel Waste Disposal: LongTerm Stability Analysis, AECL-6820, Atomic Energy of Canada Limited, Pinawa, Manitoba.

10. Nuclear Energy Agency, 1992. Systematic Approach to Scenario Development, A Report of the NEA Working Group on the Identification and Selection of 
Scenarios for Performance Assessment of Radioactive Waste Disposal, Nuclear Energy Agency, Paris, France.

11. Prij, J., B. Blok, D. Fraters, P. Glasbergen, G.M.H. Laheij, W. Slagter, A.F.M. Slot, P. Uijt de Haag, H. van de Weerd, A.F.B. Wiljenborg, and D. Zanstra, 1991. PROSA: PRobabilistisch Onderzoek, aan de veiligheid van in Steenzout opgeborgen radioactief Afval, Concept Tussenrapport 4, Scenario Selectie, Energieonderzoek Centrum Nederland, Petten, the Netherland. 
1. Andersson, J., T. Carlsson, T. Eng, F. Kautsky, E. Söderman, and S. Wingefors, 1989. The Joint SKI/SKB Scenario Development Project, SKB-TR89-35, Svensk Kärnbränslehantering Ab, Stockholm, Sweden.

criticality

radioactive decay; heat

recoil of alpha-decay

gas generation: He production

radiolysis

$\mathrm{H}_{2} / \mathrm{O}_{2}$ explosions

$\mathrm{Pb}-\mathrm{I}$ reactions

Gas generation

I, Cs-migration to fuel surface

solubility within fuel matrix

recrystallization

redox potential

dissolution chemistry

damaged or deviating fuel

sudden energy release

release of radionuclides from failed canister

chemical reactions (copper corrosion)

coupled effects (electrophoresis)

internal corrosion due to waste

role of the eventual channeling within the canister

role of chlorides in copper corrosion

repository induced $\mathrm{Pb} / \mathrm{Cu}$ electrochemical reactions

natural telluric electrochemical reactions

pitting

corrosive agents, sulphides, oxygen etc

creeping of copper

backfill effects on copper corrosion

microbes

creeping of copper

thermal cracking

electro-chemical cracking

stress corrosion cracking

loss of ductility

radiation effects on canister

cracking along welds

external stress

hydrostatic pressure on canister

internal pressure

voids in the lead filling

random canister defects - quality control

common cause canister defects - quality control

degradation of the bentonite by chemical reactions

saturation of sorption sites

effects of bentonite on ground-water chemistry

colloid generation - source

coagulation of bentonite

sedimentation of bentonite

reactions with cement pore water 
near field buffer chemistry

radiolysis

interactions with corrosion products and waste

redox front

perturbed buffer material chemistry

radiation effects on bentonite

swelling of bentonite into tunnels and cracks

uneven swelling of bentonite

movement of canister in buffer/backfill

mechanical failure of buffer/backfill

erosion of buffer/backfill

thermal effects on the buffer material

diffusion - surface diffusion

swelling of corrosion products

preferential pathways in the buffer/backfill

flow through buffer/backfill

soret effect

backfill material deficiencies

gas transport in bentonite

oxidizing conditions

pH-deviations

colloids, complexing agents

sorption

matrix diffusion

reconcentration

thermochemical changes

change of ground-water chemistry in nearby rock

complexing agents

mechanical failure of repository

excavation/backfilling effects on nearby rock

hydraulic conductivity change - excavation/backfilling effect

mechanical effects - excavation/backfilling effects

extreme channel flow of oxidants and nuclides

thermal buoyancy

changes of ground-water flow

faulting

thermo-hydro-mechanical effects

enhanced rock fracturing

creeping of rock mass

chemical effects of rock reinforcement

saline or fresh ground-water intrusion

non-sealed repository

stray materials left

decontamination materials left

chemical sabotage

co-storage of other waste

poorly designed repository

poorly constructed repository

unsealed boreholes and/or shafts

accidents during operation

degradation of hole- and shaft seals

near storage of other waste 
volcanism

resaturation

earthquakes

uplift and subsidence

permafrost

enhanced ground-water flow

effect of plate movements

changes of the magnetic field

future boreholes and undetected past boreholes

accumulation of gases under permafrost

changed hydrostatic pressure on canister

stress changes of conductivity

dissolution of fracture fillings/precipitations

erosion on surface/sediments

human-induced actions on ground-water recharge

underground dwellings

meteorite

underground test of nuclear devices

change in sea level

desert and unsaturation

waste retrieval, mining

geothermal energy production

other future uses of crystalline rock

reuse of borehoiles

archeological intrusion

explosions

postclosure monitoring

unsuccessful attempt of site improvement

water producing well

glaciation

methane intrusion

solubility and precipitation

colloid generation and transport

groundwater recharge/discharge

undetected fracture zones

gas transport

far field hydrochemistry - acids, oxidants, nitrate

dispersion

dilution

weathering of flow paths

nuclear war

human-induced climate change

river meandering

no ice age

intruding dikes

undetected discontinuities

geothermally induced flow

tectonic activity - large scale

accumulation in sediments

accumulation in peat

intrusion into accumulation zone in the biosphere

chemical toxicity of wastes 
isotopic dilution

human-induced changes in surface hydrology altered surface water chemistry by humans loss of records

diagenesis

city on the site 
2. Burkholder, H.C., 1980. "Waste Isolation Performance Assessment -- A Status Report," in Scientific Basis for Nuclear Waste Management, Ed. C.J.M. Northrup, Jr., Plenum Press, New York, NY, Vol. 2, p. 689-702.

Human-Induced Phenomena

Improper Design/Operation

shaft seal failure

improper waste emplacement

Undetected Past Intrusion

undiscovered boreholes

mine shafts

Inadvertent Future Intrusion archeological exhumation weapons testing non-nuclear waste disposal

resource mining (mineral hydrocarbon, geothermal, salt)

storage of hydrocarbons or compressed air

Intentional Intrusion

war

sabotage

waste recovery

Transport Agent Introduction

irrigation

reservoirs

intentional artificial ground-water recharge or withdrawal chemical liquid waste disposal

Biosphere Alteration

establishment of new population center

climate modification

Natural Phenomena

Climatic Fluctuations

Glaciation

Denudation and Stream Erosion

Magmatic Activity

extrusive

intrusive

Epeirogenic Displacement igneous emplacement isostasy

Orogenic Diastrophism near-field faulting far-field faulting diapirism diagenesis

Static Fracturing

surficial fissuring impact fracturing hydraulic fracturing

Meteorites

Dissolutioning

Sedimentation 
Flooding

Undetected Features

faults, shear zones

breccia pipes

lava tubes

gas or brine pockets

Waste and Repository-Induced Phenomena

Thermal Effects

differential elastic response

non-elastic response

fluid pressure changes

fluid migration

Chemical Effects geochemical alterations corrosion waste package - geology interactions biochemical gas generation

Mechanical Effects

local fracturing

canister movement dewatering

Radiological Effects

material property changes

radiolysis

criticality

decay product gas generation 
3. Guzowski, R.V., 1990. Preliminary Identification of Scenarios That May Affect the Escape and Transport of Radionuclides From the Waste Isolation Pilot Plant, Southeastern New Mexico, SAND89-7149, Sandia National Laboratories, Albuquerque, NM.

Human-Induced Events and Processes

Inadvertent Future Intrusions

explosions

drilling

mining

injection wells

withdrawal wells

Hydrologic Stresses

irrigation

damming of streams or rivers

Natural Events and Processes

Celestial bodies meteorite impact

Surficial Events and Processes erosion/sedimentation

glaciation

pluvial periods

sea-level variations

hurricanes

seiches

tsunamis

regional subsidence or uplift (also applies to subsurface)

mass wasting

flooding

Subsurface events and processes

diapirism

seismic activity

volcanic activity

magmatic activity

formation of dissolution cavities

formation of interconnected fracture systems

faulting

Waste and Repository-Induced Events and Processes

subsidence and caving

shaft and borehole seal degradation

thermally induced stress/fracturing in host rock

excavation induced stress/fracturing in host rock 
4. Hertzler, C.L., and C.L. Atwood, 1989. Preliminary Development and Screening of Release Scenarios for Greater Confinement Disposal of Transuranic Waste at the Nevada Test Site, EGG-SARE-8767, EG\&G Idaho, Inc., Idaho Falls, ID.

Events and Processes Caused by Man

well-drilling inadvertent intruder

human surface activities

mining inadvertent intruder

earthquake from manmade causes

hydrology change from manmade causes

dam and reservoir, manmade

fire and explosion

climate control

geochemical changes form manmade causes

weapons testing

intentional intrusion

undetected past intrusion

unanticipated intrusion

Natural Phenomena

infiltration and evapotranspiration

climatic change

land erosion

earthquake from natural causes

faulting

igneous activity

landslide

sedimentation/aggradation

regional subsidence or uplift

local subsidence/caving

radial dispersion

lateral ground-water flow in the unsaturated zone

brush fire

glacial activity

meteorite impact

hurricane

tornado

dissolution

sea level change

hydrology change from natural causes

diagenesis

diapirism

geochemical changes from natural causes

dam and reservoir formation from natural causes

fluid interactions

undetected features or processes

Events and Processes Caused by TRU Waste

thermal changes in burial zone caused by heat generation

chemical effects

mechanical effects

criticality 
decay product gas generation

fire and explosion of waste after burial

improper waste emplacement

chemical liquid waste disposal

shaft/borehole seal failure

unanticipated waste composition 
5. Hunter, R.L., 1983. Preliminary Scenarios for the Release of Radioactive Waste From a Hypothetical Repository in Basalt of the Columbia Plateau, SAND83-1342 (NUREG/CR-3353), Sandia National Laboratories, Albuquerque, NM.

Taken from Table 1 normal flow increases water from a confined aquifer enters repository subsidence fractures reach repository subsidence fractures end above repository

fluids recirculate in response to thermal gradients

fluids carry waste to wells or springs

fluids carry waste to rivers or tributaries

fluids recirculate in response to thermal gradients

water from the unconfined aquifer enters repository

fluids do not recirculate in response to thermal gradients

flow channels close and reopen later

head is below outfall

diffusive mixing occurs

head is above outfall

location of river channel changes and flow through repository is altered

location of river channel changes

ground-water flow paths are shortened

flux through repository is altered

fluids leave along new fault

permafrost affects repository 
6. Hunter, R.L., 1989. Events and Processes for Constructing Scenarios for the Release of Transuranic Waste From the Waste Isolation Pilot Plant, Southeastern New Mexico, SAND89-2546, Sandia National Laboratories, Albuquerque, NM.

Table 3.

dissolution other than leaching

migration of brine aquifer

breccia-pipe formation

migration of intracrystalline brine inclusions

induced diapirism

diffusion out of the respository

exhumation

sedimentation

faulting

glaciation

igneous intrusion

meteorite impact

sabotage

warfare

subsidence

themal effects

ground-water flow

climatic change

drilling into repository

effects of brine pocket

effects of mining for resources

seal performance

leaching

nuclear criticality

waste/rock interaction

gas generation waste effect

radiolysis waste effect 
7. International Atomic Energy Agency, 1983. Concepts and Examples of Safety Analyses for Radioactive Waste Repositories in Continental Geological Formations, Safety Series No. 58, International Atomic Energy Agency, Vienna, Austria.

Natural Processes and Events

climatic change

hydrology change

sea level change

denudation

stream erosion

glacial erosion

flooding

sedimentation

diagenesis

diapirism

faulting/seismicity

geochemical change

fluid interactions ground-water flow

dissolution

brine pockets

Uplift/subsidence

orogenic

epeirogenic

isostatic

Undetected features

faults, shear zones

breccia pipes

lava tubes

intrusive dykes

Magr.ıatic activity

gas or brine pockets

intrusive

extrusive

Meteorite impact

Human Activities

Faulty design

shaft seal failure

exploration bore-hole seal failure

Faulty operation

faulty waste emplacement

Transport agent introduction

irrigation

reservoirs

intentional artificial ground-water recharge or withdrawal

chemical liquid waste disposal

Large-scale alterations of hydrology

Undetected past intrusion

undiscovered boreholes

mine shafts 
Inadvertent future intrusion

exploratory drilling

archeological exhumation

resource mining (mineral, water, hydrocarbon, geothermal, salt, etc)

Intentional intrusion

war

sabotage

waste recovery

Climate control

Waste and Repository Effects

Thermal effects

differential elastic response

non-elastic response

fluid pressure, density, viscosity changes

fluid migration

Mechanical effects

canister movement

local fracturing

Chemical effects

corrosion

waste package-rock interactions

gas generation

geochemical change

Radiological effects

material property changes

radiolysis

decay-product gas generation

nuclear criticality 
8. Koplik, C.M., M.F. Kaplan, and B. Ross, 1982. "The Safety of Repositories for Highly Radioactive Wastes," Reviews of Modern Physics, Vol. 54, no. 1, p. 269-310.

Natural Phenomena

Climatic fluctuations

Glaciation

Denudation and stream erosion

Magmatic activity

extrusive

intrusive

Epeirogenic displacement igneous emplacement isostasy

Orogenic diastrophism near-field faulting far-field faulting diapirism diagenesis

Static fracturing surficial fissuring impact fracturing

Dissolutioning hydraulic fracturing

Sedimentation

Flooding

Undetected features

faults, shear zones

breccia pipes

lava tubes

Meteorites

gas or brine pockets

Waste and Repository Induced Phenomena

Thermal effects

differential elastic response

nonelastic response

fluid pressure changes

local fluid migration

canister migration

convection

Chemical effects

geochemical alterations

corrosion

waste package - geology interactions

gas generation

seal - rock interactions

Mechanical effects

change in local state of stress

readjustment of rock along joints

local fracturing

canister movement

subsidence of canister 
Radiation effects

material property changes

radiolysis

criticality

decay product gas generation stored energy

Modification of hydrologic regime

Human-Induced Phenomena

Improper design of operation shaft seal failure

improper waste emplacement

Undetected past intrusion undiscovered boreholes mine shafts

Inadvertent future intrusion archeological exhumation weapons testing non-nuclear waste disposal

resource mining (salt, mineral, hydrocarbon, geothermal) storage of hydrocarbons, compressed air, or hot water

Intentional intrusion

war

sabotage

waste recovery

Perturbation of ground-water system irrigation reservoirs intentional artificial ground-water recharge or withdrawal chemical liquid waste disposal

Biosphere alteration establishment of population center climate modification 
9. Merrett, G.J., and P.A. Gillespie, 1983. Nuclear Fuel Waste Disposal: Long-Term Stability Analysis, AECL-6820, Atomic Energy of Canada Limited, Pinawa, Manitoba.

Disruptive activities of man

drilling and mining

use of explosive devices

Vault-related events

excavation

presence of a heat source

stress analysis

fracture mechanics analysis

Presence of a radioactive source

Natural Phenomena

Glaciation

subsidence and rebound

glacially induced faulting

glacial erosion

Seismic activity

alteration of hydrological conditions

jointed rock motion

rapid fault growth

slow fault growth

new fault formation

Volcanic activity

hot-spot volcanic activity

rift system volcanic activity

Denudation and fluvial erosion

denudation

fluvial erosion

Meteorite impact

determination of impact frequencies

probability of damage

Biosphere changes 
10. Nuclear Energy Agency, 1992. Systematic Approach to Scenario Development. A Report of the NEA Working Group on the Identification and Selection of Scenarios for Performance Assessment of Radioactive Waste Disposal, Nuclear Energy Agency, Paris, France.

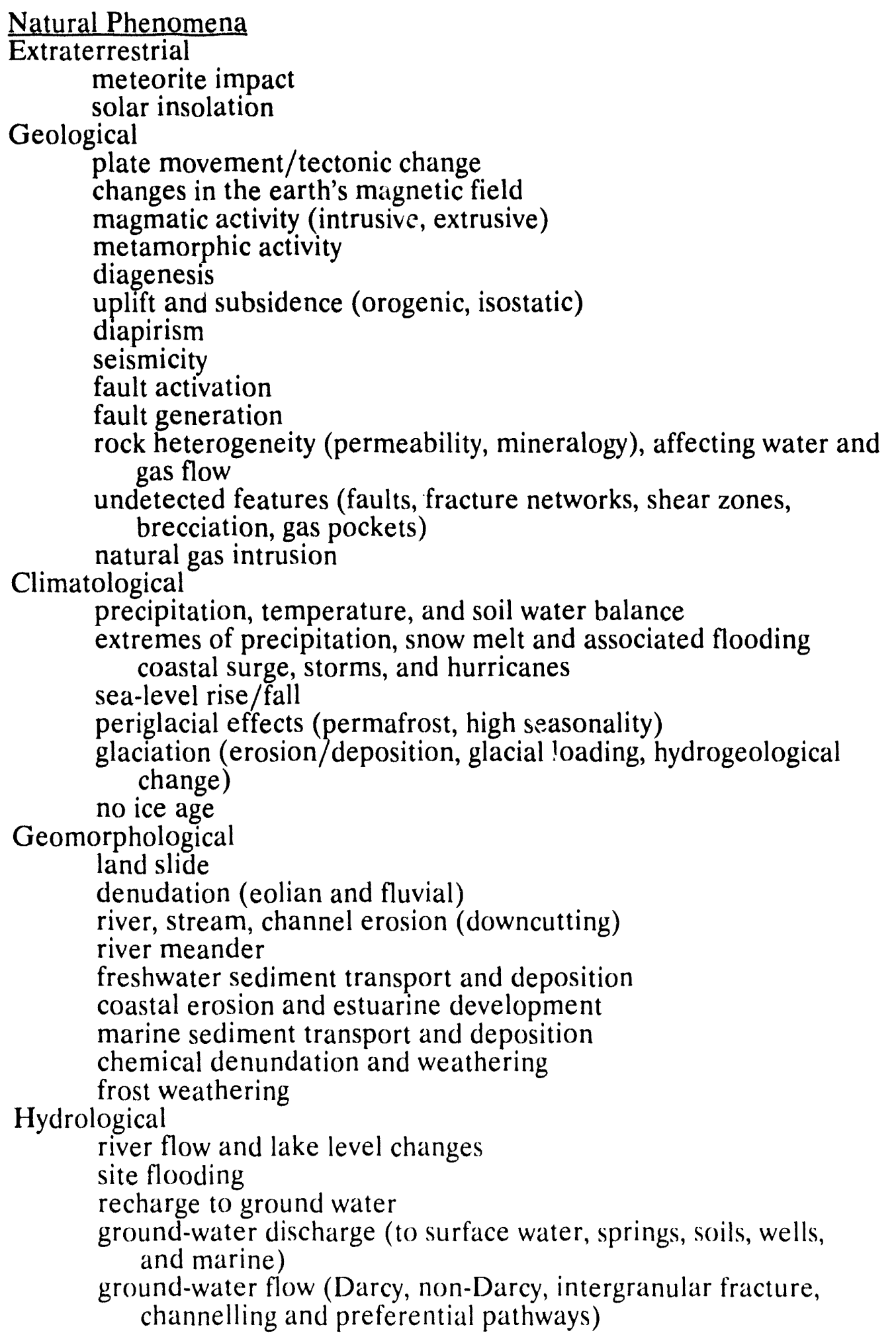




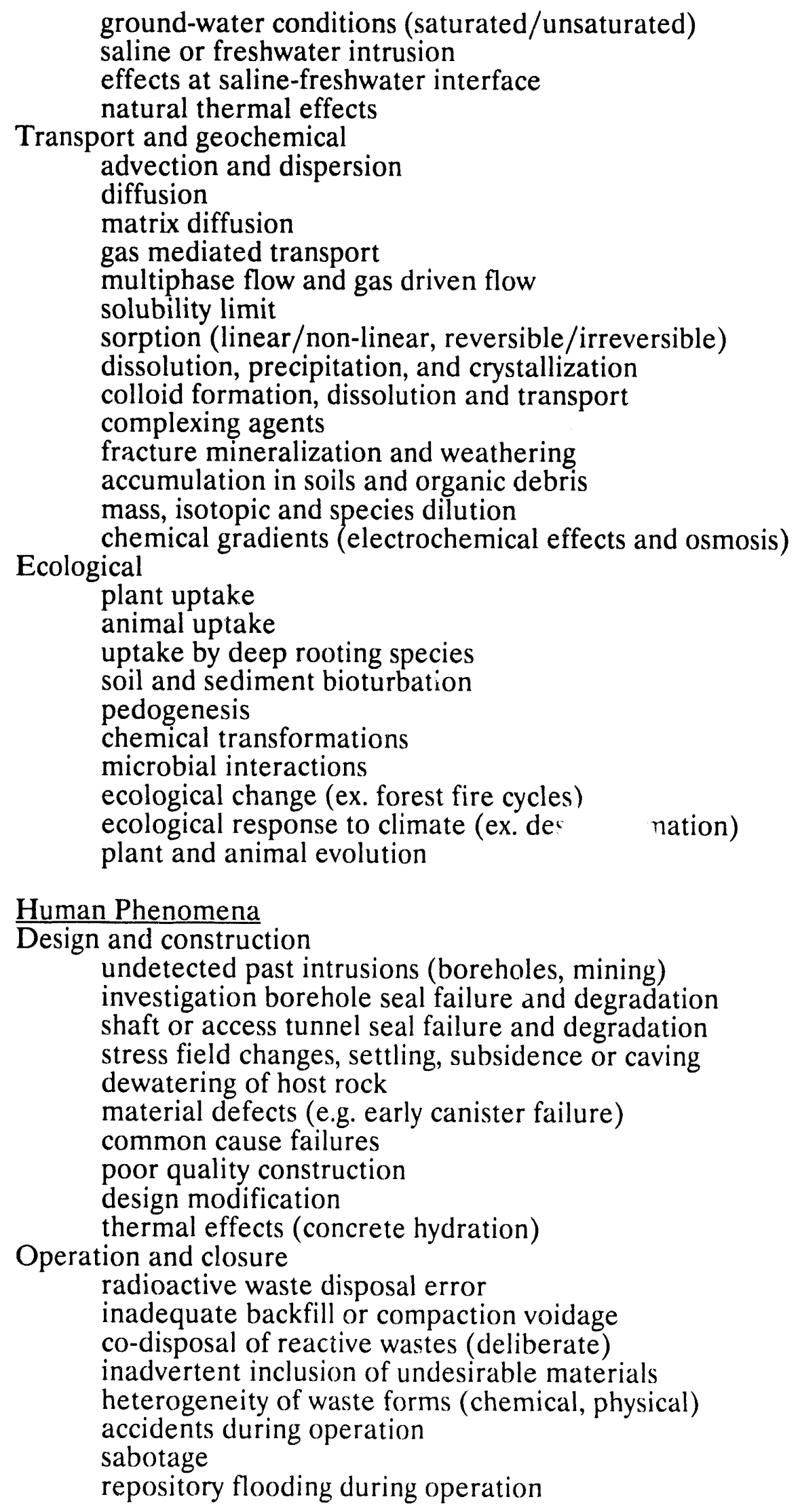

Human Phenomena

Design and construction undetected past intrusions (boreholes, mining) investigation borehole seal failure and degradation shaft or access tunnel seal failure and degradation stress field changes, settling, subsidence or caving dewatering of host rock material defects (e.g. early canister failure) common cause failures poor quality construction design modification thermal effects (concrete hydration)

Operation and closure radioactive waste disposal error inadequate backfill or compaction voidage co-disposal of reactive wastes (deliberate) inadvertent inclusion of undesirable materials heterogeneity of waste forms (chemical, physical) accidents during operation sabotage repository flooding during operation 
abandonment of unsealed repository

poor closure

post-closure monitoring

effects of phased operation

Post-closure subsurface activities (intrusion)

recovery of repository materials

malicious intrusion (sabotage, act of war)

exploratory drilling

exploitation drilling

geothermal energy production

resource mining

tunneling

underground construction

archeological investigation

injection of liquid wastes

ground-water abstraction

underground nuclear testing

Post-closure surface activities

loss of records

dams and reservoirs, built/drained

rivers rechanneled

irrigation

altered soil or surface water chemistry

land use changes

agricultural and fisheries practice changes

demographic change, urban development

anthropogenic climate changes (greenhouse effect)

quarrying, near surface extraction

\section{Waste and Repository Induced Phenomena}

Thermal (nuclear and chemical)

differential elastic response

non-elastic response

host rock fracture aperture changes

induced hydrological changes (fluid pressure, density convection, viscosity)

induced chemical changes (solubility sorption, species equilibrium

Chemical mineralization)

metallic corrosion (pitting/uniform, internal and external agents, gas generation e.g. H2)

interactions of host materials and ground water with repository material (ex. concrete carbonation, sulphate attack)

interactions of waste and repository materials with host materials

(electrochemical corrosive agents)

non-radioactive solute plume in geosphere (effect on redox, ph and sorption)

cellulosic degradation

introduced complexing agents and cellulosics

microbiological (effects on corrosion/degradation, solubility/complexation, gas generation, ex. $\mathrm{CH}_{4} \mathrm{CO}_{2}$ ) 


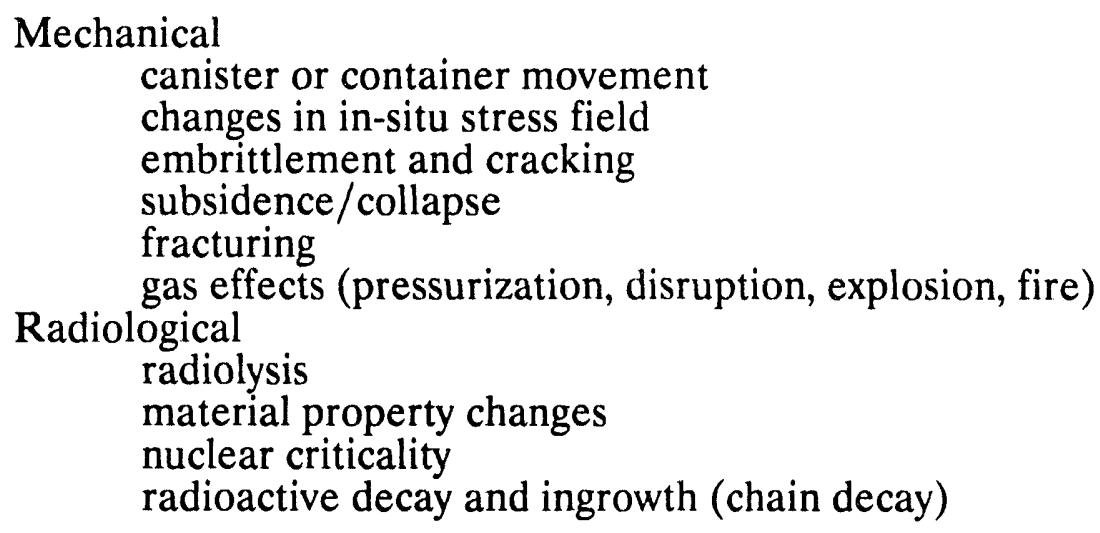


11. Prij, J., B. Blok, D. Fraters, P. Glasbergen, G.M.H. Laheij, W. Slagter, A.F.M. Slot, P. Uijt de Haag, H. Van de Weerd, A.F.B. Wildenborg, and B. Zanstra. 1991. PROSA PRobablistisch Onderzoek aan de veiligheid van in Steenzout opgeborgen radioactief Afval, Concept Tussenrapport 4, Scenario Selectie, Energieonderzoek Centrum, Nederland, Petten, the Netherland.

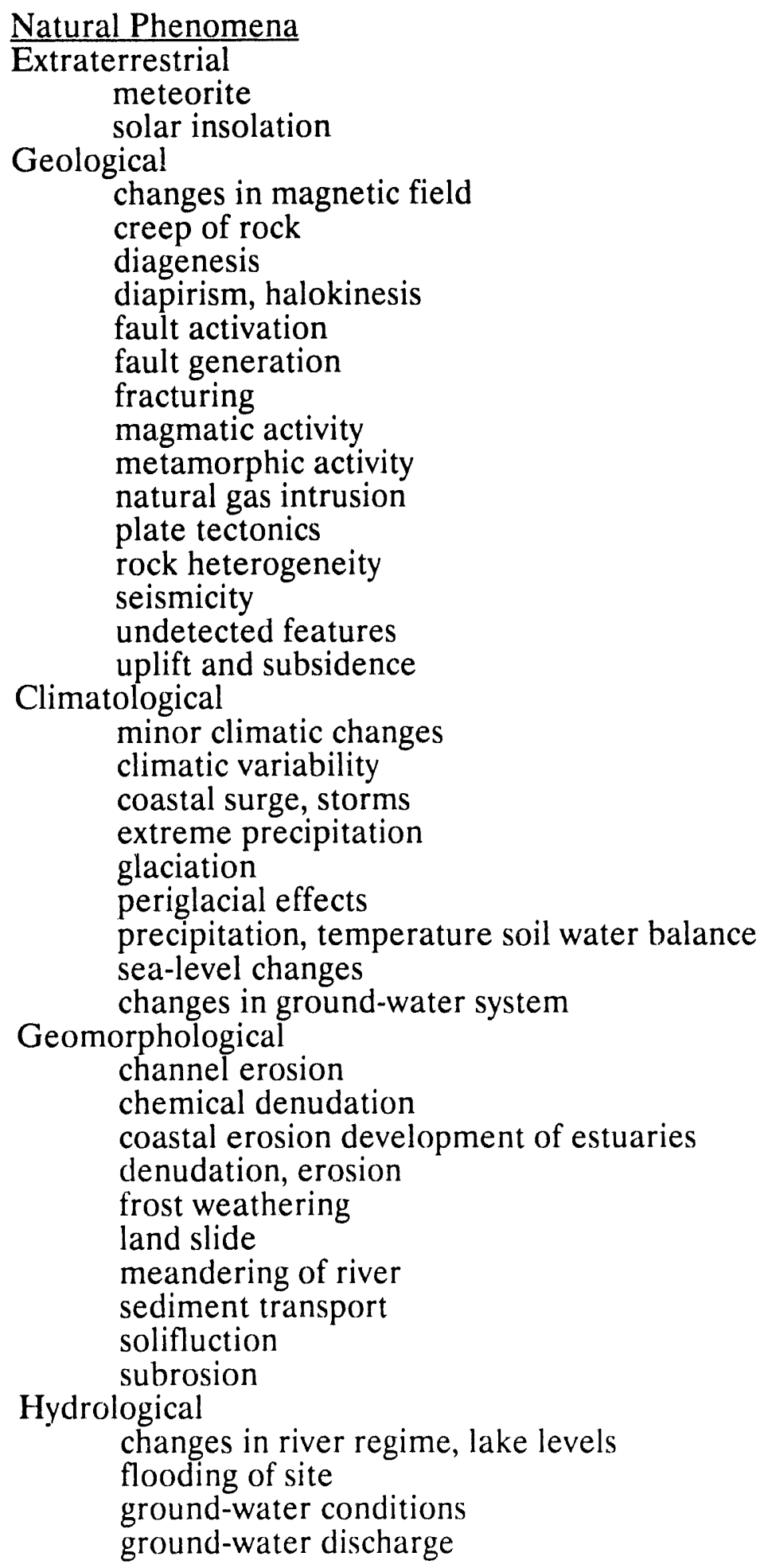




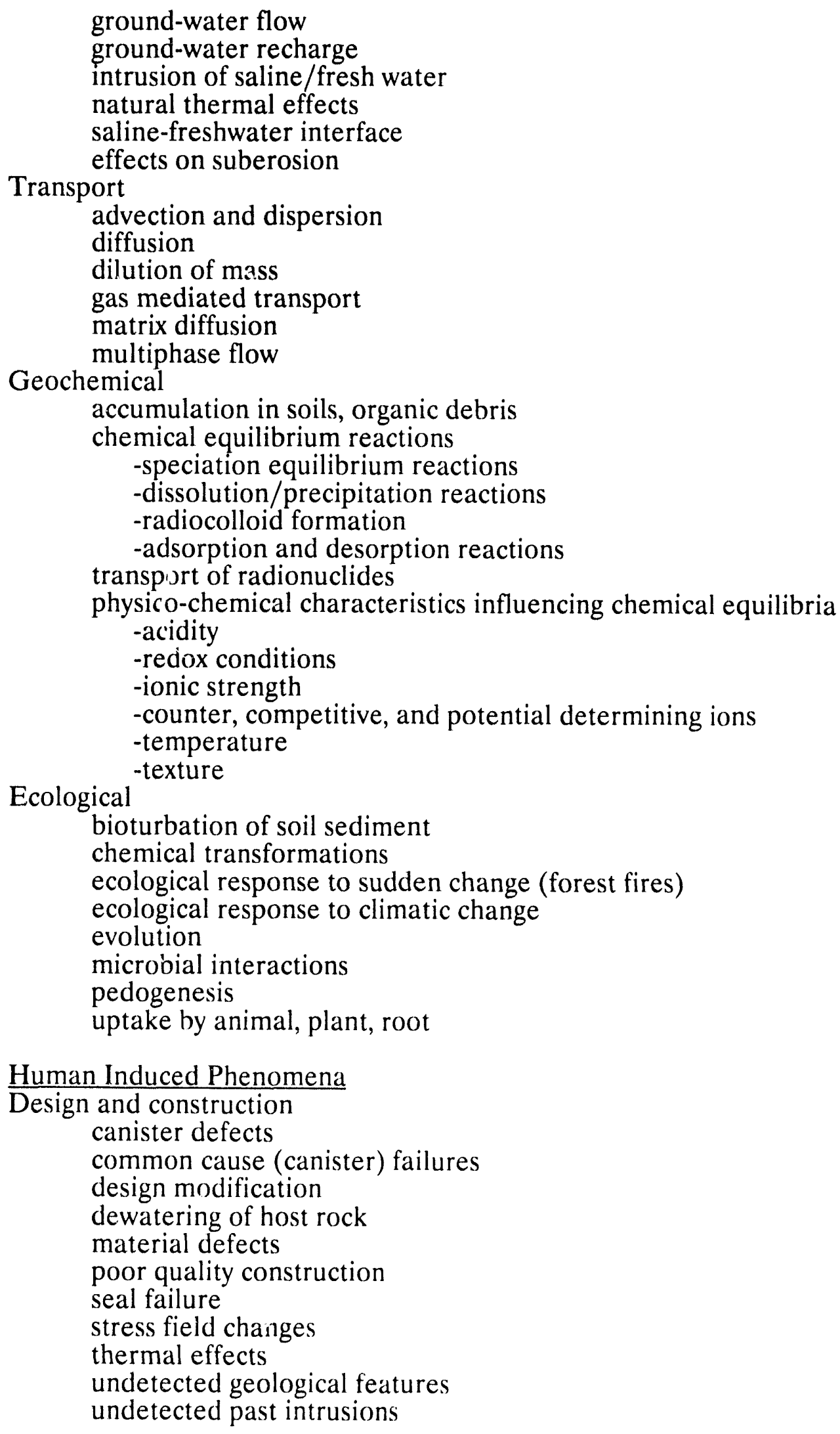

Human Induced Phenomena

Design and construction canister defects common cause (canister) failures design modification dewatering of host rock material defects poor quality construction seal failure stress field changes thermal effects undetected geological features undetected past intrusions 
Operation and closure abandonment of unsealed repository accidents during operation co-disposal of reactive wastes (deliberate) flooding of repository during operation heterogeneity of waste forms; chemical or physical improper waste emplacement inadequate backfill compaction, voidage inadvertent inclusion of undesirable materials phased operation effects poor closure post-closure monitoring radioactive waste disposal error sabotage

Post-closure sub-surface activities archaeological investigation attempt of site improvement exploitation drilling exploratory drilling geothermal energy production ground-water abstraction/recharge injection of fluids malicious intrusion, sabotage/war recovery of repository materials resource mining tunneling underground construction underground nuclear testing water table changes

Post-closure surface activities alteration of soil, surface water chemistry anthropogenic climate changes (greenhouse effect) changes in land use construction of dams/reservoirs agricultural developments and changes fisheries developments and changes demographic developments and changes urban developments and changes drainage of dams reservoirs irrigation loss of records quarrying, surface mining rechannelling of rivers

Waste and Repository Induced Phenomena

Thermal

brine migration

canister migration

dehydration of salt minerals

differential elastic response

fracture aperture changes

induced chemical changes 


\author{
Chemical \\ cellulosic degradation \\ degradation of buffer/backfill \\ electrochemical reactions \\ gas generation, explosions \\ geochemical alterations \\ introduced complexing agents, cellulosics \\ leaching of nuclides \\ material interactions \\ metallic corrosion \\ microbiological effects \\ non-radioactive solute in geosphere \\ Mechanical \\ redox potential, $\mathrm{pH}$ \\ canister or container movement \\ changes in in-situ stress field \\ convergence of openings \\ embrittlement, cracking \\ fracturing \\ gas generation effects \\ readjustment of host rock along joints \\ subsidence, collapse \\ swelling of backfill (clay) \\ swelling of corrosion products \\ Radiological \\ heat production \\ material property changes \\ nuclear criticality \\ radioactive decay/ingrowth \\ radiolysis \\ release of stored energy
}

induced hydrological changes

non-elastic response 
APPENDIX C

FEATURES, EVENTS, AND PROCESSES (FEPS)

CONSIDERED FOR THE GCD LOCATION

C-1 


\section{REVISED LIST OF FEPS USED IN SCREENING}

1.0 Naturally Occurring Phenomena

1.1 Geologic FEPs

1.1.1 Accumulation of gases under permafrost

1.1.2 Changes in magnetic field

1.1.3 Creep of rocks

1.1.4 Dam \& reservoir formation from natural causes

1.1.5 Dissolution

1.1.6 Erosion/sedimentation

1.1.7 Fault activation

1.1.8 Fault generation

1.1.9 Faults/shear zones

1.1.10 Formation of interconnected fracture systems

1.1.11 Frost erosion

1.1.12 Gas or brine pocket

1.1.13 Glacial erosion

1.1.14 Glacially induced faulting

1.1.15 Glaciation

1.1.16 Halokinesis

1.1.17 Ingeous emplacement

1.1.18 Jointed-rock movement

1.1.19 Lava tubes

1.1.20 Mass wasting/landslides

1.1.21 Metamorphic activity

1.1.22 Natural-gas intrusion

1.1.23 Pedogenesis

1.1.24 Regional [epeirogenic] uplift and subsidence

1.1.25 Rock [sediment] heterogeneity

1.1.26 Sea-level variations

1.1.27 Seiches

1.1.28 Seismic activity

1.1.29 Solifluction

1.1.30 Tsunamis

1.1.31 Undetected discontinuities

1.1.32 Undetected geologic features

1.1.33 Volcanic activity

1.2 Hydrologic FEPs

1.2.1 Ad _ction and dispersion

1.2.2 Alttration of hydrologic conditions

1.2.3 Changes in river regime/lake levels 


\subsubsection{Effects of saline-freshwater interface}

1.2.5 Flooding of site

1.2.6 Fluids carry waste to rivers or tributaries

1.2.7 Fluids carry waste to wells or springs

1.2.8 Fluids leave along new faults

1.2.9 Flux through repository

1.2.10 Gas mediated transport

1.2.11 Geothermally-induced flow

1.2.12 Ground-water conditions (saturated/unsaturated)

1.2.13 Ground-water discharge to surface water

1.2.14 Ground-water flow (Darcy, nondarcy, intergranular fracturing)

1.2.15 Ground-water flow paths are shortened

1.2.16 Ground-water recharge

1.2.17 Head is above outfall

1.2.18 Head is below outfall

1.2.19 Infiltration and evapotranspiration

1.2.20 Migration of brine aquifer

1.2.21 Multiphase flow and gas-driven flow

1.2.22 Stress changes of conductivity

1.2.23 Thermal effects of ground-water flow

1.2.24 Transport of radionuclides

\subsection{Geochemical FEPs}

1.3.1 Accumulation in soils and organic debris

1.3.2 Chemical equilibrium reactions

1.3.3 Chemical gradients (electrochemical effects and osmosis)

1.3.4 Colloid dissolution

1.3.5 Colloid formation

1.3.6 Colloid transport

1.3.7 Complexing agents

1.3.8 Crystallization

1.3.9 Diagenesis

1.3.10 Dissolution other than leaching

1.3.11 Fracture mineralization and weathering

1.3.12 Geochemical changes from natural causes

1.3.13 Mass, isotopic, and species dilution

1.3.14 Matrix diffusion

1.3.15 Natural electrochemical reactions

1.3.16 Physico-chemical characteristics influencing chem. equilibrium

1.3.17 Weathering of flow paths 


\subsection{Climatic FEPs}

1.4.1 Changes in ground-water [flow]

1.4.2 Climatic change

1.4.3 Coastal surge, storms

1.4.4 High seasonality

1.4.5 Hurricanes

1.4.6 No ice age

1.4.7 Periglacial effects

1.4.8 Permafrost

1.4.9 Precipitation, temperature, soil-water balance

1.4.10 Tornados

\subsection{Ecological FEPs}

1.5.1 Animal intake

1.5.2 Bioturbation of soil sediments

1.5.3 Chemical transformations

1.5.4 Ecological response to climatic change

1.5.5 Evolution

1.5.6 Microbial interactions

1.5.7 Plant uptake

\subsection{Extraterrestial FEPs}

1.6.1 Determination of impact frequencies

1.6.2 Impact fracturing

1.6.3 Meteorite impact

1.6.4 Probability of damage

1.6.5 Solar insolation

2.0 Human-Induced Phenomena

2.1 Operation and Closure FEPs

2.1.1 Abandonment of poorly or unsealed repository

2.1.2 Accident during operation

2.1.3 Costorage of other wastes

2.1.4 Phased-operation effects

2.2 Postclosure Surface FEPs

2.2.1 Anthropogenic climatic changes

2.2.2 Changes in land use

2.2.3 Chemical sabotage 
2.2.4 Construction of dams/reservoirs

2.2.5 Explosions

2.2.6 Fisheries development and changes

2.2.7 Irrigation

2.2.8 Loss of records

2.2.9 Quarrying, near surface

2.2.10 Rechanneling of rivers

2.3 Postclosure Subsurface FEPs

2.3.1 Altered surface-water chemistry by humans

2.3.2 Archeological exhumation

2.3.3 Attempt at site improvement

2.3.4 Change in ground-water chemistry in nearby rocks

2.3.5 Drilling of withdrawal/injection wells

2.3.6 Earthquake from man-made causes

2.3.7 Exploratory drilling for resources

2.3.8 Geothermal energy production

2.3.9 Malicious intrusion, sabotage/war

2.3.10 Postclosure monitoring

2.3.11 Recovery of repository material

2.3.12 Resource mining

2.3.13 Reuse of boreholes

2.3.14 Storage of hydrocarbons, compressed air, hot water

2.3.15 Subsidence due to ground-water withdrawal

2.3.16 Tunneling

2.3.17 Underground construction

2.3.18 Underground nuclear testing

2.3.19 Undetected past boreholes

3.0 Waste- and Repository-Induced Phenomena

3.1 Chemical FEPs

3.1.1 Backfill effects on $\mathrm{Cu}$ corrosion

3.1.2 Chemical reactions

3.1.3 Chemical toxicity of waste

3.1.4 Colloid generation source

3.1.5 Coupled effects

3.1.6 Creeping of copper

3.1.7 Decay product gas generation

3.1.8 Electrochemical reactions

3.1.9 Fire and explosion of waste after burial

3.1.10 I-Cs migration to fuel surface 
3.1.11 Introduced complexing agent

3.1.12 Leaching of radionuclides

3.1.13 Microbial effects

3.1.14 Near-field buffer chemistry

3.1.15 Nonradioactive solute in geosphere

3.1.16 Nuclear criticality

3.1.17 Oxidizing conditions

$3.1 .18 \mathrm{pH}$ deviations

3.1.19 Pitting

3.1.20 Reconcentraiton

3.1.21 Recrystallization

3.1.22 Redox front

3.1.23 Redox potential

3.1.24 Release of radionuclides from failed canister

3.1.25 Solubility limit

\subsection{Thermal FEPs}

3.2.1 Brine migration

3.2.2 Convection

3.2.3 Dehydration of salt minerals

3.2.4 Differential elastic response

3.2.5 Fluid migration

3.2.6 Fluid pressure, density, viscosity changes

3.2.7 Fracture aperture changes

3.2.8 Heat production (by radioactive decay)

3.2.9 Induced hydrologic changes

3.2.10 Internal pressure

3.2.11 Migration of intracrystalline brine inclusions

3.2.12 Nonelastic response

3.2.13 Thermal changes in burial zone caused by heat generation

3.2.14 Thermal cracking

3.2.15 Thermal effects

3.2.16 Thermal effects on buffer material

3.2.17 Thermochemical changes

\subsection{Mechanical FEPs}

3.3.1 Canister defects

3.3.2 Canister or container movement

3.3.3 Changes in in-situ stress field

3.3.4 Convergence of openings

3.3.5 Damaged or deviating fuel

3.3.6 Degradation of borehole and/or shaft seals 


\subsubsection{Design modifications}

3.3.8 Dewatering of host rock [sediments]

3.3.9 Embrittlement, cracking

3.3.10 Fracturing

3.3.11 Loss of ductility

3.3.12 Material defects

3.3.13 Mechanical failure of buffer/backfill

3.3.14 Mechanical failure of repository

3.3.15 Readjustment of rock along joints

3.3.16 Role of eventual channeling within canister

3.3.17 Stress corrosion cracking

3.3.18 Subsidence of canister

3.3.19 Subsidence or caving

3.3.20 Sudden energy release

3.3.21 Swelling of backfill

3.3.22 Swelling of bentonite into tunnels and cracks

3.3.23 Swelling of corrosion products

3.4 Radiological FEPs

3.4.1 Material property change

3.4.2 Radiation effects on bentonite

3.4.3 Radiation effects on canister

3.4.4 Radioactive decay and ingrowth

3.4.5 Radiolysis

3.4.6 Recoil of alpha decay

3.4.7 Release of stored energy

3.5 Improper Design and Operation FEPs

3.5.1 Backfill material deficiencies

3.5.2 Coagulation of bentonite

3.5.3 Improper waste emplacement

3.5.4 Sedimentation of bentonite 
DISPOSITION OF FEATURES, EVENTS, AND PROCESSES

AS A RESULT OF SCREENING

D-1 


$$
\text { D-2 }
$$




\subsection{NATURALLY OCCURRING PHENOMENA}

\subsection{GEOLOGIC FEPs}

\subsubsection{FEP Name: ACCUMULATION OF GASES UNDER PERMAFROST}

Screening Criterion: Physical reasonableness

Disposition: Screened out from scenario development

Discussion: The GCD region has not been subjected to either alpine or continental glaciation since at least the beginning of Paleozoic time. A change in geologic and/or climatic conditions that would result in glaciation at this location within the next 10,000 years is not physically reasonable.

\subsubsection{FEP Name: CHANGES IN MAGNETIC FIELD}

Screening Criterion: Base-case condition

Disposition: Part of base-case scenario

Discussion: In addition to the periodic reversal of the magnetic field, the geographic location of the magnetic poles is from a practical standpoint continuously changing. Although the probability of magnetic reversals occurring is less than 1 , the probability of changes in the magnetic field orientation during the period of regulatory concern is 1 . With a probability of 1 , this process is a basecase condition, although no consequences from changes in field orientation have been identified.

\subsubsection{FEP Name: CREEP OF ROCKS}

Screening Criterion: Applicability to geologic setting

Disposition: Screened out from scenario development

Discussion: For this process, "creep" refers to the deformation of solid rock without brittle failure in response to the imposed differential stress field. By this definition, creep cannot occur in unconsolidated basin-fill and alluvial-fan sediments. For the GCD location, the pressure-temperature regime for the underlying Paleozoic rocks is not suitable for rock creep to occur. 


\subsubsection{FEP Name: DAM \& RESERVOIR FORMATION FROM NATURAL CAUSES}

Screening Criterion: Physical reasonableness

Disposition: Screened out from scenario development

Discussion: Dam and reservoir formation by natural causes requires mass wasting to block a drainage channel and a sufficiently large depression up gradient from the dam for water to accumulate. The GCD is located on an alluvial fan where flow in channels is ephemeral, channels are incised with no flood plain, and the topographic relief is low. None of these conditions are suitable for the formation of dams and reservoirs. Changes in the current conditions that would allow for standing water to accumulate on an alluvial fan are not physically reasonable within the time frame of regulatory concern.

Damming of Scarp Canyon has been suggested as a possibility, although the physical setting south of the Massachusetts Mountains precludes a long-term occurrence of this type. Collapse of the channel banks into the channel will not fill the channel. Water that may backup behind such a dam will be confined to the channel and will quickly overflow the dam and erode the unconsolidated material of the dam. As a result, any such occurrence will be of short duration and of no consequence to performance of the disposal system in the unsaturated zone.

\subsubsection{FEP Name: DISSOLUTION}

Screening Criterion: Sediments and sedimentary rocks--applicability to geologic setting; Paleozoic imestone--base-case condition

Disposition: Sediments and sedimentary rocks--screened out from scenario development; Paleozoic limestone--part of base case

Discussion: The sediments and sedimentary rocks are of compositions that are not subject to dissolution on an appreciable scale. For the Paleozoic limestone, dissolution over a long-term time scale has occurred to widen the fracture apertures. No effects of dissolution of the limestone on the overlying units in the $G C D$ region have been reported.

\subsubsection{FEP Name: EROSION/SEDIMENTATION}

Screening Criterion: Base-case conditions 


\section{Disposition: Part of base-case scenario}

Discussion: The probability of erosion and sedimentation occurring on an active alluvial fan is 1 . Because $P=1$, these processes are part of base-case conditions. The possible effects of erosion and sedimentation on the performance of the disposal system are being investigated.

\subsubsection{FEP Name: FAULT ACTIVATION}

\section{Screening Criterion: Physical reasonableness}

Disposition: Screened out from scenario development

Discussion: Fault activation refers to renewed movement on existing faults. Surface expressions of faults are present in the highlands surrounding Frenchman Flat (see Figure 1, Appendix E; Case et al., 1984; Hudson, 1992). Faults may be present beneath the basin-fill deposits of Frenchman Flat and may extend into the basin-fill deposits in the northern portion of the Flat, although no surface expression of faulting has been reported within the sediments of Frenchman Flat. Questions arise whether faults are likely to intersect the GCD boreholes and what effect movement on faults would have on disposal- system performance.

Mapping efforts of GCD boreholes and trenches within the RWMS have not identified fault zones within the basin-fill deposits (RSN, 1991; Gustafson et al., 1993b; Snyder et al., 1993). This lack of faults can be the result of either faulting not having been an active process within this portion of Frenchman Flat or the deformational stresses have not built up to a level where faulting has occurred since the deposition of the sediments examined in the mapping activities. This latter conceptual model would not necessarily preclude faulting from occurring in the relatively near future.

The estimated ages of the sediments mapped suggest that if faults exist beneath the GCD facility, movement along these faults has not occurred over a relatively long time period considering the seismic activity in the area (see Appendix F). Unpublished age dates obtained by the U.S. Geological Survey for a basalt flow within the basin-fill deposits in Frenchman Flat produced an age of approximately 8.6 million years for samples from a depth of 700 feet (Rawlinson, 1993). This age and depth indicate an average rate of subsidence, and presumably deposition, of $8 \times 10^{-5}$ feet/year. An age date for an ash bed at a depth of 195 meters (640 feet) within the basin-fill deposits was estimated to be within the range 2.5 to 2.9 million years old (Izett et al., 1988). These ages and depth indicate an average rate of subsidence and deposition of $2.6 \times 10^{-4}$ to $2.2 \mathrm{x}$ 
$10^{-4}$ feet/year. Radiocarbon dates on samples from pits at the RWMS and uranium-series dates on caliche in these pits result in an estimated age of 143,000 years for the sediments at the bottom of the pits (RSN, 1991). The pit depth was not specified, but based on stratigraphic sections developed by RSN (1991, p. 19), the depth for this age is in the 7-to 8-meter (23- to 26-foot) range. This age and depths indicate an average rate of subsidence and deposition of 1.6 $\times 10^{-4}$ to $1.8 \times 10^{-4}$ feet/year. From a practical viewpoint given the various sources of uncertainty in these estimations, these rates of subsidence and deposition are basically the same, with a mean value of $2 \times 10^{-4} \mathrm{feet} / \mathrm{year}$.

If the sediments at a GCD-borehole location were deposited at this mean rate, the sediments at the bottom of a borehole (120 feet deep) would be approximately 600,000 years old. For faults at depth (if any exist) whose plane of projection would intersect a GCD borehole if movement along the fault were to occur, any significant displacement could not have occurred within the last 600,000 years or evidence for the fault could be seen in the walls of the borehole. Given the relatively high rate of seismic activity in the region (see Appendix F), such a duration of inactivity is unlikely. The same line of reasoning is applicable to the pits and trenches, although the duration of faulting inactivity would be less (approximately 143,000 years at a minimum).

Based on the relatively long time periods during which sediments were deposited in a seismically active area without being intersected by one or more faults at the GCD location, "active" faults beneath the GCD facility and the RWMS can be concluded not to exist. Changes in the local stress field to an extent that currently inactive faults (if any are present) would become active within the time frame of regulatory concern are not physically reasonable.

\subsubsection{FEP Name: FAULT GENERATION}

Screening Criterion: Physical reasonableness

Disposition: Screened out from scenario development

Discussion: Movement on faults to relieve stresses in the Earth's crust typically occurs along existing faults. The formation of a new fault within an area of existing faults is a rare event (Bonilla, 1979). A change in the orientation of the stress field in the Frenchman Flat area that would require the formation of one or more new faults to relieve the accumulating stress is not physically reasonable within the time frame of regulatory concern. 


\subsubsection{FEP Name: FAULTS, SHEAR ZONES}

Screening Criterion: Part of conceptual model

Disposition: Screened out from scenario development

Discussion: Recognized geologic features are part of the disposal system, and therefore are part of the conceptual model of the disposal system.

\subsubsection{FEP Name: FORMATION OF INTERCONNECTED FRACTURE SYSTEMS}

Screening Criterion: Physical reasonableness

Disposition: Screened out from scenario development

Discussion: Those units subject to fracturing are already fractured. Changes in the stress regime within the time frame of interest to an extent that would generate new fracture systems are not physically reasonable.

\subsubsection{FEP Name: FROST WEATHERING}

Screening Criterion: Consequence

Disposition: Screened out from scenario development

Discussion: "Frost weathering" presumably refers to the physical weathering caused by the formation and melting of ice crystals between mineral grains or crystals. This type of weathering is confined to surficial and near-surface materials. This process will not affect the overall performance of the disposal system, especially with the presence of unconsolidated to weakly consolidated valley-fill sediments at the GCD location.

\subsubsection{FEP Name: GAS OR BRINE POCKET}

Screening Criterion: Applicability to geologic setting

Disposition: Screened out from scenario development

Discussion: Basin-fill and alluvial-fan deposits are not suitable host materials for the accumulation of brine or gases. Underlying Paleozoic and Precambrian rocks are not suitable hosts for brine pockets. Pockets of natural gas in Paleozoic units are considered under the heading of Exploratory Drilling. 


\subsubsection{FEP Name: GLACIAL EROSION}

Screening Criterion: Physical reasonableness

Disposition: Screened out from scenario development

Discussion: Southern Nevada has not been subjected to continental glaciation and the GCD region has not been subjected to either continental or alpine glaciation since at least the beginning of Paleozoic time. A change in geologic and/or climatic conditions that would result in glaciation at this location within the next 10,000 years is not physically reasonable.

\subsubsection{FEP Name: GLACIALLY INDUCED FAULTING}

Screening Criterion: Physical reasonableness

Disposition: Screened out from further consideration

Discussion: The GCD region has not been subjected to either alpine or continental glaciation since at least the beginning of Paleozoic time. A change in geologic and/or climatic conditions that would result in glaciation at this location within the next 10,000 years is not physically reasonable.

\subsubsection{FEP Name: GLACIATION}

Screening Criterion: Physical reasonableness

Disposition: Screened out from scenario development

Discussion: The GCD location has not been subjected to either alpine or continental glaciation since at least the beginning of Paleozoic time. A change in geologic and/or climatic conditions that would result in glaciation at this location within the next 10,000 years after such a long period of time without glaciation is not physically reasonable.

1.1.16 FEP Name: HALOKINESIS [salt tectonics; diapirism]

Screening Criterion: Applicability to geologic setting

Disposition: Screened out from scenario development 
Discussion: The stratigraphic section at this location does not contain any units composed entirely or predominantly of salt, which are required for halokinesis to occur.

\subsubsection{FEP Name: IGNEOUS EMPLACEMENT [plutonic activity]}

Screening Criterion: Physical reasonableness

Disposition: Screened out from scenario development

Discussion: Plutonic igneous rocks are exposed at three locations in northern NTS (Figure F-1). These quartz-monzonite stocks have been dated as Mesozoic in age with none of these age dates less than 89 million years (Appendix F). Because of the length of time since the intrusion of these stocks and the lack of seismic activity or geothermal conditions that can be associated with the movement or presence of magma at depth, a change in the geologic conditions to an extent that magma bodies would intrude into the region where the performance of the GCD disposal system could be affected within the time frame of regulatory concern is not physically reasonable.

\subsubsection{FEP Name: JOINTED-ROCK MOTION}

Screening Criterion: Applicability to geologic setting

Disposition: Screened out from scenario development

Discussion: Except for the possibility of locations close to fault zones, the alluvial-fan deposits do not contain joints (fractures). No evidence has been cited in the open literature that movement on joint systems occurs in the underlying Tertiary, Paleozoic, and Precambrian rocks, except in the proximity of fault zones. Movement along fractures associated with faults is considered in Fault Activation/Fault Generation under the heading of Geologic FEPs.

\subsubsection{FEP Name: LAVA TUBES}

Screening Criterion: Part of conceptual model

Disposition: Screened out from scenario development

Discussion: Lava tubes have not been identified as present in any of the volcanic units beneath the alluvial-fan and basin-fill deposits in southeastern NTS. 


\subsubsection{FEP Name: MASS WASTING/LANDSLIDES}

Screening Criterion: Base-case condition

Disposition: Part of base-case scenario

Discussion: Mass wasting is certain to occur on an alluvial fan, although the low topographic relief on the fan where GCD is located will limit this process to very small-scale collapses along the banks of some channels. Small-scale collapses will be washed away by water flowing in the channels within relatively short time intervals. Mass wasting will not affect the performance of the disposal system. The topographic relief on the alluvial fan is not large enough for landslides of significant scale to occur.

\subsubsection{FEP Name: METAMORPHIC ACTIVITY}

Screening Criterion: Applicability to geologic setting

Disposition: Screened out from scenario development

Discussion: The pressures and temperatures required for regional metamorphism to occur do not exist in the suprabasement rock and sediments. The presence of a Paleozoic limestone on a regional scale (Winograd and Thordarson, 1975) indicates that metamorphism has not and is not occurring in the suprabasement rocks and sediments. Possible contact metamorphism caused by the heat from feeder dikes of volcanic centers should be considered with Volcanism rather than Metamorphism.

\subsubsection{FEP Name: NATURAL-GAS INTRUSION}

Screening Criterion: Applicability to geologic setting

Disposition: Screened out from scenario development

Discussion: No evidence has been noted during site-characterization that natural gas is migrating through either the saturated or unsaturated units at the GCD location.

\subsubsection{FEP Name: PEDOGENESIS}

Screening Criterion: Base-case condition

Disposition: Part of base-case scenario 
Discussion: Pedogenesis is a continuously ongoing process, although a rock or sediment surface may not be exposed for a long enough period of time for a recognizable soil to develop. Possible consequences of soil development need to be identified to determine whether soils that develop during the time period of regulatory concern can affect the performance of the disposal system.

\subsubsection{FEP Name: REGIONAL [Epeirogenic] UPLIFT AND SUBSIDENCE}

Screening Criterion: Base-case condition

Disposition: Part of the base-case scenario

Discussion: Naturally occurring seismic activity in the Frenchman Flat area, as is the case in most areas, is primarily the result of displacement along faults. The presence of Quaternary faults in the Frenchman Flat area (Appendix E) and the continuing seismic activity in the same area indicates that tectonic activity is an ongoing process. As an ongoing process, tectonic activity is part of the base-case conditions.

\subsubsection{FEP Name: ROCK [SEDIMENT] HETEROGENEITY}

Screening Criterion: Part of conceptual model

Disposition: Screened out from scenario development

Discussion: Heterogeneity of geologic and hydrologic properties of the various stratigraphic units are included in the conceptual model of the disposal system. An alternative approach is to assume homogeneity of the medium if this assumption produces conservative results (see Price et al., 1993a).

\subsubsection{FEP Name: SEA-LEVEL VARIATIONS}

Screening Criterion: Physical reasonableness

\section{Disposition: Screened out from scenario development}

Discussion: Changes in sea level are the result of (1) climatic changes adding to or reducing the amount of water in the ocean basins primarily through increases or decreases in the size of continental glaciers, (2) eustatic changes in response to the load upon the crust, and/or (3) tectonic activity. The GCD is located at an elevation greater than 3,000 feet (915 meters) and at a distance of more than 275 miles (442 kilometers) from the nearest ocean, which precludes the location 
from being inundated from the melting of the world's glaciers. Eustatic and tectonic contributions to sea-level changes that could result in the inundation of the disposal location are not physically reasonable within the time frame of regulatory concern.

\subsubsection{FEP Name: SEICHES}

Screening Criterion: Physical reasonableness

Disposition: Screened out from scenario development

Discussion: A seiche is a "free or standing-wave oscillation of the surface of water in an enciosed or semi-enclosed basin...that is initiated chiefly by local changes in atmospheric pressure, aided by winds, tidal currents, and small earthquakes; and that continues, pendulum fashion, for a time after cessation of the originating force" (Bates and Jackson, 1987, p. 600). Seiches range in height from several centimeters to a few meters. The location of the GCD facility is far enough from any large body of water for the mechanism to generate seiches of sufficient size to reach this location to be physically unreasonable.

\subsubsection{FEP Name: SEISMIC ACTIVITY}

Screening Criterion: Base-case condition

Disposition: Part of base-case scenario

Discussion: A discussion of the historical seismic activity of the NTS region of both naturally occurring and human-induced origins is included in Appendix F of this report. Based on the available data, seismic activity caused by naturally occurring events has been and continues to be common in the NTS region. For the time frame of regulatory concern, the probability of seismic activity in this region is 1 . Because of the certainty of occurrence, seismic activity is part of the base-case conditions.

\subsubsection{FEP Name: SOLIFLUCTION}

Screening Criterion: Applicability to geologic setting

Disposition: Screened out from scenario development

Discussion: Solifluction is the down-slope flow of water-logged soil and/or other saturated surficial materials (Bates and Jackson, 1987). Because of the lowangle slopes on the alluvial fan in the GCD area and the short-duration of the 
near-surface saturated conditions, solifluction either is not occurring in this area or is occurring at such a small scale as to be insignificant when compared to other geomorphic processes.

\subsubsection{FEP Name: TSUNAMIS}

Screening Criterion: Physical reasonableness

Disposition: Screened out from scenario development

Discussion: A tsunami is a "gravitational sea wave produced by any large-scale, short-duration disturbance of the ocean floor, principally by a shallow submarine earthquake, but also by submarine earth movement, subsidence, or volcanic eruption" (Bates and Jackson, 1987, p. 704). The GCD facility is located more than 275 miles (442 kilometers) from the nearest ocean and is located at an elevation of approximately 3,200 feet (975 meters). An occurrence of a geologic disturbance on a scale that would result in a tsunami large enough to inundate a major part of a continent (from any ocean to at least the GCD location) is not physically reasonable.

\subsubsection{FEP Name: UNDETECTED DISCONTINUITIES}

Screening Criterion: Part of conceptual model

Disposition: Screened out from scenario development

Discussion: Undetected discontinuities are addressed through uncertainty in the conceptual model rather than scenario development. An evaluation of the disposal system should be made to determine whether undetected discontinuities need to be considered in the conceptual model.

\subsubsection{FEP Name: UNDETECTED GEOLOGICAL FEATURES}

Screening Criterion: Part of conceptual model

Disposition: Screened out from scenario development

Discussion: Undetected features are addressed through uncertainty in the conceptual model rather than scenario development. An evaluation of the disposal system should be made to determine whether undetected features need to be considered in the conceptual model. 


\subsubsection{FEP Name: VOLCANIC ACTIVITY}

Screening Criterion: Silicic--physical reasonableness Basaltic--physical reasonableness

Disposition: Silicic--screened out from scenario development Basaltic--screened out from scenario development

Discussion: Silicic volcanism--Silicious (tuffaceous) volcanic rocks and volcanic features from which these rocks originated occur extensively throughout the NTS region. The absence of silicic volcanism in the NTS region over the past 6 million years suggests that the conditions that caused silicic eruptions in the region are no longer active. In the absence of seismic activity that associated with movements within a magma body at depth that could be a source for this type of volcanic activity and an absence of anomalously high heat flow associated with such a body, changes in the geologic processes within the next 10,000 years that would result in silicic eruptions in the NTS region are not physically reasonable.

Basaltic volcanism--Basaltic volcanic features such as cinder cones and feeder dikes are present in the NTS region. Although cinder cones are not present within Frenchman Flat, lava flows have been reported within the basin-fill deposits in the northern part of Frenchman Flat (Carr et al., 1975). Within the Flat itself, the lack of reported evidence of feeder dikes to these lava flows suggests that these lava flows originated outside of Frenchman Flat (Carr et al., 1975). Recently obtained age dates from a basalt flow in Frenchman Flat indicate an age of approximately 8.6 million years (Rawlinson, 1993). The evidence indicates (1) that no feeder dikes have been emplaced within the Frenchman Flat basin-fill sediments younger than the dated basalt flow (Rawlinson, 1993) and (2) that no basaltic volcanism has occurred in the immediate vicinity of or within Frenchman Flat for approximately 8.6 million years. These lines of evidence suggest that the geologic conditions at Frenchman Flat are not suitable for basaltic volcanic activity. In light of this geologic stability with regard to volcanic activity, changes in the regional or local geologic processes within the next 10,000 years that would result in basaltic dikes being emplaced or basaltic lava flows being extruded at or near the GCD facility are not physically reasonable.

A discussion of volcanism in the Frenchman Flat region is included in this report as Appendix F. 


\title{
1.2 HYDROLOGIC FEPs
}

\subsubsection{FEP Name: ADVECTION AND DISPERSION}

\author{
Screening Criterion: Base-case conditions
}

Disposition: Part of base-case scenario

Discussion: Both advection and dispersion will occur within the time frame of regulatory concern. As a result, both processes are part of the base-case conditions. Both of these processes need to be evaluated to determine their significance to the performance of the disposal system.

\subsubsection{FEP Name: ALTERATION OF HYDROLOGIC CONDITIONS}

Screening Criterion: Response of disposal system

Disposition: Screened out from scenario development

Discussion: Changes in the hydrologic conditions are responses to other changes in the disposal system.

\subsubsection{FEP Name: CHANGES IN RIVER REGIME, LAKE LEVELS}

Screening Criterion: River--Applicability to geologic setting Lake--Applicability to geologic setting

Disposition: River--Screened out from scenario development Lake--Screened out from scenario development

Discussion: River--No perennial streams or rivers exist within or near the location of the disposal system. No evidence collected to date indicates that perennial streams or rivers are likely to occur in the area under a repeat of past or expected future climatic conditions.

Lake--Investigations that included the determination of whether a perennial lake existed within Frenchman Flat during the last glacial maximum (Lahontan Time) have produced contradictory results. Mifflin and Wheat (1979) primarily used air photographs, topographic maps, and elevation-control data to locate and map shoreline features as evidence of late Quaternary pluvial lakes in topographic basins throughout the state of Nevada. Field reconnaissance was used to supplement their findings for some locations. No shoreline features were found within Frenchman Flat, which led to the conclusion that no pluvial lake of late 
Quaternary age had existed within this basin. No field checks were made to confirm this conclusion.

Craig et al. (1984) used long-range climatic models to estimate which basins in the NTS region contained pluvial lakes. Modeling results were based on predictions of temperature, evapotranspiration, precipitation, and runoff. The modeling indicated that Frenchman Flat did contain a pluvial lake, and this lake also received overflow from a lake in Yucca Flat. No field work was performed to locate geologic evidence to support either of these conclusions.

Profiles of chlorine concentration as a function of depth at several locations on the north side of Frenchman Flat suggest that recharge has been at most negligible for hundreds of thousands of years (Conrad, 1993). The presence of a lake of the extent estimated by Craig et al. (1984) should have been accompanied by high enough recharge to destroy the chlorine profiles currently present in the soils.

The combination of absence of shoreline features surrounding Frenchman Flat and the presence of relatively shallow anomalous chlorine concentrations suggest that a perennial pluvial lake did not exist in Frenchman Flat. For this reason, changes in lake level are not considered in scenario development.

\subsubsection{FEP Name: EFFECTS OF SALINE-FRESHWATER INTERFACE}

Screening Criterion: "Process" not adequately defined

Disposition: Screened out from scenario development

Discussion: No explanation is provided in the original reference for this process as to what this process is or why this process should be considered in scenario development. In a site-specific application to the NTS, no sources of "saline" water have been identified.

\subsubsection{FEP Name: FLOODING OF SITE}

Screening Criterion: Base-case condition

Disposition: Part of base-case scenario

Discussion: On an alluvial fan, flooding is a short-term phenomenon resulting from storms. Short-term, storm-related flooding lasting hours does not affect the long-term performance of a disposal system. 


\subsubsection{FEP Name: FLUIDS CARRY WASTE TO RIVERS OR TRIBUTARIES}

Screening Criterion: Response of disposal system

Disposition: Screened out from scenario development

Discussion: The path for radionuclide transport to the accessible environment is the result of modeling the disposal system and not part of scenario development.

\subsubsection{FEP Name: FLUIDS CARRY WASTE TO WELLS OR SPRINGS}

Screening Criterion: Response of disposal system

Disposition: Screened out from scenario development

Discussion: The path for radionuclide transport to the accessible environment is the result of modeling the disposal system and not part of scenario development.

\subsubsection{FEP Name: FLUIDS LEAVE ALONG NEW FAULTS}

Screening Criterion: Response of disposal system

Disposition: Screened out from scenario development

Discussion: The pathways for radionuclide transport to the accessible environment are determined by developing conceptual models of the disposal system and are not part of scenario development.

\subsubsection{FEP Name: FLUX THROUGH REPOSITORY}

Screening Criterion: Response of disposal system

Disposition: Screened out from scenario development

Discussion: Whether or not any ground-water flow occurs through the repository is the result of modeling the disposal system and not part of scenario development.

\subsubsection{FEP Name: GAS MEDIATED TRANSPORT}

Screening Criterion: Part of conceptual model

Disposition: Screened out from scenario development 
Discussion: Corrosion of metals and decomposition of organic materials in the waste and waste containers are likely to be sources of gas. Gas mediated transport needs to be evaluated to determine if this capability should be included in the conceptual model of the disposal system.

\subsubsection{FEP Name: GEOTHERMALLY-INDUCED FLOW}

Screening Criterion: Base-case condition

Disposition: Screened out from scenario development

Discussion: Based on information derived from Muffler (1979), the southwestern and south-central portions of the NTS are classified as within an area favorable for discovery and development of local sources of low-temperature geothermal resources. The GCD area was not identified as having a potential for the production of geothermal energy. With no anomalous heat flow in the GCD area, any contribution of geothermal heat flow to ground-water movement in either the saturated or unsaturated zone relatively uniform across this area. The contribution to heat flow is likely to be on such a small scale as to have no effect on groundwater flow.

Several million years have passed since the last episode of acidic volcanism in the region, and no evidence of basaltic volcanism originating within Frenchman Flat has been cited in the literature. Major changes in the tectonic regime are not likely to occur within the next 10,000 years, so the development of major changes to the present geothermal regime within this time frame also is not likely to occur.

\subsubsection{FEP Name: GROUND-WATER CONDITION (SATURATED, UNSATURATED)}

Screening Criterion: Part of conceptual model

Disposition: Screened out from scenario development

Discussion: The hydrologic state of the geologic units of the disposal system are part of the basic conditions that establish the conceptual model.

\subsubsection{FEP Name: GROUND-WATER DISCHARGE TO SURFACE WATER}

Screening Criterion: Response of disposal system

Disposition: Screened out from scenario development 
Discussion: The pathway for ground-water discharge to the surface is determined by modeling the disposal system and is not part or scenario development.

\subsubsection{FEP Name: GROUND-WATER FLOW (DARCY, NONDARCY, INTERGRANULATED FRACTURING)}

Screening Criterion: Part of conceptual model

Disposition: Screened out from scenario development

Discussion: The assumptions about how water flows within the disposal system is part of the conceptual model.

\subsubsection{FEP Name: GROUND-WATER FLOW PATHS ARE SHORTENED}

Screening Criterion: Response of disposal system

Disposition: Screened out from scenario development

Discussion: The path length for ground-water flow is determined by modeling flow of the disposal system.

\subsubsection{FEP Name: GROUND-WATER RECHARGE}

\section{Screening Criterion: Parameter name}

Disposition: Screened out from scenario development

Discussion: Parameter names indicate possible input requirements to the modeling of the disposal system and are not events or processes included in scenario development.

\subsubsection{FEP Name: HEAD IS ABOVE OUTFALL}

Screening Criterion: Part of conceptual model

Disposition: Screened out from scenario development

Discussion: The hydrologic conditions of the disposal system are part of the conceptual model. 


\subsubsection{FEP Name: HEAD IS BELOW OUTFALL}

Screening Criterion: Part of conceptual model

Disposition: Screened out from scenario development

Discussion: The hydrologic conditions of the disposal system are part of the conceptual model.

\subsubsection{FEP Name: INFILTRATION AND EVAPOTRANSPIRATION}

Screening Criterion: Base-case conditions

Disposition: Part of base-case scenario

Discussion: Both infiltration and evaporation are certain to occur at the GCD location and therefore are part of base-case conditions.

\subsubsection{FEP Name: MIGRATION OF BRINE AQUIFER}

Screening Criterion: Response of disposal system

Disposition: Screened out from scenario development

Discussion: If a brine aquifer (a hydrologic unit with the capacity to produce relatively high volumes of nonpotable, saline water) exists within or near the GCD disposal system, changes in the location of such an aquifer are determined through modeling of the system and are not predetermined in sienario development.

\subsubsection{FEP Name: MULTIPHASE FLOW AND GAS-DRIVEN FLOW}

Screening Criterion: Part of conceptual model

Disposition: Screened out from scenario development

Discussion: The assumptions of how fluids move within the disposal system are capabilities included in the conceptual model of the system.

\subsubsection{FEP Name: STRESS CHANGES OF CONDUCTIVITY}

Screening Criterion: "Process" not adequately defined

Disposition: Screened out from scenario development 
Discussion: The process is not adequately defined in the original reference.

\subsubsection{FEP Name: THERMAL EFFECTS ON GROUND-WATER FLOW}

Screening Criterion: Response of disposal system

Disposition: Screened out from scenario development

Discussion: The ability to determine the effects of temperature on ground-water flow should be based on a capability incorporated in the conceptual model of the disposal system.

\subsubsection{FEP Name: TRANSPORT OF RADIONUCLIDES}

Screening Criterion: Response of disposal system

Disposition: Screened out from scenario development

Discussion: Transport of radionuclides by whatever processes is a capability incorporated in the conceptual model of the disposal system. 


\subsection{GEOCHEMICAL FEPS}

\subsubsection{FEP Name: ACCUMULATION IN SOILS AND ORGANIC DEBRIS}

Screening Criterion: Part of conceptual model

Disposition: Screened out from scenario development

Discussion: Soils are present within the basin-fill deposits at the GCD location. The capability to determine interactions of soils and radionuclides is part of the conceptual model and not part of scenario development.

\subsubsection{FEP Name: CHEMICAL EQUILIBRIUM REACTIONS}

Screening Criterion: Base-case condition

Disposition: Part of base-case scenario

Discussion: Chemical-equilibrium reactions will occur within the disposal system, although the locations within the system will depend on the radionuclide migration paths.

\subsubsection{FEP Name: CHEMICAL GRADIENTS (ELECTROCHEMICAL EFFECTS AND OSMOSIS)}

Screening Criterion: Base-case condition

Disposition: Part of base-case scenario

Discussion: Chemical gradients will occur within the disposal system, and as a result, these gradients are a base-case condition.

\subsubsection{FEP Name: COLLOID DISSOLUTION}

Screening Criterion: Part of conceptual model

Disposition: Screened out from scenario development

Discussion: With the formation of colloids, the capability to model the processes that affect colloids is part of the geochemistry conceptual model that incorporates the steps from colloid formation through transportation. 


\subsubsection{FEP Name: COLLOID FORMATION}

Screening Criterion: Part of conceptual model

Disposition: Screened out from scenario development

Discussion: With the formation of colloids, the capability to model the processes that affect colloids is part of the geochemistry conceptual model that incorporates the steps from colloid formation through transportation.

\subsubsection{FEP Name: COLLOID TRANSPORT}

Screening Criterion: Part of conceptual model

Disposition: Screened out from scenario development

Discussion: With the formation of colloids, the capability to model the processes that affect colloids is part of the geochemistry conceptual model that incorporates the steps from colloid formation through colloid transportation.

\subsubsection{FEP Name: COMPLEXING AGENTS}

Screening Criterion: Part of conceptual model

Disposition: Screened out from scenario development

Discussion: If complexing agents will be present in the disposal system, their effects of the geochemistry should be incorporated into the conceptual model of the postclosure disposal system.

\subsubsection{FEP Name: CRYSTALLIZATION}

Screening Criterion: "Process" not adequately defined

Disposition: Screened out from scenario development

Discussion: Explanation in original reference is not adequate to determine how extensively or narrowly this definition is to be applied.

\subsubsection{FEP Name: DIAGENESIS}

Screening Criterion: Base-case condition 
Disposition: Part of base-case scenario

Discussion: Diagenesis refers to the subsurface chemical, physical, and biological changes that occur in a sediment after the initial deposition and subsequent lithification, excluding surficial alteration (Bates and Jackson, 1987, p. 180). The basin-fill deposits within Frenchman Flat are undergoing diagenetic changes. Because these changes are ongoing and certain to during the time frame of regulatory concern, this FEP is part of the base-case scenario.

\subsubsection{FEP Name: DISSOLUTION OTHER THAN LEACHING}

Screening Criterion: Part of conceptual model

Disposition: Screened out from scenario development

Discussion: Dissolution of any type is a capability that should be included in the conceptual model of the disposal system.

\subsubsection{FEP Name: FRACTURE MINERALIZATION AND WEATHERING}

Screening Criterion: Applicability to geologic setting/Part of conceptual model

Disposition: Screened out from scenario development

Discussion: Fractures have not been reported in the basin-fill and alluvial-fan deposits in the vicinity of GCD. Fractures are likely to exist in at least some of the volcanic units beneath the sediments. If the deeper units are important to the PA of this location, mineralization or weathering along these fractures that is different from any mineralization or weathering that is currently occurring should be addressed through modeling rather than scenario development.

\subsubsection{FEP Name: GEOCHEMICAL CHANGES FROM NATURAL CAUSES}

Screening Criterion: Base-case condition

Disposition: Part of base-case scenario

Discussion: Changes in the disposal system that occur during undisturbed conditions are part of the base-case scenario.

\subsubsection{FEP Name: MASS, ISOTOPIC, AND SPECIES DILUTION}

Screening Criterion: Response of disposal system 
Disposition: Screened out trom scenario development

Discussion: Dilution of any type should be addressed through the capabilities of the conceptual model to respond to changes in the disposal system. Such changes are not addressed through scenario development.

\subsubsection{FEP Name: MATRIX DIFFUSION}

Screening Criterion: Applicability to geologic setting

Disposition: Screened out from scenario development

Discussion: In modeling for performance assessments, matrix diffusion refers to the diffusion of dissolved radionuclides from the water within fractures into the interstitial water within the rock matrix adjacent to the fracture. For the unsaturated alluvial sediments at the GCD location, fracture flow does not occur, so matrix diffusion is not a process that can occur.

\subsubsection{FEP Name: NATURAL ELECTROCHEMICAL REACTIONS}

Screening Criterion: FEP not adequately defined

Disposition: Screened out from scenario development

Discussion: Prij et al. (1991, see FEP 3.2.3) attribute natural telluric electrochemical reaction to the presence of tellurium in the disposal medium. This definition could not be confirmed in any other reference.

\subsubsection{FEP Name: PHYSICO-CHEMICAL CHARACTERISTICS INFLUENCING CHEMICAL EQUILIBRIUM}

Screening Criterion: Part of conceptual model

Disposition: Screened out from scenario development

Discussion: The basic characteristics of the disposal system that affect chemical equilibrium are part of the conceptual model of the system and are not events or processes that are used to develop scenarios.

\subsubsection{FEP Name: WEATHERING OF FLOW PATHS}

Screening Criterion: Process not adequately defined 
Dispositior: Screened out from scenario development

Discussion: Weathering is a surface or near-surface process. The term weathering does not apply to chemical alteration of the geologic materials in the disposal system at depth, especially in the saturated zone. 


\subsection{CLIMATIC FEPS}

\subsubsection{FEP Name: CHANGES IN GROUND-WATER [FLOW]}

Screening Criterion: Response of disposal system

Disposition: Screened out from scenario development

Discussion: Changes in ground-water flow that occur because of climatic change are determined through the modeling of the disposal system.

\subsubsection{FEP Name: CLIMATIC CHANGE}

Screening Criterion: Base-case condition

Disposition: Part of base case

Discussion: Based on evidence of past climatic change in the NTS region (see Mifflin and Wheat, 1979), the probability of some level of climatic change at the GCD during the next 10,000 years is 1 . Because $P=1$, climatic change is part of the base-case conditions. The specific extent of climatic changes and the effects of these changes on the integrity and performance of the disposal system must be determined.

\subsubsection{FEP Name: COASTAL SURGE, STORMS}

Screening Criterion: Physical reasonableness

Disposition: Screened out from scenario development

Discussion: GCD is located more than 275 miles (442 kilometers) from the nearest ocean. Changes in geography within the next 10,000 years to an extent that coastal processes would affect the GCD location is not physically reasonable.

\subsubsection{FEP Name: HIGH SEASONALITY}

Screening Criterion: FEP not defined

Disposition: Screened out from scenario development

Discussion: This FEP was not adequately defined in the original reference. 


\subsubsection{FEP Name: HURRICANES}

Screening Criterion: Physical reasonableness

Disposition: Screened out from scenario development

Discussion: Hurricanes are storms that originate over warm ocean water in the tropics. These storms are characterized by high wind speeds and heavy rainfall, although the intensity of the storms tends to dissipate over cold water or land.

Hurricanes can be eliminated from performance assessments for the GCD location, because the survival of this type of storm is not physically reasonable as far inland as the GCD location. Intense storms are certain to occur at any disposal location, and for this reason, intense storms are part of normal climatic conditions.

\subsubsection{FEP Name: NO ICE AGE}

Screening Criterion: Part of conceptual model

Disposition: Screened out from scenario development

Discussion: Based on information available in the literature, the NTS region has not been subjected to either alpine or continental glaciation since at least the beginning of Paleozoic time. Changes in geologic and/or climatic conditions to an extent that glaciation would occur at this location within the next 10,000 years are not physically reasonable. As a result, No Ice Age is the expected climatic condition for the disposal system during the time period of regulatory concern.

\subsubsection{FEP Name: PERIGLACIAL EFFECTS}

Screening Criterion: Physical reasonableness

Disposition: Screened out from scenario development

Discussion: Periglacial effects are limited to areas in the immediate vicinity of the margins of glaciers (Bates and Jackson, 1987). No evidence has been cited for the NTS and vicinity to support the past presence of glaciers within this region. Changes in geologic and/or climatic conditions to an extent that glaciation would occur within this region during the next 10,000 years are not physically reasonable.

\subsubsection{FEP Name: PERMAFROST}

Screening Criterion: Physical reasonableness 
Disposition: Screened out from scenario development

Discussion: Permafrost, which is permanently frozen ground, results from temperatures that remain too cold throughout the year for thawing to occur. No evidence has been noted in paleoclimatic studies in the NTS region that indicate yearly temperature cycles that would result in the formation or maintenance of permafrost. Changes in climatic conditions within the time period of regulatory concern that would result in the formation of permafrost at the GCD location are not physically reasonable.

\subsubsection{FEP Name: PRECIPITATION, TEMPERATURE, SOIL-WATER BALANCE}

\section{Screening Criterion: Parameter names}

Disposition: Screened out from scenario development

Discussion: Parameter names indicate possible input requirements to models of the disposal system and are not events or processes used for scenario development.

\subsubsection{FEP Name: TORNADOS}

\section{Screening Criterion: Consequence}

Disposition: Screened out from scenario development

Discussion: The effects of tornados are restricted to the surface environment. No effects of tornados on the performance of a disposal system for buried waste have been identified. With no effects on the subsurface environment, tornados can be considered to have no consequence on the disposal system after closure of the disposal facility. 


\subsection{ECOLOGICAL FEPS}

\subsubsection{FEP Name: ANIMAL INTAKE}

\section{Screening Criterion: Regulatory restrictions on PA}

Disposition: Screened out from scenario development

Discussion: This process refers to animal ingestion of contaminated plants and water at the surface as part of the biological pathway for radionuclides to reach humans. Biological pathways are not needed to address the Containment Requirements.

\subsubsection{FEP Name: BIOTURBATION OF SOIL SEDIMENTS}

Screening Criterion: Base-case condition

Disposition: Part of base-case scenario

Discussion: The Containment Requirements are based on cumulative radionuclide releases to the accessible environment without specifying how the radionuclides reach the accessible environment. Bioturbation is the process of churning and stirring of a sediment by organisms (Bates and Jackson, 1987). This process will occur at the GCD location as a result of burrowing by ants, termites, other insects, and possibly by certain mammals and reptiles. Whether radionuclides are brought to the surface by this burrowing will depend on the migration paths of radionuclides relative to such activity.

\subsubsection{FEP Name: CHEMICAL TRANSFORMATIONS}

Screening Criterion: Regulatory restrictions on PA

\section{Disposition: Screened out from scenario development}

Discussion: These processes refer to changes in the biosphere transfer factors and radionuclide-retardation factors caused by changes to different states of a chemical (e.g., oxide vs sulfide) (Prij et al., 1991). The Containment Requirements are based on cumulative radionuclide releases to the accessible environment. What happens to the radionuclides after reaching the accessible environment is not relevant to addressing these requirements. 


\subsubsection{FEP Name: ECOLOGICAL RESPONSE TO CLIMATIC CHANGE}

Screening Criterion: Base-case condition

Disposition: Part of base-case scenario

Discussion: Climatic change is certain to occur during the next 10,000 years, and as a result, ecological changes also will occur. Whatever effects changes in the plant community has on the water budget should be considered when establishing basecase conditions.

\subsubsection{FEP Name: EVOLUTION}

Screening Criterion: Base-case condition

Disposition: Part of base-case scenario

Discussion: Evolution of some plant and animal species will occur during the period of regulatory concern. Although the resultant changes could affect bioturbation, evapotranspiration, and plant uptake of radionuclides, the extent of these effects are likely to be overwhelmed by the ecological changes in response to climatic changes during this same time interval.

\subsubsection{FEP Name: MICROBIAL INTERACTIONS}

Screening Criterion: Base-case condition

Disposition: Part of base-case scenario

Discussion: Microbes are present in the natural environment and in the GCD waste, and as a result are included in base-case conditions.

\subsubsection{Name: PLANT UPTAKE}

Screening Criterion: Base-case condition

Disposition: Part of base-case scenario

Discussion: Plants will repopulate the GCD location over time, and their roots will extend to some depth and take up moisture. Whether the plants will provide pathways for radionuclides to reach the surface depends on the uptake capability of the various species of plants, root depth, and the migration paths and mechanisms for the various radionuclides. 


\subsection{EXTRATERRESTRIAL FEPS}

\subsubsection{FEP Name: DETERMINATION OF IMPACT FREQUENCIES}

Screening Criterion: Parameter name

Disposition: Screened out from scenario development

Discussion: Impact frequency is a parameter that can be used to calculate the probability of meteor impact at a particular location. Parameter names are not used to develop scenarios.

\subsubsection{FEP Name: IMPACT FRACTURING}

Screening Criterion: Probability of occurrence

Disposition: Screened out from scenario development

Discussion: See discussion on Meteorite Impact

\subsubsection{FEP Name: METEORITE IMPACT}

Screening Criterion: Probability of occurrence

Disposition: Screened out from scenario development

Discussion: Several estimates have been made of the probability of a meteorite impact large enough to significantly disrupt the performance of a deep nuclearwaste disposal facility. These estimates range from approximately $1 \times 10^{-13} / \mathrm{yr}$ to 1 $x 10^{-12} / \mathrm{yr}$ depending on the assumptions of repository size, depth of disruption, and impact frequency (Claiborne and Gera, 1974; Kärnbränslesakerhert 1978; Logan and Berbano, 1978; Hartmann, 1979; Cranwell et al., 1990). Each of the estimates is substantially below the lower limit of 1 chance in 10,000 in 10,000 years established in the Standard for those events and processes that need to be included in performance assessments.

\subsubsection{FEP Name: PROBABILITY OF DAMAGE}

Screening Criterion: Probability of occurrence

Disposition: Screened out from scenario development

Discussion: See Discussion for Meteorite Impact. 


\subsubsection{FEP Name: SOLAR INSOLATION}

Screening Criterion: Base-case condition

Disposition: Part of base case

Discussion: The probability of the incidence of sunlight on Earth during the next 10,000 years is 1 . This probability of occurrence makes this process part of the base case, although the effects of variation in solar insolation on vegetation and the subsequent impact on evapotranspiration is considered under the topic heading of climatic change. 


\subsection{HUMAN-INDUCED PHENOMENA}

\subsection{OPERATION AND CLOSURE FEPS}

\subsubsection{FEP Name: ABANDONMENT OF POORLY SEALED OR UNSEALED REPOSITORY}

Screening Criterion: Part of conceptual model

Disposition: Screened out from scenario development

Discussion: Closure of the boreholes at the GCD after the waste has been emplaced consists of refilling the remainder of the borehole with material that had been removed during drilling. Specially designed seals have not been used for the boreholes at the GCD. The properties of the backfill material are part of the conceptual model of the disposal system.

\subsubsection{FEP Name: ACCIDENTS DURING OPERATION}

Screening Criterion: Regulatory restrictions

Disposition: Screened out from scenario development

Discussion: Performance assessments to address the Containment Requirements are based on the postclosure performance of the disposal system.

\subsubsection{FEP Name: COSTORAGE OF OTHER WASTES}

Screening Criterion: Part of conceptual model

Disposition: Screened out from scenario development

Discussion: The type of waste or combination of wastes stored in the GCD boreholes is the basis for the conceptual model of the source term used in modeling the performance of the disposal system.

\subsubsection{FEP Name: PHASED OPERATION EFFECTS}

Screening Criterion: Regulatory restrictions

Disposition: Screened out from scenario development 
Discussion: Performance assessments to address the Containment Requirements are based on postclosure performance. Postclosure begins when GCD operations cease. Any effects of the operations on the disposal system should be included in the conceptual model used for performance assessments. 


\title{
2.2 POSTCLOSURE SURFACE ACTIVITIES
}

\subsubsection{FEP Name: ANTHROPOGENIC CLIMATIC CHANGES}

\author{
Screening Criterion: Consequence
}

\section{Disposition: Screened out from scenario development}

Discussion: Much of the current attention on anthropogenic climatic changes is focused on the possible effects of increasing concentrations of $\mathrm{CO}_{2}$ and other gases in the atmosphere resulting in global warming with the associated effects on rainfall patterns, growing seasons, and ocean temperatures. Changes on a more local scale also may result from activities such as urbanization and irrigation.

The topic of global climate change as a result of human activity is controversial both in the areas of whether past change has occurred and whether future change is likely to occur. Both of these areas lack a consensus among climatologists. Interpretations and predictions of human-induced climate change are hampered by ambiguous data on past climate change, limited understanding of the dynamics in the global-climatic system, computing capabilities inadequate for the level of modeling detail required to simulate the natural system, and inadequate data for simulating the current climate and long-term climatic changes from both naturally occurring and human-induced effects. Additional complications are added when trying to use global models to predict site-specific climatic changes.

Because of the preliminary nature of computer modeling of climate change, an alternative approach to estimate anthropogenic climatic change is to use a panel of experts. The WIPP Program assembled a panel of experts whose backgrounds covered a broad range of technical fields to identify possible future states of society and modes of human intrusion into the WIPP disposal facility in southeastern New Mexico for inclusion in performance assessments. None of the four teams of experts, which together composed the panel, identified global climatic changes from human activity as being a serious long-term concern to disposal-system performance (Hora et al., 1991). One of the four teams identified near run-away greenhouse effect as a low to very-low probability event and deliberate local weather modification as a mode of human activity that could conceivably affect a disposal system. One drawback to using the conclusions on climate change of this panel for the GCD location is that only one of the 16 experts was identified as a specialist in agriculture/climatology. A panel of climatologists might reach different conclusions.

When viewed as a whole, the modeling efforts to date on climatic change resulting from human activities are inconclusive. The conclusions of the WIPP Program's 
panel of experts is of questionable site-specific value because of the substantial difference in climatic settings between the WIPP and GCD locations. For the purpose of scenario development, a neutral position is taken as to whether anthropogenic climatic change improves or degrades disposal-system performance for this iteration of FEP screening. Anthropogenic climatic change is assumed to be of no consequence to GCD disposal-system performance when compared to or combined with naturally occurring climatic change. This FEP will be rescreened over the course of the next year, and scenario construction will be revised if warranted.

\subsubsection{FEP Name: CHANGES IN LAND USE}

Screening Criterion: Regulatory restrictions

Disposition: Screened out from scenario development

Discussion: Based on the original definition of this FEP (Prij et al., 1991), the purpose of this FEP is to incorporate changes in surface activities into healtheffects calculations. Estimation of cumulative releases to the accessible environment are necessary to determine compliance with the Containment Requirements. The health effects caused by radionuclides that reach the accessible environment are not relevant to these requirements. Mining of surficial deposits is discussed under FEP 2.2.9 Quarrying, Near Surface.

\subsubsection{FEP Name: CHEMICAL SABOTAGE}

Screening Criterion: Regulatory restrictions

Disposition: Screened out from scenario development

Discussion: Appendix B of the Standard indicates that inadvertent human intrusion is the only type of human intrusion that needs to be included in performance assessments. Sabotage either to cause or enhance radionuclide releases is advertent and does not need to be included in scenario development for performance assessments.

\subsubsection{FEP Name: CONSTRUCTION OF DAMS/RESERVOIRS}

Screening Criterion: Physical reasonableness

Disposition: Screened out from scenario development 
Discussion: No perennial streams or rivers exist within Frenchman Flat, so the construction of dams for the impoundment of water is not feasible. The topographic relief on the alluvial fan at and near the GCD location is too low for dams in ephemeral stream channels to be constructed to deliberately increase recharge. No physical evidence has been reported to support the existence of a perennial lake in Frenchman Flat during wetter past climatic conditions (Mifflin and Wheat, 1979). Future climates are likely to mimic past climates, so future climatic changes are unlikely to provided sufficient moisture to maintain a reservoir. Although ground water is available within Frenchman Flat, the depth and quantity are unlikely to be sufficient to create and maintain a reservoir. Changes in the topography, climate, and water supply to an extent that dams or a reservoir within Frenchman Flat would be feasible are not physically reasonable within the time frame of regulatory concern.

\subsubsection{FEP Name: EXPLOSIONS}

\section{Screening Criterion: Consequence}

\section{Disposition: Screened out from scenario development}

Discussion: Surface explosions, either nuclear or nonnuclear, at the GCD location that result in cratering that exhumes waste or radionuclides that have migrated from the waste would be a more severe type of human intrusion than required for consideration by the Standard. Explosions away from the site would generate a shock wave at the surface that would quickly attenuate at depth. The likelihood of a return to surface testing of nuclear devices is remote because of the increase in worldwide environmental awareness. Surface testing of nonnuclear explosives is possible, although the magnitudes of these explosions are substantially less than nuclear tests. If these types of explosions occur, the effect on the performance of the disposal system would range from minor to none.

\subsubsection{FEP Name: FISHERIES DEVELOPMENT}

Screening Criterion: Regulatory restrictions/Physical reasonableness

\section{Disposition: Screened out from scenario development}

Discussion: Fisheries development was originally considered for scenario development in connection with health effects. This FEP can be eliminated from consideration in scenario development in this context, because health effects are not relevant to determining compliance with the Containment Requirements. In the context of disposal-system performance, man-made fisheries on a scale that could affect performance are not physically reasonable. Any attempt at 
constructing fisheries on the piedmont slopes of Frenchman Flat would require the digging of relatively small and relatively shallow depression (perhaps a couple of meters deep). The depressions themselves would be too shallow to affect performance of the disposal system. Because of the permeability of the sands and gravels that compose the basin-fill deposits and with ground water at a depth of hundreds of meters as the only reliable source of water, the depressions would have to be lined to minimize water loss through infiltration. If fisheries development could be economically feasible, the presence of LLW in trenches near the GCD boreholes make the selection of the RWMS for fisheries development physically unreasonable considering the vast areas within Frenchman Flat that would be more suitable.

\subsubsection{FEP Name: IRRIGATION}

\section{Screening Criterion: None}

\section{Disposition: Retained for scenario development}

Discussion: Irrigation is an activity that potentially can affect disposal-system performance. Irrigation may affect the amount and depth of infiltration, and crop roots may affect the transportation of radionuclides to the accessible environment (i.e., the surface). Although the water-resource potential for Frenchman Flat has not been determined at this time, preliminary information suggests that both quality (Gustafson et al., 1993a) and quantity of ground water may be suitable for irrigation purposes. Agricultural irrigation in Frenchman Flat was not considered to be practical by Richard-Haggard (1983) and Case et al. (1984) because of unfavorable soil properties and state restrictions on water use. An additional factor for the feasibility of irrigation is the expense caused by the depth from which ground water would have to be pumped. Based on the preliminary information on water quality and availability and the fact that portions of other basins in Nevada are used for farming, irrigation is retained for scenario development.

Low-level waste has been and is being disposed of within wooden boxes and both steel drums and boxes in relatively shallow trenches close to the GCD boreholes. As these boxes and drums decay, compaction of the waste will occur accompanied by subsidence of the overburden. Caps that will cover the trenches and boreholes will be constructed to accommodate predicted subsidence and still conform to regulatory design requirements. The possible effects of the presence of wastedisposal trenches, associated subsidence, and presence of a protective cap over the trenches and boreholes on possible future farming and irrigation have not been investigated at this time. Over the time frame of regulatory concern, subsidence and farming are not mutually exclusive. 


\subsubsection{FEP Name: LOSS OF RECORDS}

\section{Screening Criterion: Regulatory restrictions}

Disposition: Screened out from scenario development

Discussion: Records (archives) are passive institutional controls. The existence of records affect the probability of human intrusion but is not part of scenario development.

\subsubsection{FEP Name: QUARRYING, NEAR SURFACE}

Screening Criterion: Probability of occurrence

Disposition: Screened out from scenario development

Discussion: In the context of FEP screening, quarrying is assumed to be the same as strip mining. No shallow resources were identified at or near the GCD location (Richard-Haggard, 1983). The only materials in the GCD area of potential economic value that could be recovered through strip mining are sand and gravel. Although the quantities of sand and gravel may be adequate for resource use, the quality of the materials, especially the gravel because of the high pyroclasticvolcanic content (S.nyder et al., 1993), tends to be of limited usefulness (Gustafson et al., 1993a). The sedimentary materials at this location are not unique. The materials identified in trenches and pits are representative of deeper materials (Gustafson et al., 1993b). Similar materials are likely to be present throughout the alluvial fans within Frenchman Flat and other alluvial fans in the region. The wide-spread availability of the material at minable depth at the GCD location along with the low value of the resource potential of this material results in quarrying at or near the GCD location having an extremely low probability of occurring.

\subsubsection{FEP Name: RECHANNELING OF RIVERS}

Screening Criterion: Physical reasonableness

Disposition: Screened out from scenario development

Discussion: No perennial rivers exist in Frenchman Flat. The lack of physical features that would indicate the existence of a perennial body of water in Frenchman Flat under pluvial conditions (Mifflin and Wheat, 1979) suggests that no perennial streams or rivers existed under wetter climatic conditions to maintain such a body of water. A change in climatic, geographic, and geomorphic conditions 
to an extent that a river would exist in this basin within the next 10,000 years, and thereby be available for rechanneling, is not physically reasonable. 


\subsection{POSTCLOSURE SUBSURFACE ACTIVITIES}

\subsubsection{FEP Name: ALTERED SURFACE-WATER CHEMISTRY BY HUMANS}

Screening Criterion: Applicability to geologic setting

Disposition: Screened out from scenario development

Discussion: This FEP is based on the possibility of acidic rainfall caused by industry contaminating ground water that eventually reaches the waste. With no standing water currently or projected to occur at the GCD location, acidic water could only alter the chemistry at the waste if infiltration occurs to the depth of the waste and is not buffered by the sediments through which the water must pass. The question or whether infiltration reaches the waste under current climatic conditions or will reach the waste under projected climatic conditions has not been resolved, although work on environmental isotopes by Conrad (1993) suggests that infiltration has not penetrated very deeply into the alluvial deposits over a long time period. This issue of altered water chemistry may be irrelevant, because the relatively abundant carbonate in the basin-fill deposits above the waste would act as a buffer, thereby countering the acidification of the infiltrating water, which is the basis for this FEP.

\subsubsection{FEP Name: ARCHAEOLOGICAL EXHUMATION}

Screening Criterion: Regulatory restrictions

\section{Disposition: Screened out from scenario development}

Discussion: Appendix B of the Standard gives guidance on how to address inadvertent human intrusion into the disposal facility. The EPA considers inadvertent intrusion to be the only type of human intrusion that can be mitigated by repository design, site selection, or passive controls. In other words, no costeffective design, site selection, or passive controls can totally prevent advertent human intrusion, so including advertent intrusions in performance assessments is not productive.

The Summary of the Standard also states:

"...the Agency [EPA] believes it is important that the assumptions used by the implementing agencies are compatible with those used by EPA in developing this rule. Otherwise, implementation of the disposal standards may have effects quite different than those anticipated by EPA. (U.S. EPA, 1985, p. 38074). 
In calculating population risks as background in developing the Standard, Smith et al. (1982) considered exploratory drilling for resources as the only realistic mode of human intrusion into waste-storage facilities. To follow the intent of the EPA, advertent human intrusion is considered to be beyond the scope of performance assessments.

\subsubsection{FEP Name: ATTEMPT AT SITE IMPROVEMENT}

Screening Criterion: Regulatory restrictions

Disposition: Screened out from scenario development

Discussion: Attempts at improving the subsurface characteristics of the site would require an advertent intrusion. Advertent intrusions are outside the scope of performance assessments.

\subsubsection{FEP Name: CHANGE IN GROUND-WATER CHEMISTRY IN NEARBY ROCKS}

[SEDIMENTS]

Screening Criterion: Response of disposal system

Disposition: Screened out from scenario development

Discussion: Situations that could result in changes in ground-water chemistry in nearby sediments are part of the conceptual model. Changes in ground-water chemistry are a response of the disposal system to some type of external changes. For example, the low-level nuclear waste in shallow trenches near the GCD boreholes or the TRU waste in the GCD boreholes could change the water chemistry in response to the occurrence of other events or processes.

If changes in chemistry are going to occur because of the environment of the disposal facility, these changes should be part of the base-case scenario.

\subsubsection{FEP Name: DRILLING OF WITHDRAWAL WELLS/INJECTION WELLS}

\section{Screening Criterion: None}

\section{Disposition: Retained for scenario development}

Discussion: The presence of a Lower Carbonate, Tuff, and Valley Fill Aquifers within the stratigraphic section at Frenchman Flat (see Section 2.10) suggests that 
withdrawal wells may be drilled in the future to supply water for surface activities. Underpressured hydrologic units at depth, if such units exist, could be targeted for the injection of liquid wastes. Drilling either withdrawal or injection wells could provide a pathway from the waste to the accessible environment (i.e., the surface) if waste is intercepted and incorporated into the drilling fluid and brought to the surface. In this iteration of scenario development, the drilling of water and injection wells is retained as a separate FEP. The final version of scenario development may combine the drilling of these types of boreholes with exploratory drilling for resources.

If radionuclides reach the water table, withdrawal wells into the shallower groundwater units could provide pathways for contaminated water to reach the surface if the wells intercept the contaminant plume. Withdrawal wells also could change the ground-water flow gradient by creating a cone of depression around the wells. Recent work by Conrad (1993) suggests that recharge is unlikely to occur on the piedmont slopes at the GCD location on a scale that will affect disposal-system performance.

Injection wells probably would be deep and into underpressured units. If downward migration of radionuclides to the water table is unlikely to occur, as suggested by Conrad (1993), injected fluids at depth would have no impact on the performance of the disposal system.

\subsubsection{FEP Name: EARTHQUAKE FROM MAN-MADE CAUSES}

Screening Criterion: Consequence

\section{Disposition: Screened}

Discussion: In at least the short term, explosions associated with mining in the region (e.g., Bare Mountain to the west of NTS) and certain defense-related activities at the NTS will continue to cause minor earthquakes to be recorded (see Appendix E). The magnitude of these earthquakes is too low to have an effect on the performance of the disposal system. Containment of underground explosions requires limits to the actual size of the explosions. Such size restrictions and the resultant seismic effects are likely to be in place for as long as underground explosions are detonated.

\subsubsection{FEP Name: EXPLORATORY DRILLING FOR RESOURCES}

Screening Criterion: None

Disposition: Retained for scenario development 
Discussion: Future exploratory drilling is likely to have a probability of occurrence greater than the cut-off probability in the Standard. This activity also is physically reasonable and could have a significant consequence if a borehole penetrates the waste. In addition, the Standard requires that boreholes be included in the performance assessments. The Summary of the Standard states:

The Agency [EPA] believes that performance assessments should consider the possibilities of such intrusion [exploratory drilling for natural resources], but that limits should be placed on the severity of the assumptions used to make the assessments. Appendix B to the final rule describes a set of parameters about the likelihood and consequences of inadvertent intrusion that the Agency assumed were the most pessimistic that would be reasonable in making performance assessments. The implementing agencies may adopt these assumptions or develop similar ones of their own. (U.S. EPA, 1985, p. 38077).

In summary, performance assessments must include at least one borehole with a greater than 0 probability of occurrence (actually, greater than $10^{-4}$ ) during the period of regulatory concern $(10,000$ years $)$.

\subsubsection{FEP Name: GEOTHERMAL ENERGY PRODUCTION}

Screening Criterion: Physical reasonableness/Regulatory restrictions

Disposition: Screened out from scenario development

Discussion: Based on information derived from Muffler (1979), the southwestern and south-central portion of the NTS is classified as an area favorable for the discovery and development of local sources of low-temperature geothermal resources. The GCD area is not classified as having a potential for geothermal energy of any type. With the current information on the geologic setting and geothermal resources in the NTS region, changes in the geological conditions that would result in geothermal energy becoming viable resource at the GCD location are not physically reasonable.

In addition to not being physically reasonable for the geologic setting, geothermal energy production is beyond the scope of performance assessments to address the Containment Requirements. According to Appendix B of the Standard, exploratory drilling for resources is the most severe type of human intrusion that needs to be considered in performance assessments. Exploration for geothermal resources can be included with Future Boreholes discussed earlier in this section. 


\subsubsection{FEP Name: MALICIOUS INTRUSION, SABOTAGE/WAR}

Screening Criterion: Regulatory restrictions

Disposition: Screened out from scenario development

Discussion: Malicious intrusion and sabotage are advertent types of intrusion. The Standard limits performance assessments to including only inadvertent human intrusion.

Targeting of the GCD location in a war also would qualify as an advertent act. Given the location of the GCD facility and the lack of strategic targets in the immediate vicinity of Frenchman Flat, accidental strikes in a war would be low probability events.

\subsubsection{FEP Name: POSTCLOSURE MONITORING}

Screening Criterion: Part of base case

Disposition: Screened out from scenario development

Discussion: The plan for monitoring the performance of the disposal system should be developed and implementation of the plan should occur prior to closure of the disposal facility. Any instrumentation or features emplaced to monitor performance that could also affect performance should be part of the base-case conditions.

\subsubsection{FEP Name: RECOVERY OF REPOSITORY MATERIAL}

Screening Criterion: Regulatory restrictions

Disposition: Screened out from scenario development

Discussion: The Standard limits performance assessments to only including types of inadvertent human intrusion. Whereas the distinction between advertent and inadvertent intrusion is not always obvious, recovery of repository material requires a certain level of knowledge about what is at the site. Intruders with this knowledge who choose to intrude make such an event an advertent act.

The Standard also limits the severity of human-intrusion events. Inadvertent intrusion events more severe than exploratory drilling for natural resources do not have to be included in performance assessments. So even if recovery of repository 
material is judged to be inadvertent, this event can be eliminated from scenario development on the basis of severity restrictions specified in the Standard.

\subsubsection{FEP Name: RESOURCE MINING}

Screening Criterion: Probability of occurrence

Disposition: Screened out from scenario development

Discussion: No metallic minerals or industrial materials have been identified in the subsurface as having resource potential. The materials present in the subsurface at and near the GCD are common throughout Frenchman Flat and the region as a whole. This lack of resource potential and the widespread distribution of materials that have been identified as present make resource mining at any particular location a low probability event.

\subsubsection{FEP Name: REUSE OF BOREHOLES}

Screening Criterion: Consequence/Probability of occurrence

Disposition: Screened out from scenario development

Discussion: For waste buried in the unsaturated zone, the primary consequence of drilling into waste is the transport of some waste to the surface with circulating drilling fluid. If the borehole has been cased and the casing is intact, reuse of the borehole will have no consequence, because the drill bit and the circulating fluid do not again come in contact with the waste.

If the borehole has not been cased or the casing has degraded, collapse of the walls of the hole may occur or the hole will have debris blown in by the wind or washed in by rain. If the depth of the zone of collapse is at or close to the depth of the waste, some waste may be forced into the existing borehole. Because of the instability of such a borehole, reuse will be avoided by most drillers. The combination of a relatively low probability of occurrence for an exploratory borehole penetrating the waste and the low probability of the same borehole being reused leads to the conclusion that reuse of a borehole also can be eliminated from further consideration in performance assessments on the basis of low probability.

\subsubsection{FEP Name: STORAGE OF HYDROCARBONS, COMPRESSFD AIR, HOT WATER}

Screening Criterion: Applicability to geologic setting 
Disposition: Screened out from scenario development

Discussion: The basis for this FEP is that cavities can be formed underground for the storage of hydrocarbons, compressed air, or hot water. Constructed cavities in salt domes serve as storage structures. Because of the physical properties of the basin-fill and alluvial-fan deposits, storage cavities cannot be formed without major, and possibly prohibitive, reinforcement structures. The hydrologic properties of these materials will not permit the storage of liquids or gases without excessive leakage. Because of these limitations, the GCD area is not geologically suitable for underground storage facilities.

\subsubsection{FEP Name: SUBSIDENCE DUE TO GROUND-WATER WITHDRAWAL}

Screening Criterion: Consequence

Disposition: Screened out from scenario development

Discussion: No evidence for subsidence associated with the pumping of ground water at the NTS was cited in the general literature. Because subsidence is not uncommon in areas of extensive pumping, the potential for subsidence exists in Frenchman Flat if large-scale ground-water removal for irrigation or some other activity occurs.

Subsidence can cause cracking problems for buildings or other rigid structures. The GCD boreholes do not contain engineered seals that can structurally fail. The cap of earthen material that will cover the low-level waste trenches and probably the boreholes will be designed to accommodate subsidence resulting from compaction of the waste and the backfill without creating pathways for or locations of enhanced infiltration. Any subsidence from ground-water withdrawal is likely to be aerially more extensive than subsidence over individual or adjacent trenches. As a result, disruption of the overlying material on a broader scale will tend to be less severe than the disruption over the trenches. The cap over the trenches and boreholes should be able to accommodate subsidence of this type without creating pathways for enhanced infiltration. Subsidence that might occur as a result of ground-water removal in the vicinity of the RWMS will be of no consequence to disposal-system performance.

\subsubsection{FEP Name: TUNNELING}

Screening Criterion: Regulatory restrictions

Disposition: Screened out from scenario development 
Discussion: Appendix B of the Standard states

The Agency [EPA] believes that the most productive consideration of inadvertent intrusion concerns those realistic possibilities that may be usefully mitigated by repository design, site selection, or use of passive controls (although passive institutional controls should not be assumed to completely rule out the possibility of intrusion). Therefore, inadvertent and intermittent intrusion by exploratory drilling for resources (other than any provided by the disposal system itself) can be the most severe intrusion scenario assumed by the implementing agencies. (U.S. EPA, 1985, p. 38089).

Based on the severity of intrusion, tunneling can be eliminated from performance assessments.

\subsubsection{FEP Name: UNDERGROUND CONSTRUCTION}

Screening Criterion: Regulatory restrictions

Disposition: Screened out from scenario development

Discussion: Appendix B of the Standard states that exploratory drilling for resources is the most severe type of inadvertent human intrusion that needs to be included in performance assessments. Based on the severity of intrusion, underground construction can be eliminated from performance-assessment calculations.

\subsubsection{FEP Name: UNDERGROUND NUCLEAR TESTING}

Screening Criterion: Regulatory restrictions/consequence

Disposition: Screened out from scenario development

Discussion: Underground nuclear testing at the GCD location can be eliminated from performance assessments following the guidance of the Standard, because this type of human intrusion would be more severe than exploratory drilling for resources. Nuclear testing in the region would result in seismic waves reaching the GCD location, but these waves would be of no consequence to the performance of the disposal system. See discussion on Seismic Activity under Geologic FEPs and Appendix E.

\subsubsection{FEP Name: UNDETECTED PAST BOREHOLES}

Screening Criterion: Part of conceptual model 
Disposition: Screened out from scenario development

Discussion: Undetected past boreholes, if such features exist, are part of the conceptual model of the disposal system, and their possible presence is part of conceptual-model uncertainty and not part of scenario development. 
3.0 WASTE AND REPOSITORY INDUCED PHENOMENA

\subsection{CHEMICAL FEPS}

\subsubsection{FEP Name: BACKFILL EFFECTS ON CU CORROSION}

Screening Criterion: Applicability to disposal facility/waste form

Disposition: Screened out from scenario development

Discussion: The waste containers for GCD waste are not composed of copper. As a result, this FEP does not apply to the GCD facility.

\subsubsection{FEP Name: CHEMICAL REACTIONS}

Screening Criterion: Part of base case

Disposition: Base-case condition

Discussion: The capability for certain chemical reactions to occur must be built into the conceptual model of the disposal system so that under certain conditions, appropriate chemical reactions and their results can be determined.

\subsubsection{FEP Name: CHEMICAL TOXICITY OF WASTE}

Screening Criterion: Regulatory restrictions

Disposition: Screened out from scenario development

Discussion: The chemical toxicity of the waste is not relevant to addressing the Containment Requirements.

\subsubsection{FEP Name: COLLOID GENERATION SOURCE}

Screening Criterion: Part of conceptual model

Disposition: Screened out from scenario development

Discussion: Whether or not colloids form is a basic component of the source-term conceptual model. 


\subsubsection{FEP Name: COUPLED EFFECTS (ELECTROPHORESIS)}

Screening Criteria: Part of conceptual model

Disposition: Screened out from scenario development

Discussion: If coupled effects are important to the performance of the disposal system, these effects are incorporated into the modeling system and are not part of scenario development.

\subsubsection{FEP Name: CREEPING OF COPPER}

Screening Criterion: Applicability to waste form

Disposition: Screened out from scenario development

Discussion: Copper canisters were not used for the transport or storage of waste in the GCD boreholes.

\subsubsection{FEP Name: DECAY PRODUCT GAS GENERATION}

\section{Screening Criterion: Part of base case}

Disposition: Base-case condition

Discussion: Although none of the gaseous radionuclides disposed of at the GCD facility or produced by radioactive decay are addressed by the Containment Requirements, the generation of gas as a product of decay is a fundamental property of some radionuclides. As a result, this process is part of the base-case conditions of the source term.

\subsubsection{FEP Name: ELECTROCHEMICAL REACTIONS}

Screening Criterion: Applicability to waste form

Disposition: Screened out from scenario development

Discussion: Prij et al. (1991) base this FEP on the possible reaction between copper canisters and lead. Copper is not used as containers in the GCD disposal facility. As a result, consideration of this FEP is not appropriate for the GCD waste. 


\subsubsection{FEP Name: FIRE AND EXPLOSION OF WASTE AFTER BURIAL}

Screening Criterion: Physical reasonableness/consequence

Disposition: Screened out from scenario development

Discussion: GCD contains $94 \mathrm{~kg}$ of $\mathrm{LiH}$ (34 kg in Borehole No. 1, and $60 \mathrm{~kg}$ in Borehole No. 4), which can be explosive when in contact with water (Chu and Bernard, 1991). Price et al. (1993b) state that the limited flux of water through the unsaturated zone results in an explosion being unlikely. This conclusion on infiltration is supported by recent work with environmental tracers by Conrad (1993). In the event of possible increased infiltration resulting from wetter climatic conditions, especially with the disturbed sedimentary layering caused by the drilling of the boreholes, the consequences of reaction between the water and the $\mathrm{LiH}$ would be minor. Preliminary work by Santos-Torres (1991) indicates that the energy release by the reaction of $\mathrm{LiH}$ and water to form $\mathrm{LiOH}+\mathrm{H}_{2}$, based on a relatively high infiltration rate for the GCD environment, would not be sufficient to ignite the $\mathrm{H}_{2}$ byproduct. Soil and ground-water $\mathrm{pH}$ would increase immediately adjacent to where this reaction occurs. In summary, explosions as a result of water contacting $\mathrm{LiH}$ are not physically reasonable given the current understanding of the hydrologic conditions in the GCD boreholes. In the event that infiltration is or will be greater than predicted, the reaction of $\mathrm{LiH}$ with water is of low consequence.

One of the concerns of the New Mexico Environmental Evaluation Group is with respect to the transportation of TRU waste to the Waste Isolation Pilot Plant is the flammability and explosion potential of the waste. Silva $(1991,1992)$ cites several instances of fires and small-scale explosions of waste in individual storage containers attributed to the spontaneous ignition of pyrophoric radionuclides (e.g., uranium, plutonium, thorium, and possibly cerium and neodymium) either alone or in combination with other types of waste. With eight incidents reported for the many thousands of waste containers that have been used to store TRU waste over several decades, with the radionuclides in some of these incidents having acted as a fuel rather than an initiator for the incident, and with the specific conditions required for several, and possibly all, of the incidents to occur being physically impossible to reproduce in buried waste, the flammability and explosive potential for the TRU waste buried at the GCD location is not physically reasonable.

\subsubsection{FEP Name: I, CS-MIGRATION TO FUEL SURFACE}

Screening Criterion: Applicability to waste form/waste

Disposition: Screened out from scenario development 
Discussion: The initial inventory of GCD waste does not contain spent nuclear fuel, does not contain either I or Cs, and neither I nor Cs are produced within the decay chains of the waste in the inventory. As a result, this FEP is not applicable to the GCD waste.

\subsubsection{FEP Name: INTRODUCED COMPLEXING AGENT}

Screening Criterion: Response of disposal system

Disposition: Screened out from scenario development

Discussion: The modeling system should be designed to respond to such an addition if the addition of a complexing agent could affect the performance of the disposal system.

\subsubsection{FEP Name: LEACHING OF RADIONUCLIDES}

Screening Criterion: Part of conceptual model

Disposition: Screened out from scenario development

Discussion: The modeling capability to handle fluid leaching of radionuclides in the waste is part of the conceptual model of the disposal system and not part of scenario development.

\subsubsection{FEP Name: MICROBIAL EFFECTS}

Screening Criterion: Base-case condition

Disposition: Part of base-case scenario

Discussion: Some of the containers for the waste in the GCD boreholes are in part composed of fiberboard and plywood (Chu and Bernard, 1991). Microbes have been introduced to the boreholes with the waste and waste containers, and these microbes are assumed to degrade at least some of the organic materials in the containers and the waste. The possible consequences of microbial action on containment and radionuclide migration have not been determined.

\subsubsection{FEP Name: NEAR-FIELD BUFFER CHEMISTRY}

Screening Criterion: Part of conceptual model 
Disposition: Screened out from scenario development

Discussion: Near-field chemistry is part of the conceptual model of the disposal system.

\subsubsection{FEP Name: NONRADIOACTIVE SOLUTE IN GEOSPHERE}

Screening Criterion: Part of conceptual model

Disposition: Screened out from scenario development

Discussion: The composition of the solute in the geosphere must be included in the conceptual model of the disposal system.

\subsubsection{FEP Name: NUCLEAR CRITICALITY}

Screening Criterion: Physical reasonableness

Disposition: Screened out from scenario development

Discussion: Based on the distribution of concentrations of certain environmental tracers (Conrad, 1993), infiltration at the GCD location apparently is extremely low to nonexistent. Under wetter climatic conditions and with the natural layering of sediments disrupted at the borehole locations, an increase in the amount and rate of infiltration may occur. Water moving through the waste possibly could mobilize the radionuclides in the waste and reconcentrate the radionuclides at other locations within the disposal system leading to concerns over the possiblity of nuclear criticality. Analyses to evaluate the potential for nuclear criticality (Harms et al., in preparation) indicate that the physical conditions necessary for criticality to occur are not physically reasonable at the GCD location for the current inventory of TRU waste.

\subsubsection{FEP Name: OXIDIZING CONDITIONS}

Screening Criterion: Part of conceptual model

Disposition: Screened out from scenario development

Discussion: Eh, oxidizing potential, is a property of each of the media within the disposal system, and this property, along with uncertainty and the ability to adjust to changes, is part of the conceptual model of the system. 


\subsubsection{FEP Name: pH DEVIATIONS}

Screening Criterion: Part of conceptual model

Disposition: Screened out from scenario development

Discussion: $\mathrm{pH}$ is a property of each of the media within the disposal system, and this property, along with uncertainty and the ability to adjust to changes, is incorporated into the conceptual model of the system.

\subsubsection{FEP Name: PITTING}

Screening Criterion: Applicability to waste form

Disposition: Screened out from scenario development

Discussion: Pitting refers to the development of small holes in a metal canister containing nuclear waste, thereby compromising the isolation of the waste. The waste in the GCD boreholes was not placed in metal containers designed to contribute to the long-term isolation of the waste. Pitting is not a process that needs to be considered for GCD waste.

\subsubsection{FEP Name: RECONCENTRATION}

Screening Criterion: Response of disposal system

Disposition: Screened out from scenario development

Discussion: This FEP refers to the accumulation of radionuclides by precipitation or sorption within a confined volume along the transport path (Andersson et al., 1989). Reconcentration of any constituent of the waste requires transportation and deposition processes. These processes should be included within the conceptual model of the disposal system, and reconcentration should be a response of the disposal system to processes going on within the system.

\subsubsection{FEP Name: RECRYSTALLIZATION}

Screening Criterion: Process not adequately defined

Disposition: Screened out from scenario development

Discussion: No indication of what is supposed to recrystallize is provided in the original reference. 


\subsubsection{FEP Name: REDOX FRONT}

Screening Criterion: Part of conceptual model/response of disposal system

Disposition: Screened out from scenario development

Discussion: The existence of a redox front within the disposal system, if such a front exists and is important to the performance of the disposal system, can be incorporated into the conceptual model. If a redox front is to form during the evolution of the disposal system, the conceptual model should be able to accommodate this development.

\subsubsection{FEP Name: REDOX POTENTIAL}

Screening Criterion: Parameter name

Disposition: Screened out from scenario development

Discussion: Parameter names indicate possible input requirements to the modeling of the disposal system and are not included in scenario development.

\subsubsection{FEP Name: RELEASE OF RADIONUCLIDES FROM FAILED CANISTER}

Screening criterion: Applicability to waste form/waste

Disposition: Screened out from scenario development

Discussion: GCD waste is not in canisters designed to contribute to the isolation of the waste. Canister failure is not relevant to the performance-assessment analyses.

\subsubsection{FEP Name: SOLUBILITY LIMIT}

Screening Criterion: Parameter name

Disposition: Screened out from scenario development

Discussion: Parameter names indicate possible input requirements to models of the disposal system and are not events or processes used to develop scenarios. 


\subsection{THERMAL FEPS}

\subsubsection{FEP Name: BRINE MIGRATION}

Screening Criterion: Applicability to geologic setting

Disposition: Screened out from scenario development

Discussion: Brine migration refers to the movement of brine inclusions in salt crystals in response to an imposed thermal gradient. Brine inclusions have not been identified in the salts within the soils at the GCD location.

\subsubsection{FEP Name: CONVECTION}

Screening Criterion: Part of conceptual model

Disposition: Screened out from scenario development

Discussion: If thermal convection significantly affects the movement of fluids in either the saturated or unsaturated zones, this process should be incorporated in the conceptual model of the disposal system.

\subsubsection{FEP Name: DEHYDRATION OF SALT MINERALS}

Screening Criterion: Consequence

Disposition: Screened out from scenario development

Discussion: Although minor salt $(\mathrm{NaCl})$ accumulations are likely to occur at depth in well-drained soil horizons (Birkeland, 1984), the loss of any moisture associated with these layers would have no recognizable affects on the performance of the disposal system.

\subsubsection{FEP Name: DIFFERENTIAL ELASTIC RESPONSE}

Screening Criterion: Applicability to geologic setting

Disposition: Screened out from scenario development

Discussion: Unconsolidated sediments at the GCD location are not likely to respond elastically to heating and cooling because of intergranular adjustments to volume changes. 


\subsubsection{FEP Name: FLUID MIGRATION}

Screening Criterion: Part of conceptual model

Disposition: Screened out from scenario development

Discussion: Any thermal effects caused by waste-generated heat that are expected to affect the movement of fluids should be incorporated into the conceptual model of the disposal system.

\subsubsection{FEP Name: FLUID PRESSURE, DENSITY, VISCOSITY CHANGES}

Screening Criterion: Part of conceptual model

Disposition: Screened out from scenario development

Discussion: The capability to account for any changes in fluid pressure, density, and viscosity resulting from thermal effects that are determined to be important in performance calculations should be incorporated into the conceptual model of the disposal system.

\subsubsection{FEP Name: FRACTURE APERTURE CHANGES}

Screening Criterion: Applicability to geologic setting

Disposition: Screened out from scenario development

Discussion: No observations of fractures in the alluvial-fan deposits have been reported at the GCD location. If such fractures do exist, the changes to fracture aperture because of the thermal effects of the waste would be a capability included in the conceptual model of the disposal system.

\subsubsection{FEP Name: HEAT PRODUCTION}

Screening Criterion: Base-case condition

Disposition: Part of base-case scenario

Discussion: Heat production is an inherent property of at least some of the waste at the GCD location, although the most significant source of waste-generated heat is the waste in GCDT. As a result, heat production will occur, and this process is a base-case condition and needs to be considered in this context. 


\subsubsection{FEP Name: INDUCED HYDROLOGIC CHANGES}

Screening Criterion: Response of disposal system/Base-case condition

Disposition: Screened out from scenario development/Part of base-case scenario

Discussion: Changes to the hydrologic conditions at the GCD caused by wastegenerated heat is a response to the heat that can be modeled. The capability to model changes in hydrologic conditions should be included in the conceptual model of the base-case scenario, if these types of changes occur and are potentially important to the performance of the disposal system.

\subsubsection{FEP Name: INTERNAL PRESSURE}

Screening Criterion: Applicability to geologic setting

Disposition: Screened out from scenario development

Discussion: Both the intact and disturbed basin-fill deposits at the GCD location have relatively high lateral permeabilities. In addition, the waste containers are not designed to contribute to the long-term isolation of the waste. For this reason, gas pressure will not build up as a result of the increase in temperature caused by the presence of the waste.

\subsubsection{FEP Name: MIGRATION OF INTRACRYSTALLINE BRINE INCLUSIONS}

Screening Criterion: Applicability to geologic setting

Disposition: Screened out from scenario development

Discussion: Brine inclusions have not been identified in and are not expected to be present within the trace quantities of salt in the basin-fill deposits at the GCD disposal location. This FEP is intended for consideration when evaluating disposal systems in bedded-salt units and possibly domed-salt structures.

\subsubsection{FEP Name: NONELASTIC RESPONSE}

Screening Criterion: Part of conceptual model

Disposition: Screened out from scenario development

Discussion: The thermal response of the materials at the GCD, either elastic or nonelastic, are material properties that are incorporated into the conceptual model 
of the disposal system if these responses have an effect on the performance of the system.

\subsubsection{FEP Name: THERMAL CHANGES IN BURIAL ZONE CAUSED BY HEAT GENERATION}

Screening Criterion: Base-case condition

Disposition: Part of base-case scenario

Discussion: Heat generated by radioactive decay is a fundamental property of the waste. Any effects of this heat on the host material is part of the base case. The capability to account for changes should be included in the conceptual model of the disposal system if these changes are determined to be significant.

\subsubsection{FEP Name: THERMAL CRACKING}

Screening Criterion: Applicability to geologic setting

Disposition: Screened out from scenario development

Discussion: The alluvial-fan material surrounding the waste should accommodate thermal expansion and contraction by intergranular movement rather than fracturing.

\subsubsection{FEP Name: THERMAL EFFECTS}

Screening Criterion: Applicability to disposal facility

Disposition: Screened out from scenario development

Discussion: This FEP was originally identified to consider the possible effect of heat generated by the dehydration of the concrete used in the repository (Prij et al., 1991). Concrete has not been used in the construction of the GCD boreholes as storage facilities, and Prij et al. (1991) concluded that thermal effects from this source are not expected for deep repositories where concrete may be used.

\subsubsection{FEP Name: THERMAL EFFECTS ON BUFFER MATERIAL}

Screening Criterion: Applicability to disposal facility

Disposition: Screened out from scenario development 
Discussion: No buffer material was used in the disposal boreholes.

\subsubsection{FEP Name: THERMOCHEMICAL CHANGES}

Screening Criterion: Part of conceptual model

Disposition: Screened out from scenario development

Discussion: Thermochemical changes include the effect of temperature changes on chemical equilibria and reaction kinetics. Because heat is generated during radioactive decay, these changes are part of the base case. If thermochemical changes have a significant effect on the performance of the disposal system, the capability to address these changes should be incorporated into the conceptual model of the system. 


\subsection{MECHANICAL FEPS}

\subsubsection{FEP Name: CANISTER DEFECTS}

Screening Criterion: Applicability to waste form

Disposition: Screened out from scenario development

Discussion: This FEP is specifically intended for HLW and SF disposal in metal canisters that are designed to be part of the barrier system. The waste currently in the GCD boreholes was shipped to this location in a variety of types of containers, including plywood boxes coated with fiberglass and fiberboard liners within steel drums (Chu and Bernard, 1991). These containers were designed to assure containment of the waste during short-term, on-site storage and during shipment of the waste to the GCD location. Containers were not designed to be part of the barrier system during long-term disposal. For the purposes of performance assessments, these containers will be assumed to play no role in the containment of radionuclides. Because the waste stored at the GCD facility is not in canisters, canister defects are not relevant to performance analyses.

\subsubsection{FEP Name: CANISTER OR CONTAINER MOVEMENT}

Screening Criterion: Applicability to geologic setting/waste form

Disposition: Screened out from scenario development

Discussion: With the possible exception of compaction, no mechanism has been identified by which the waste containers in the GCD disposal system could move within the surrounding alluvial-fan deposits.

\subsubsection{FEP Name: CHANGES IN IN-SITU STRESS FIELD}

Screening Criterion: Response of disposal system

Disposition: Screened out from scenario development

Discussion: Changes in the in-situ stress field are responses to something else happening. The capability to include the effects of these changes on the disposal system should be included in the conceptual model of the disposal system if these changes are significant. 


\subsubsection{FEP Name: CONVERGENCE OF OPENINGS}

Screening Criterion: Applicability to disposal system

Disposition: Screened out from scenario development

Discussion: This FEP refers to the tendency of salt creep to close openings at depth in response to stress differentials (Prij et al., 1991). Because the GCD facility is not in salt, this FEP is not applicable to the GCD disposal system.

\subsubsection{FEP Name: DAMAGED OR DEVIATING FUEL}

Screening Criterion: Applicability to waste form

Disposition: Screened out from scenario development

Discussion: Nuclear-reactor fuel is not present at the GCD.

\subsubsection{FEP Name: DEGRADATION OF BOREHOLE AND SHAFT SEALS}

Screening Criterion: Applicability to disposal facility

Disposition: Screened out from scenario development

Discussion: GCD boreholes do not contain seals specifically designed to contribute to the isolation of the waste (Price et al., 1993b). Once the holes were drilled and filled with waste, probertite was emplaced around the TRU waste and disturbed material generated by the drilling of the boreholes was used as backfill for the remainder of the boreholes. With no specific seals in the GCD boreholes, this FEP is not applicable to the GCD disposal facility.

\subsubsection{FEP Name: DESIGN MODIFICATION}

Screening Criterion: Part of conceptual model

Disposition: Screened out from scenario development

Discussion: Preclosure modifications of the design of the disposal facility are part of the conceptual model of the disposal system. Postclosure modifications are covered under the FEP named Attempt At Site Improvement, which is listed under 3.3 Postclosure Subsurface FEPs. 


\subsubsection{FEP Name: DEWATERING OF HOST ROCK [SEDIMENTS]}

Screening Criterion: Response of disposal system

Disposition: Screened out from scenario development

Discussion: Dewatering is a response to a change in the disposal system. If dewatering is determined to be important in system performance, the capability to address this process should be included in the conceptual model of the disposal system.

\subsubsection{FEP Name: EMBRITTLEMENT, CRACKING}

Screening Criterion: Applicability to waste form

Disposition: Screened out from scenario development

Discussion: Waste containers are not part of the barrier system for GCD waste.

\subsubsection{FEP Name: FRACTURING}

Screening Criterion: Part of conceptual model

Disposition: Screened out from scenario development

Discussion: Fracturing of either the host rock or the waste canisters is the result of some event or process occurring. The capability of fracture formation should be a capability of the conceptual model of the appropriate event or process.

\subsubsection{FEP Name: LOSS OF DUCTILITY}

Screening Criterion: Applicability to waste form

Disposition: Screened out from scenario development

Discussion: This FEP refers to the loss of ductility of the metal canister containing the waste as a mechanism of compromising one if the barriers in the disposal system. This FEP is not applicable to the GCD waste that was not placed in metal canisters prior to disposal. The metal containers used for disposal of GCD waste are not designed to contribute to the long-term isolation of the waste and no credit toward isolation of the waste is assumed for the containers, so loss of ductility is not relevant to performance calculations. 


\subsubsection{FEP Name: MATERIAL DEFECTS}

Screening Criterion: Part of conceptual model

Disposition: Screened out from scenario development

Discussion: Postclosure conditions with respect to material properties (including uncertainties) are part of the conceptual model of the disposal system.

\subsubsection{FEP Name: MECHANICAL FAILURE OF BUFFER/BACKFILL}

Screening Criterion: Applicability to disposal facility

Disposition: Screened out from scenario development

Discussion: With the possible exception of a fault penetrating a GCD borehole, the backfill within these boreholes is not likely to mechanically fail (i.e., fracture) on a long-term basis, because the material is poorly consolidated to unconsolidated and can accommodate changes in the stress field by intergranular movement. Possible failure because of faulting is considered under the heading Fault Activation/Fault Generation.

\subsubsection{FEP Name: MECHANICAL FAILURE OF REPOSITORY}

Screening Criterion: Applicability to disposal facility

Disposition: Screened out from scenario development

Discussion: Mechanical failure of the repository refers to the formation of fractures or faults as a result of improper reinforcement of the excavations (Andersson et al., 1989). This type of failure is not consistent with the design of the GCD disposal facility.

\subsubsection{FEP Name: READJUSTMENT OF ROCK ALONG JOINTS}

Screening Criterion: Applicability to geologic setting

Disposition: Screened out from scenario development

Discussion: The GCD facility is located in alluvial-fan deposits, not fractured rocks. 


\subsubsection{FEP Name: ROLE OF EVENTUAL CHANNELING WITHIN THE CANISTER}

Screening Criterion: Applicability to waste form

Disposition: Screened out from scenario development

Discussion: Metal GCD waste containers are not designed to contribute to the long-term isolation of the waste. For this reason, channeling, which would compromise the containers' barrier function, is not relevant to the disposal of waste at the GCD location.

\subsubsection{FEP Name: STRESS CORROSION CRACKING}

Screening Criterion: Applicability to waste form

Disposition: Screened out from scenario development

Discussion: Metal GCD waste containers are not designed to contribute to the long-term isolation of the waste. For this reason, stress corrosion cracking, which would compromise the containers' barrier function, is not relevant to the disposal of waste at the GCD location.

\subsubsection{FEP Name: SUBSIDENCE OF CANISTER}

Screening Criterion: Applicability to waste form

Disposition: Screened out from scenario developnent

Discussion: GCD waste containers are not designed to contribute to the long-term isolation of the waste. Subsidence of the containers in response to the weight of the overburden is expected to occur. Compaction of the waste containers and the waste is considered under the heading Subsidence/Caving.

\subsubsection{FEP Name: SUBSIDENCE OR CAVING}

Screening Criterion: None

Disposition: Retained for scenario development

Discussion: The waste containers and the backfill in both the GCD boreholes and the LLW trenches within the RWMS may compact with time. One result of compaction would be subsidence at the surface. Subsidence could form 
depressions where precipitation or surface runoff could accumulate and serve as points of enhanced infiltration. Pending an evaluation of the extent of subsidence for the boreholes and the effects of caps placed over the trenches and perhaps the boreholes at closure, subsidence cannot be eliminated from scenario development on the basis of physical reasonableness or low probability, and consequence analyses have not been performed at this time on the effects of subsidence.

If subsidence can result in significant consequences, probability of occurrence will play an important role in determining how subsidence is handled in performance assessments. If subsidence is certain to occur and be completed within the assumed 100 years of active, postclosure institutional controls, subsidence is part of the base-case scenario. If subsidence is certain to occur after the 100 years of active controls, subsidence remains part of the base-case scenario. If uncertainty exists as to whether subsidence will or will not occur after the assumed end of institutional controls, this FEP is used in scenario development.

\subsubsection{FEP Name: SUDDEN ENERGY RELEASE}

Screening Criterion: Regulatory restrictions

Physical reasonableness

Disposition: Screened out from scenario development

Discussion: This event refers to sabotage during the operational period (Andersson et al., 1989). Performance assessments do not include consideration of preclosure events. This FEP can be eliminated from consideration on the basis of regulatory restrictions.

Andersson et al. (1989) also considered the sudden release of lattice energy stored in spent nuclear fuel, but concluded that this type of energy release is not possible. With this FEP not physically possible for the higher concentrations and quantities of radionuclides in spent nuclear fuel, this FEP is not physically reasonable for the TRU waste in the GCD boreholes.

\subsubsection{FEP Name: SWELLING OF BACKFILL (CLAY)}

Screening Criterion: Applicability to disposal facility

Disposition: Screened out from scenario development

Discussion: This FEP was intended to address the usage of bentonite as a backfill material in repositories. Bentonite clay tends to swell upon absorbing water. Bentonite was not used in the TRU boreholes at the GCD disposal facility. In 
strict definition of this FEP, Swelling of Backfill is not applicable to the GCD disposal facility.

Probertite, which also is a clay, was selected as backfill material in the TRU boreholes to address concerns about possible nuclear criticality by acting as an absorber of emitted neutrons. Any swelling of the probertite in response to ground water or the high interstitial humidity in the unsaturated zone is not relevant to the performance of the disposal system.

\subsubsection{FEP Name: SWELLING OF BENTONITE INTO TUNNELS AND CRACKS}

Screening Criterion: Applicability to disposal system

Disposition: Screened out from scenario development

Discussion: Bentonite has not been used as backfill material in the GCD boreholes.

\subsubsection{FEP Name: SWELLING OF CORROSION PRODUCTS}

Screening Criterion: Consequence

Disposition: Screened out from scenario development

Discussion: As the GCD waste and the metallic waste containers oxidize (corrode), the materials will increase in volume. Corrosion will also degrade the structural strength of the containers resulting in their compaction. The magnitude of the compaction is likely to be substantially greater than the volume increase by corrosion-product expansion. The origin of this FEP is a concern about the effect of corrosion on canister integrity. Containers for the GCD waste were not designed to be part of the containment system. Swelling of corrosion products will be of no consequence to the performance of the GCD disposal system. 


\subsection{RADIOLOGICAL FEPS}

\subsubsection{FEP Name: MATERIAL PROPERTY CHANGE}

Screening Criterion: Part of conceptual model

Disposition: Screened out from scenario development

Discussion: Changes in material properties resulting from irradiation should be a capability built into the conceptual model of the disposal system.

\subsubsection{FEP Name: RADIATION EFFECTS ON BENTONITE}

Screening Criterion: Applicability to disposal facility

Disposition: Screened out from scenario development

Discussion: Bentonite has not been used as backfill material for the GCD boreholes.

\subsubsection{FEP Name: RADIATION EFFECTS ON CANISTER}

Screening Criterion: Applicability to waste form

Disposition: Screened out from scenario development

Discussion: The containers used for GCD waste are not assumed to contribute to the isolation of the waste. Degradation of the containers in response to exposure to radiation is not a consideration in performance assessments for GCD disposal system.

\subsubsection{FEP Name: RADIOACTIVE DECAY AND INGROWTH (CHAIN DECAY)}

Screening Criterion: Base-case condition

Disposition: Part of base-case scenario

Discussion: This FEP refers to the decay chains of the radionuclides present in the original waste at the time of disposal. The certainty of radioactive decay places this FEP in the base-case scenario. 


\subsubsection{FEP Name: RADIOLYSIS}

Screening Criterion: Base-case condition

Disposition: Part of base-case scenario

Discussion: Dissociation of water molecules is likely to occur in the immediate vicinity of the inore active waste placing this process in the base case. This process needs to be evaluated for its effect on the performance of the disposal system.

\subsubsection{FEP Name: RECOIL OF ALPHA-DECAY}

\section{Screening Criterion: Applicability to waste}

Disposition: Screened out from scenario development

Discussion: This process concerns the possible destruction of fuel-pellet structure by high energy alpha particles from alpha decay and the possible liberation of atoms from the fuel surface (Andersson et al., 1989). Andersson et al. (1989) concluded that alpha decay could not affect the pellet structure, and the effect on solubility could be handled through solubility estimates of radionuclides. GCD waste does not include fuel pellets.

\subsubsection{FEP Name: RELEASE OF STORED ENERGY}

Screening Criterion: Consequence

Disposition: Screened out from scenario development

Discussion: This FEP is based on a portion of the gamma energy released by the radioactive portion of the waste causing the formation of lattice defects in salt crystals, which results in the disintegration of $\mathrm{NaCl}$ into colloidal sodium and chlorine. Energy would be released upon recombination on $\mathrm{Na}$ and $\mathrm{Cl}$. GCD waste does contain gamma-emitting radionuclides (Chu and Bernard, 1991), but $\mathrm{NaCl}$ present in soil horizons is in such minor quantities that even if a mechanism of sudden energy release does exist and occurs, the consequence on the disposal system would be insignificant. 


\subsection{IMPROPER DESIGN AND OPERATION FEPS}

\subsubsection{FEP Name: BACKFILL MATERIAL DEFICIENCIES}

Screening Criterion: Response of disposal system

Disposition: Screened out from scenario development

Discussion: The backfill material has certain material properties. If the backfill is the primary barrier to the release of radionuclides to the accessible environment, "adequacy" or "deficiency" can only be determined by modeling the disposal system to determine whether the radionuclide releases are "acceptable" relative to the performance criteria.

\subsubsection{FEP Name: COAGULATION OF BENTONITE}

Screening Criterion: Applicability to disposal facility

Disposition: Screened out from scenario development

Discussion: Bentonite has not been used as backfill material for the GCD boreholes.

\subsubsection{FEP Name: IMPROPER WASTE EMPLACEMENT}

Screening Criterion: Applicability to disposal facility

Disposition: Screened out from scenario development

Discussion: The waste is already emplaced in the GCD boreholes. No "proper" or "improper" arrangement of waste had any meaning at the time of waste emplacement. Through performance assessments, alternate arrangements of the waste that could result in lower releases to the accessible environment in the event of human intrusion may be identified.

\subsubsection{FEP Name: SEDIMENTATION OF BENTONITE}

Screening Criterion: Applicability to disposal facility

Disposition: Screened out from scenario development

Discussion: Bentonite has not been used as backfill for the GCD boreholes. 


\section{REFERENCES}

Andersson, J., T. Carlsson, T. Eng, F. Kautsky, E. Söderman, and S. Wingefors, 1989. The Joint SKI/SKB Scenario Development Project, SKB-TR89-35, Svensk Kärnbränslehantering Ab, Stockholm, Sweden.

Bates, R.L., and J.A. Jackson, 1987. Glossary of Geology (3rd ed.), American Geological Institute, Alexandria, VA.

Birkeland, P.W., 1984. Soils and Geomorphology, Oxford University Press, New York, NY.

Bonilla, M.G., 1979. "Historic Surface Faulting; Map Patterns, Relation to Subsurface Faulting, and Relation to Preexisting Faults," in Proceedings of Conference VIII; Analysis of Actual Fault Zones in Bedrock, April 1-5, 1979, Palm Springs, CA, Open File Report 79-1239, U.S. Geological Survey, Denver, CO, p. 36-65.

Carr, W.J., G.D. Bath, D.L. Healey, and R.M. Hazelwood, 1975. Geology of Northern Frenchman Flat, Nevada Test Site, USGS-474-216, U.S. Geological Survey, Denver, $\mathrm{CO}$.

Case, C., J. Davis, R. French, and S. Raker, 1984. Site Characterization in Connection with the Low Level Defense Waste Management Site in Area 5 of the Nevada Test Site, Nye County, Nevada--Final Report, DOE/NV/10162-13, Water Resources Center, Desert Research Institute, Reno, NV.

Chu, M.S.Y., and E.A. Bernard, 1991. Waste Inventory and Preliminary Source Term Model for the Greater Confinement Disposal Site at the Nevada Test Site, SAND91-0170, Sandia National Laboratories, Albuquerque, NM.

Claiborne, H.C., and F. Gera, 1974. Potential Containment Failure Mechanisms and Their Consequences at a Radioactive Waste Repository in Bedded Salt in New Mexico, ORNL-TM-4639, Oak Ridge National Laboratory, Oak Ridge, TN.

Conrad, S.H., 1993. "Using Environmental Tracers to Estimate Recharge Through an Arid Basin," in Proceedings of the Fourth Annual International Conference on High Level Radioactive Waste Management, April 26-30, 1993, Las Vegas, NV, American Nuclear Society, Inc., La Grange Park, IL, Vol. 1, p. 132-137.

Craig, R.G., B.L. Roberts, and M.P. Singer, 1984. Climates and Lakes of the Death Valley Drainage System during the Last Glacial Maximum, Unpublished Report, Department of Geology, Kent State University, Kent, OH. 
Cranwell, R.M., R.V. Guzowski, J.E. Campbell, and N.R. Ortiz, 1990. Risk Methodology for Geologic Disposal of Radioactive Waste: Scenario Selection Procedure, NUREG/CR-1667 (SAND80-1429), Sandia National Laboratories, Albuquerque, NM. (Original version of this report published in 1982 under same title and report numbers).

Gustafson, D.L., S.E. Rawlinson, and J.J. Miller, 1993a. Summary of Natural Resources That Potentially Influence Human Intrusion at the Area 5 Radioactive Waste Management Site DOE/Nevada Test Site, Nye County, Nevada, Raytheon Services Nevada, Las Vegas, NV.

Gustafson, D.L., S.M. Parsons, and K.E. Snyder, 1993b. Greater Confinement Disposal Borehole Logging at the Area 5 Radioactive Waste Management Site DOE Nevada Test Site, Nye County, Nevada, Raytheon Services Nevada, Las Vegas, NV.

Harms, G., R. Coats, and R.V. Guzowski, in preparation. An Assessment of Nuclear Criticality as a Factor in Scenario Development in Performance Assessments for the Greater Confinement Disposal Facility, Area 5 of the Nevada Test Site, Sandia National Laboratories, Albuquerque, NM.

Hartmann, W.K., 1979. Long-Term Meteorite Hazards to Buried Nuclear Waste, PNL2851, Pacific Northwest Laboratory, Richland, WA, p. VI-1 through VI-15.

Hora, S.C., D. von Winterfeldt, and K.M. Trauth. 1991. Expert Judgment on Inadvertent Human Intrusion into the Waste Isolation Pilot Plant, SAND90-3063, Sandia National Laboratories, Albuquerque, NM.

Hudson, M.R., 1992. "Paleomagnetic Data Bearing on the Origin of Arcuate Structures in the French Peak--Massachusetts Mountain of Southern Nevada," Geological Society of America Bulletin, Vol. 104(5), p. 581-594.

Izett, G.A., J.D. Obradovich, and H.H. Mehnert, 1988. The Bishop Ash (Middle Pleistocene) and Some Older (Pliocene and Pleistocene) Chemically and Mineralogically Similar Ash Beds in California, Nevada, and Utah, Bulletin 1675, U.S. Geological Survey, Denver, CO.

Kärnbränslesakerhet, 1978. Handling of Spent Nuclear Fuel and Final Storage of Vitrified High Level Reprocessing Waste, Kärnbränslesakerhet, Stockholm, Sweden.

Logan, S.E., and M.C. Berbano, 1978. Development and Application of a Risk Assessment Method for Radioactive Waste Management, Volume II: 
Implementation for Terminal Storage in Reference Repository and Other Applications, EPA 520/6-78-005, U.S. Environmental Protection Agency, Washington, D.C.

Mifflin, M.D., and M.M. Wheat, 1979. Pluvial Lakes and Estimated Pluvial Climates of Nevada, Bulletin 94, Nevada Bureau of Mines and Geology, Reno, NV.

Muffler, L.J.P., ed., 1979. Assessment of Geothermal Resources of the United States-

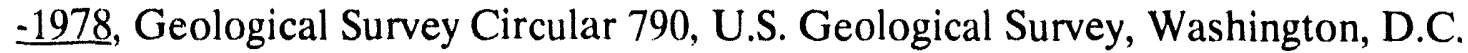

Price, L.L., S.H. Conrad, D.A. Zimmerman, N.E. Olague, K.C. Gaither, W.B. Cox, J.T. McCord, and C.P. Harlan, 1993a. Preliminary Performance Assessment of the Greater Confinement Disposal Facility at the Nevada Test Site. Volume 2: Technical Discussion, SAND91-0047, Sandia National Laboratories, Albuquerque, NM.

Price, L.L., D.A. Zimmerman, N.E. Olague, S.H. Conrad, and C.P. Harlan, 1993 b. Preliminary Performance Assessment of the Greater Confinement Disposal Facility at the Nevada Test Site. Volume 3: Supporting Details, SAND91-0047, Sandia National Laboratories, Albuquerque, NM.

Prij, J., B. Blok, D. Fraters, P. Glasbergen, G.M.H. Laheij, W. Slagter, A.F.M. Slot, P. Uijt de Haag, H. van de Weerd, A.F.B. Wildenborg, and D. Zanstra, 1991. PROSA: PRobabilistisch Onderzoek aan de veiligheid van in Steenzout opgeborgen radioactief Afval, Concept Tussenrapport 4, Scenario Selectie, Energieonderzoek Centrum Nederland, Petten, the Netherland.

Rawlinson, S.E., 1993. Transmittal of Comments Regarding Performance Assessment and Geologic Studies at the Area 5 Radioactive Waste Management Site, Letter to P. Davis, Waste Management Systems Department, Sandia National Laboratories, dated August 26, 1993, Raytheon Services Nevada, Las Vegas, NV.

Richard-Haggard, K., 1983. Economic Potential of Alternative Land and Natural Resource Uses at the Nevada Test Site, Nye County, Nevada, DOE/NV/10162-8, Desert Research Institute, Reno, NV.

RSN (Raytheon Services Nevada), 1991. Surficial Geology of the Area 5 Radioactive Waste Management Site. Interim Report Review Draft, Raytheon Services Nevada, Las Vegas, NV.

Santos-Torres, A.E., 1991. Lithium Hydride in a Borehole, Unpublished Report, Sandia National Laboratories, Albuquerque, NM. 
Silva, M., 1991. An Assessment of the Flammability and Explosion rotential of Transuranic Waste, EEG-48, New Mexico Environmental Evaluation Group, Albuquerque, NM.

Silva, M., 1992. "An Assessment of the Flammability and Explosion Potential of Defense Transuranic Waste," Nuclear Safety, Vol. 33, no. 2, 220-228.

Smith, C.B., D.J. Egan, Jr., W.A. Williams, J.M. Grunlke, C.-Y. Hung, and B.L. Serini, 1982. Population Risks from Disposal of High-Level Radioactive Wastes in Geologic Repositories, EPA 520/3-80-006, U.S. Environmental Protection Agency, Washington, D.C.

Snyder, K.E., S.M. Parsons, and D.L. Gustafson, 1993. Field Results of Subsurface Geologic Mapping at the Area 5 Radioactive Waste Management Site DOE Nevada Test Site, Nye County, Nevada, Raytheon Services Nevada, Las Vegas, NV.

U.S. EPA (Environmental Protection Agency), 1985. "Environmental Standards for the Management anu Disposal of Spent Nuclear Fuel, High-Level and Transuranic Radioactive Wastes; Final Rule, 40 CFR Part 191," Federal Register, Vol. 50, no. 182 , p. 38066-38089.

Winograd, I.J., and W. Thordarson, 1975. Hydrogeologic and Hydrochemical Framework, South-Central Great Basin, Nevada-California, with Special Reference to the Nevada Test Site, Open-File Report 80-569, U.S. Geological Survey, Washington, D.C. 
APPENDIX E

SEISMICITY IN THE NTS REGION

E-1 


\section{E-2}




\section{APPENDIX E: SEISMIC ACTIVITY IN THE NTS REGION}

An evaluation of the seismic activity of the Nevada Test Site (NTS) region has been made by Vortman (1991) as part of the Yucca Mountain Site Characterization Project. This evaluation is primarily based on two data bases, the Southern Nevada Seismograph Network (SNSN) and the Southern Great Basin Historical Catalogue (SGBHC). These data bases record a total of 11,988 seismic events within an approximately 200 -kilometer radius of NTS dating from as early as 1868 and include both naturally occurring and human-induced events. Because of the relatively recent development and deployment of equipment capable of detecting low-magnitude seismic events that cannot be felt by individuals in the area, the actual number of events that occurred within this area is much larger than the number recorded in the data bases. The naturally occurring events are associated with the tectonic activity characteristic for this part of the Great Basin. Human-induced events originate from (1) the filling of Lake Mead, which started in 1936, (2) high-explosive test explosions caused by mining at Bare Mountain and both the construction and operation of an Air Force shock tube at Little Skull Mountain, (3) underground nuclear explosions (UNE) within NTS, (4) postUNE cavity collapses, which have been observed as long as 2,604 days after a test, and (5) aftershocks, which are small earthquakes, caused by UNEs. A concern in considering the seismicity of the NTS region is distinguishing naturally occurring earthquakes from aftershocks caused by UNEs. According to Vortman (1991), aftershocks are caused by an area adjusting to the stresses imposed by a UNE rather than by a release of accumulated tectonic stresses. The distance to a critical stress scales as the cube root of the yield of the UNE (Vortman, 1991).

Of the 11,988 seismic events in the data bases, 3,827 events were concluded to be human induced with the remaining 8,161 events primarily of natural origin. Of the remaining events, an additional 1,432 either have no recorded magnitude or the location has a large error. Some human-induced events could not be identified as such. For example, Vortman (1991) mentions that the data bases included 85 nuclear explosions, but unannounced shots were not included. The number of explosions listed in the data bases may be much larger, because between 1957 when the first UNE was tested at NTS and the end of 1986, 540 UNEs occurred at NTS exclusive of the unannounced tests (Nevada Operations Office, 1987). Vortman (1991) did not mention why only 85 UNEs occur in the data bases.

The southeastern portion of NTS is highly seismic, although the magnitudes of the earthquakes tend to be relatively low. Figures E-1 through E-8 demonstrate the distribution and magnitude of earthquakes using the data in the SGBHC data base. In the figures, "Historical All" includes both naturally occurring and human-induced seismic events, and "Modified Historical" includes only naturally occurring earthquakes. The SNSN data base, which covers a shorter time period than the SGBHC data base, contains no naturally occurring earthquakes with magnitudes greater than 3.0 within the 
boundaries of NTS. Only two earthquakes with magnitudes greater than 6.0 have been recorded in the region. A magnitude 6.3 earthquake occurred 140 kilometers from Yucca Mountain in 1868, and another magnitude 6.3 earthquake occurred 187 kilometers from Yucca Mountain in 1910. Neither of these earthquakes was within 125 kilometers of the NTS boundary. 


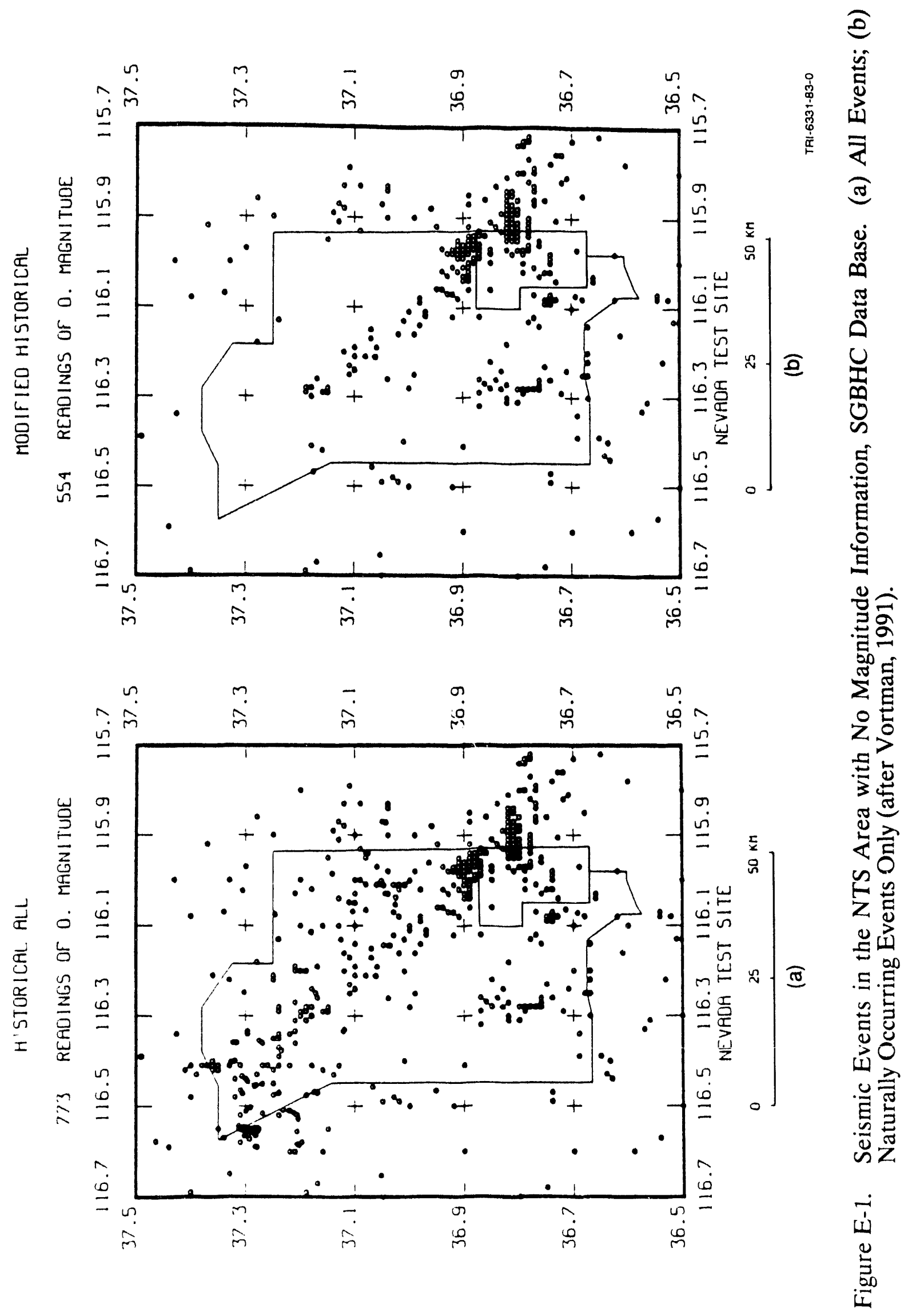

E-5 


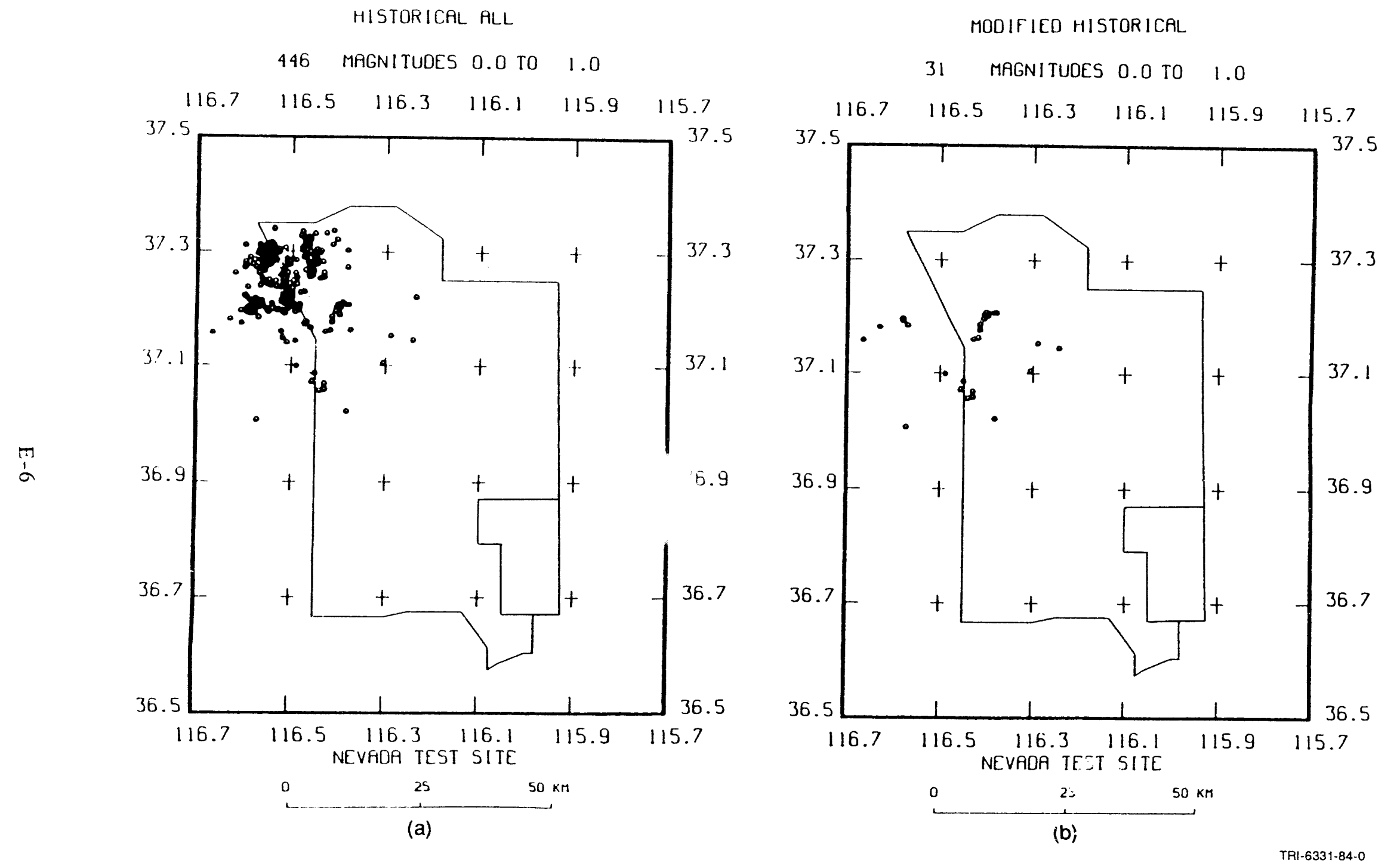

Figure E-2. Seismic Events in the NTS Area with Magnitudes from 0.0 to 1.0, SGBHC Data Base. (a) All Events; (b) Naturally Occurring Events Only (after Vortman, 1991). 

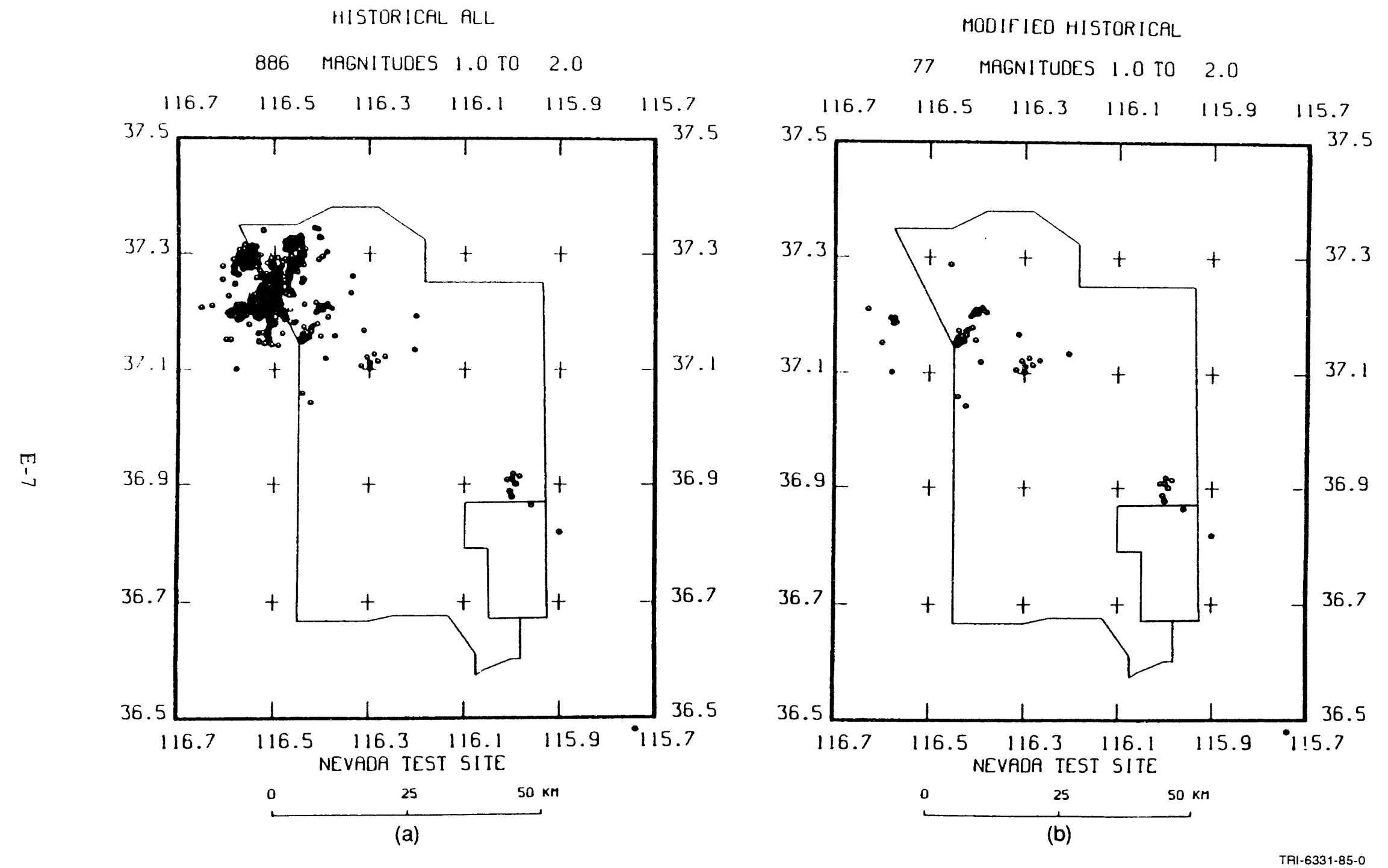

Figure E-3. Seismic Events in the NTS Area with Magnitudes from 1.0 to 2.0, SGBHC Data Base. (a) All Events; (b) Naturally Occurring Events Only (after Vortman, 1991). 


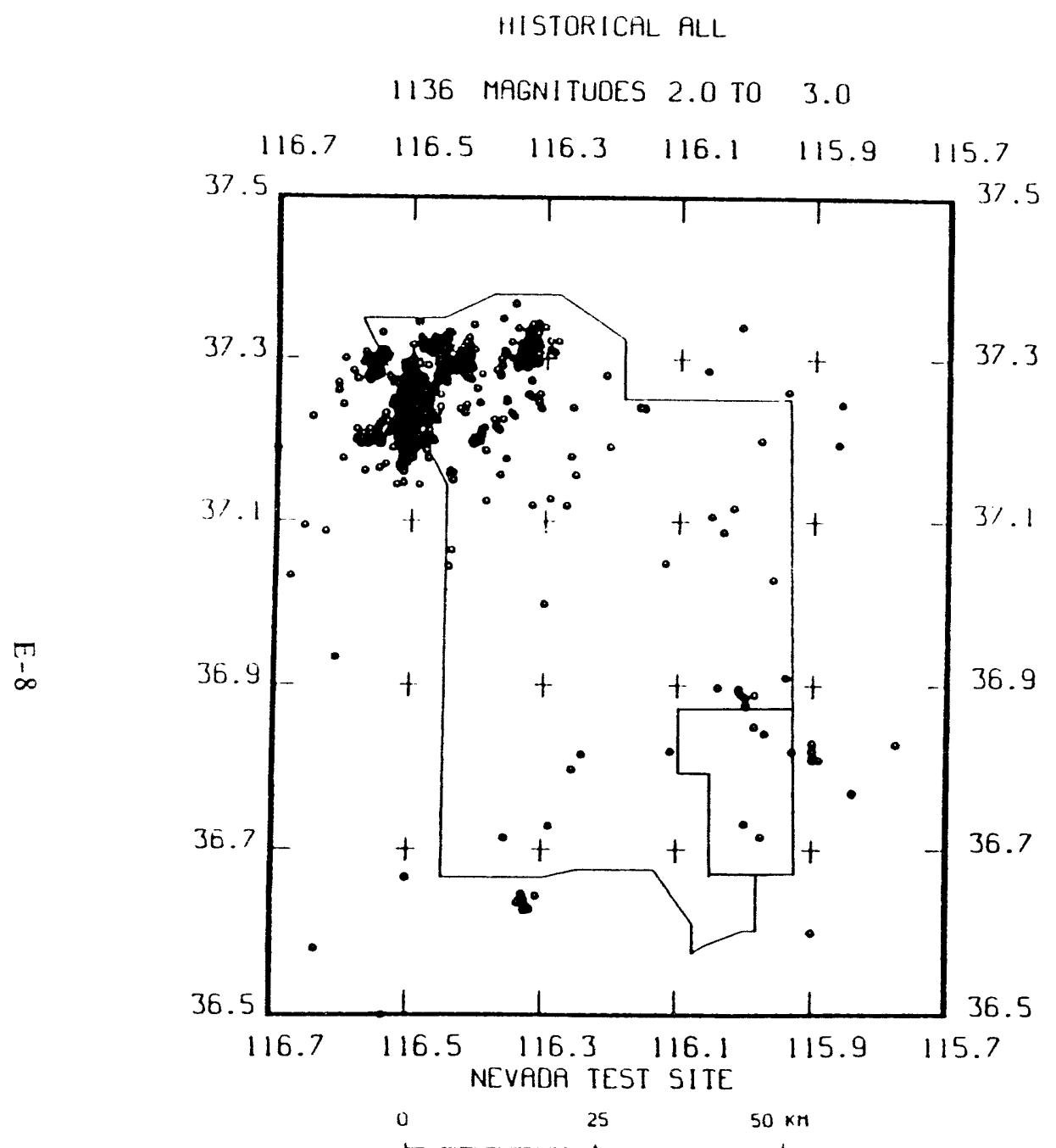

(a)
MODIFIED HISTORICAL

79 MAGNITUDES 2.0 TO 3.0

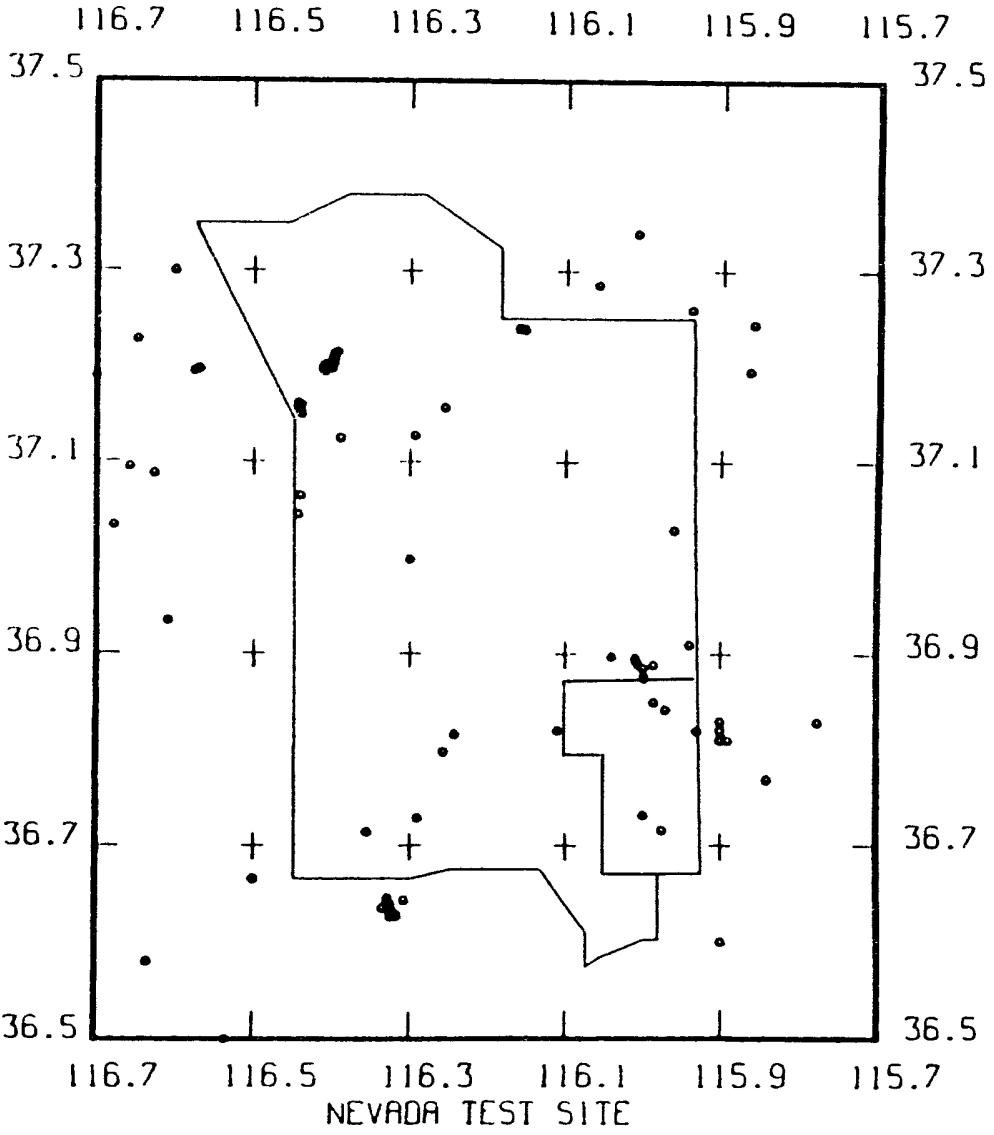

(b)

TRI-6331-88-0

Figure E-4. Seismic Events in the NTS Area with Magnitudes from 2.0 to 3.0, SGBHC Data Base. (a) All Events; (b) Naturally Occurring Events Only (after Vortman, 1991). 

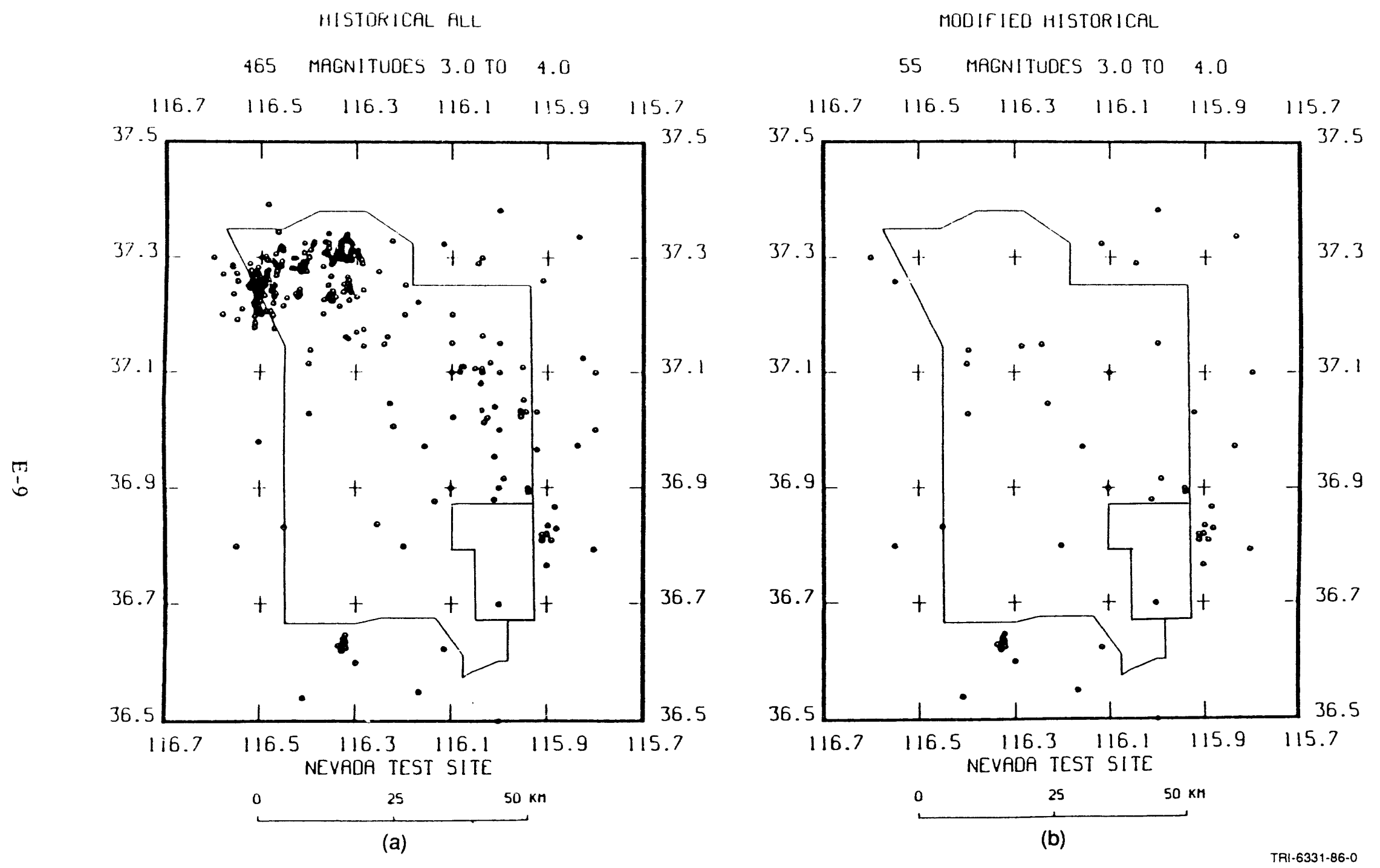

Figure E-5. Seismic Events in the NTS Area with Magnitudes from 3.0 to 4.0, SGBHC Data Base. (a) All Events; (b) Naturally Occurring Events Only (after Vortman, 1991). 


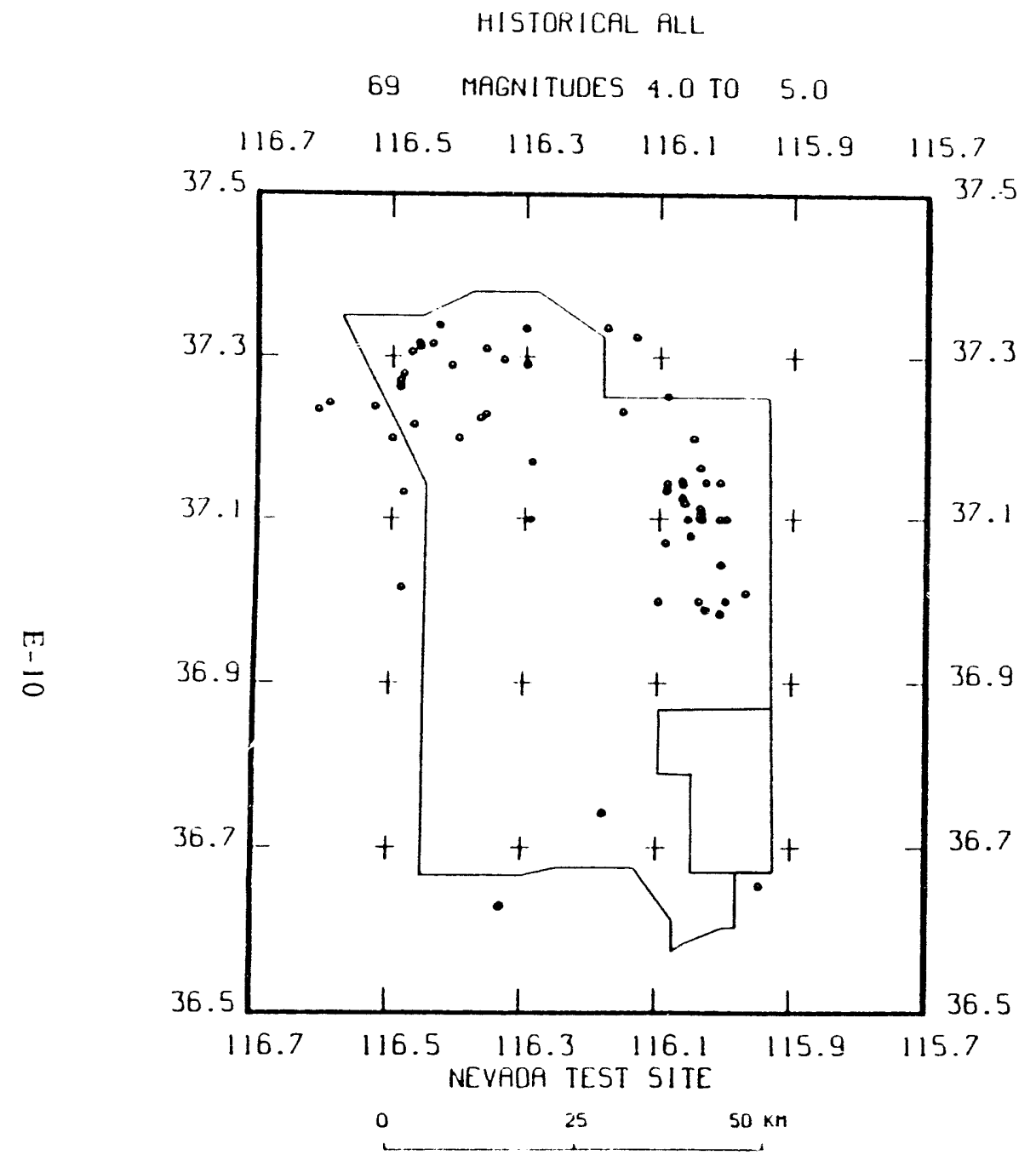

(a)

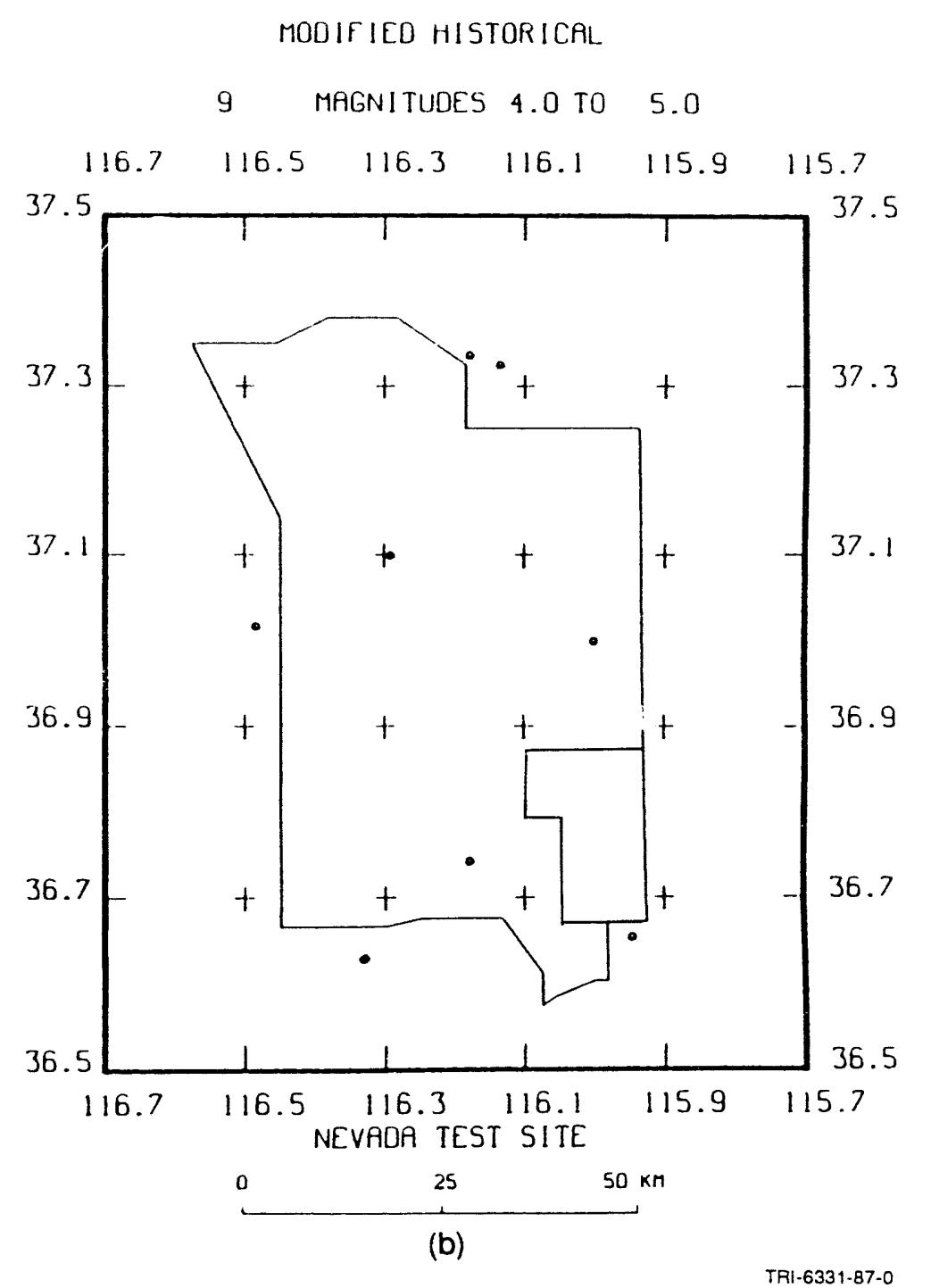

Figure E-6. Seismic Events in the NTS Area with Magnitudes from 4.0 to 5.0, SGBHC Data Base. (a) All Events; (b) Naturally Occurring Events Only (after Vortman, 1991). 

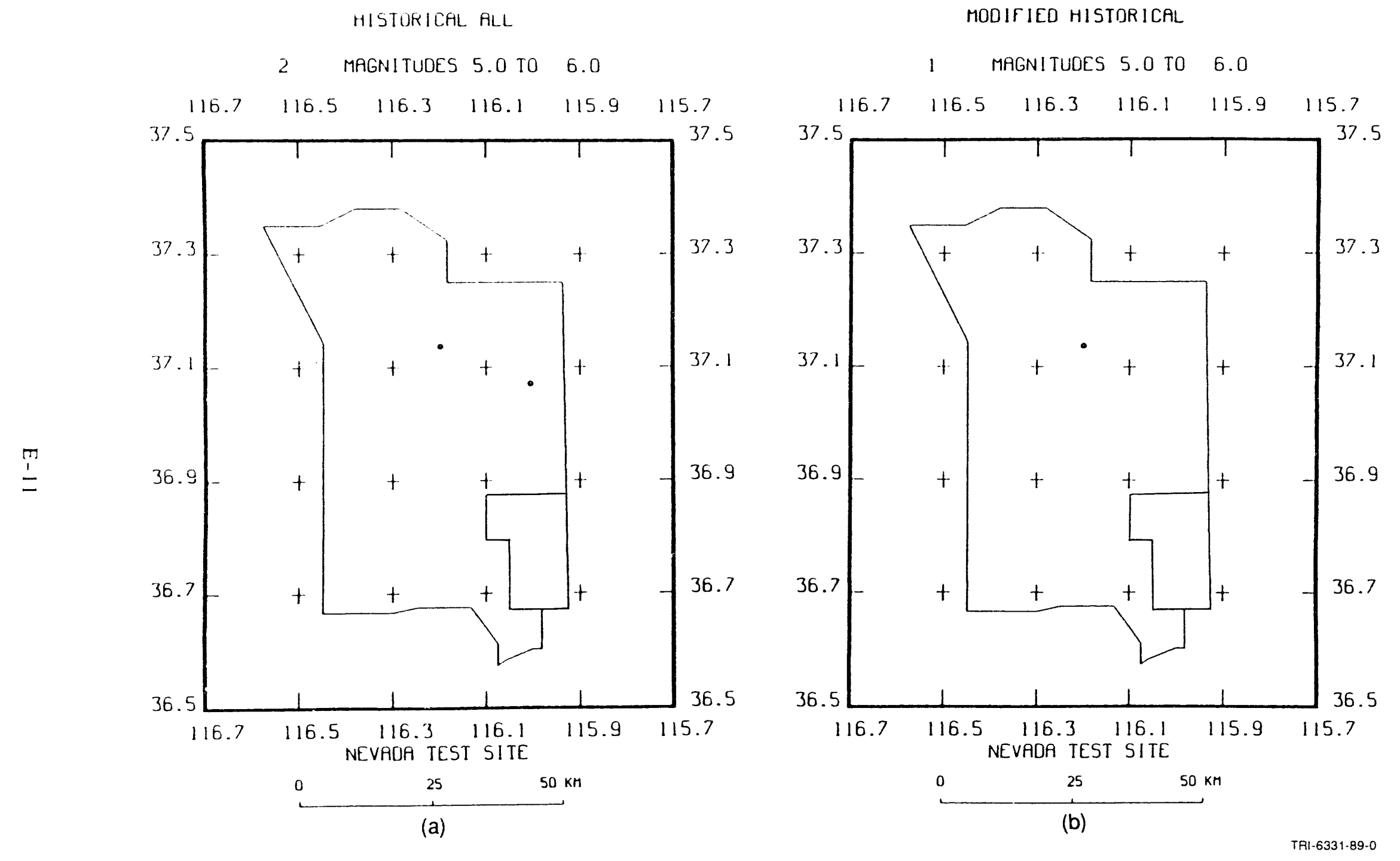

Figure E-7. Seismic Events in the NTS Area with Magnitudes from 5.0 to 6.0, SGBHC Data Base. (a) All Events; (b) Naturally Occurring Events Only (after Vortman, 1991). 


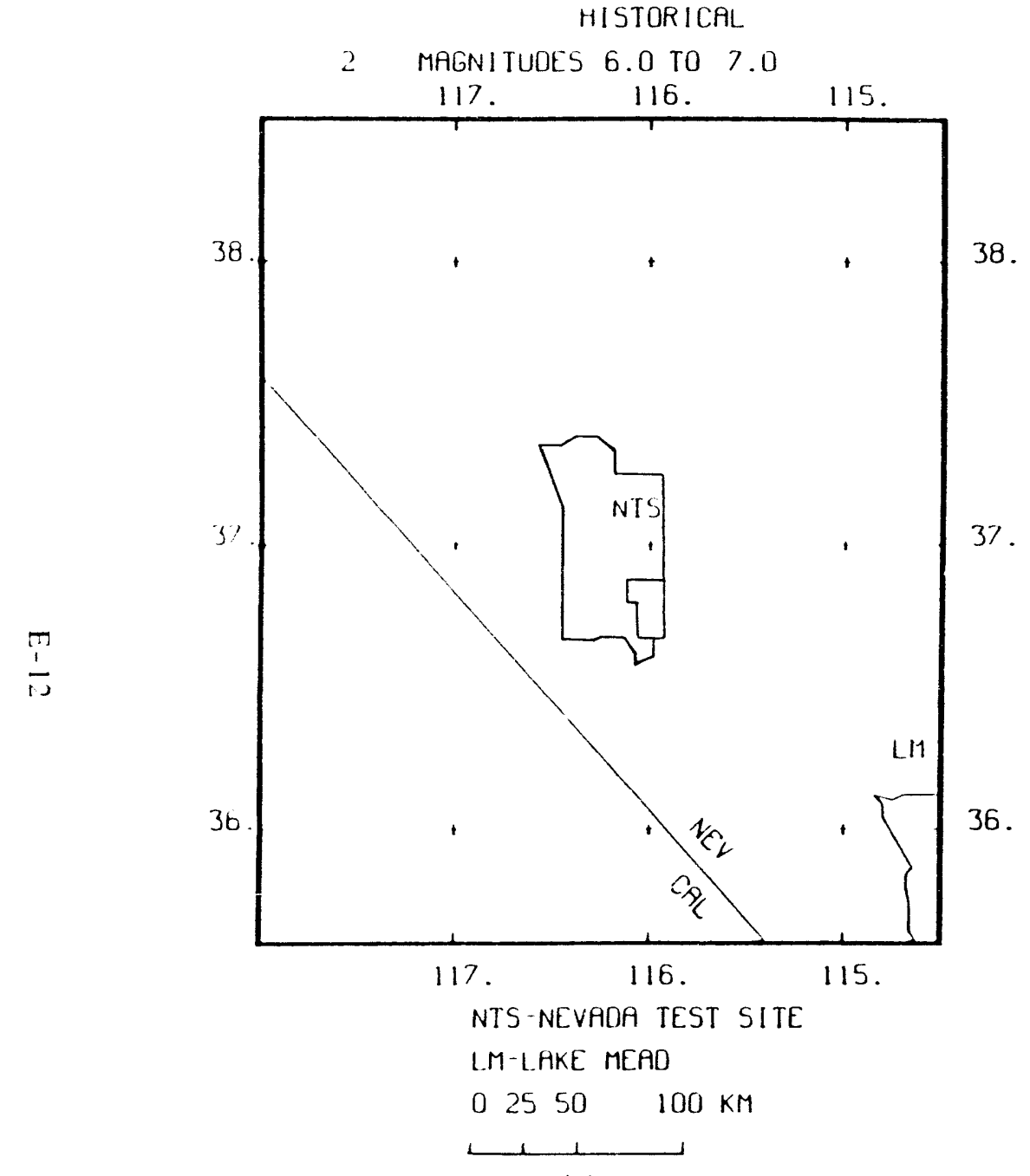

(a)

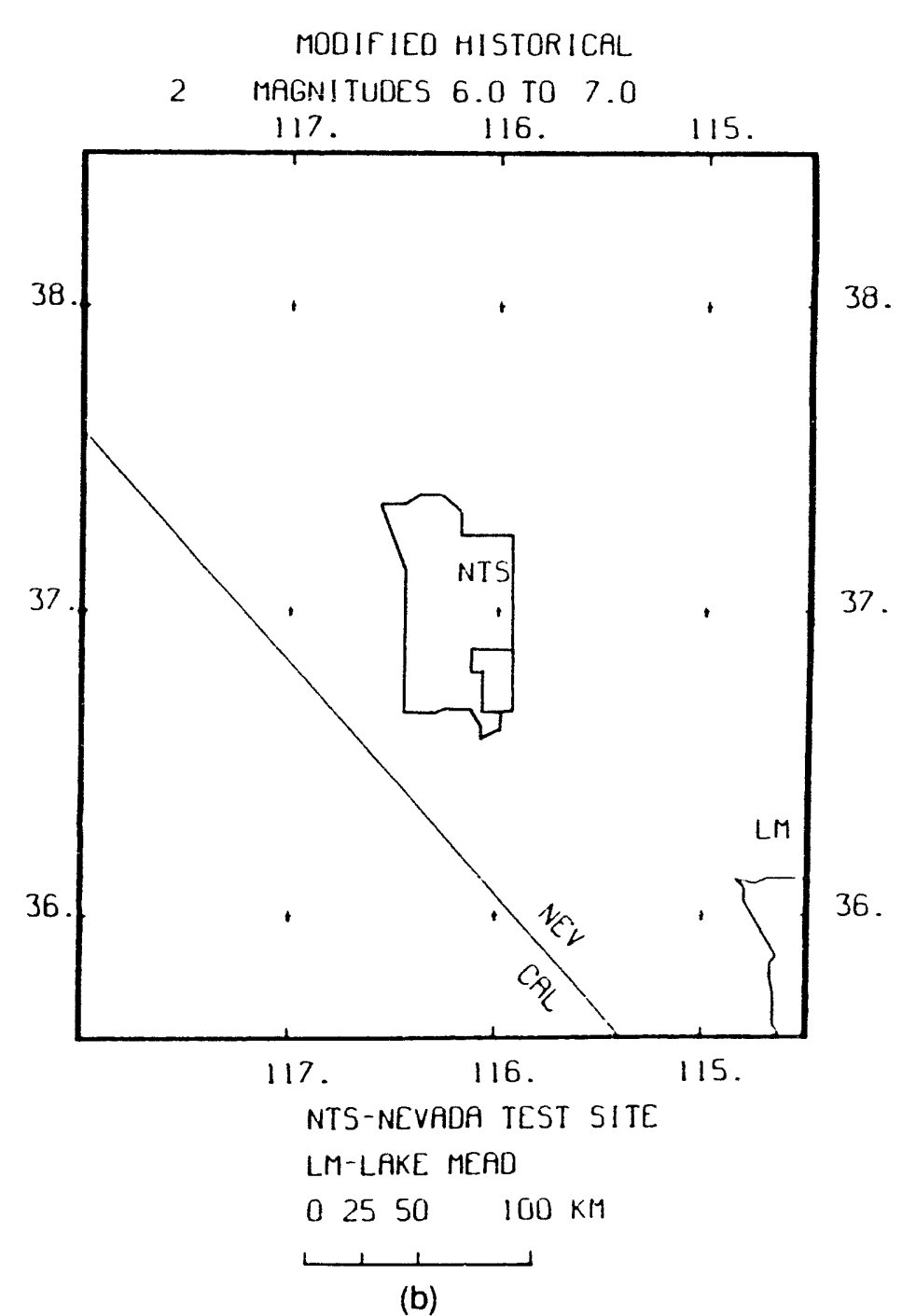

TRI-6331-79-0

Figure 5-8. Seismic Events in the NTS Area with Magnitudes from 6.0 to 7.0, SGBHC Data Base. (a) All Events; (b) Naturally Occurring Events Only (after Vortman, 1991). [no events of these magnitudes recorded] 


\section{REFERENCES}

Nevada Operations Office, 1987. Announced United States Nuclear Tests July 1945 through December 1986, NVO-209 (Rev. 7), U.S. Department of Energy, Las Vegas, NV.

Vortman, L.J., 1991. An Evaluation of the Seismicity of the Nevada Test Site and Vicinity, SAND86-7006, Sandia National Laboratories, Álbuquerque, NM. 
APPENDIX F

PLUTONIC AND VOLCANIC ACTIVITY IN THE NTS REGION

F-1 


\section{APPENDIX F: PLUTONIC AND VOLCANIC ACTIVITY IN THE NTS REGION}

\section{Plutonic Activity}

Most of the intrusive igneous rocks in the NTS region are of Tertiary age and associated with volcanic activity (Figure F-1). Three stocks in the northern portion of the NTS are pre-Tertiary in age and magmatic in origin (Figure F-1). Radiometric age dates for the Climax Stock indicate an age of from 89 to 97 million years old (Maldonado, 1977; Naeser and Maldonado, 1981). The Gold Meadows Stock has been dated at 130 to 140 million years (Gibbons et al., 1963) and 91.8 million years (Marrvin et al., 1970). No age dates are available for the Twin Ridge Stock, although a genetic relationship with the Climax Stock has been suggested by Maldonado (1977).

\section{$\underline{\text { Volcanic Activity }}$}

Two phases of volcanism of Tertiary and post-Tertiary age have occurred in the NTS region. The first phase was silicic volcanism, which generally is accompanied by explosive eruption followed by caldera collapse, and resurgent-dome formation within the collapsed caldera. Extensive faulting and fracturing occur in the vicinity of such an eruptive center. An eruption of this type at or near a disposal system would cause major disruptions of the disposal system either through the direct exhumation of nuclear waste and dispersal in the accessible environment or through disruption of the geologic and hydrologic systems.

In the NTS area, silicic volcanism began approximately 28 million years ago and continued until approximately 6 million years ago (Sinnock, 1982). During this period of time, the maximum duration of quiescence was about 2 million years (Table F-1). The six million years since the last silicic eruption is without precedent over the previous 22 million years during which silicic volcanism occurred in the NTS region. This extended time interval of inactivity in the presence of relatively low geothermal conditions (Muffler, 1979) suggests that the processes that resulted in silicic volcanic activity are not currently active and are not likely to be reinitiated within the 10,000 years of regulatory concern for performance assessments.

The second phase of volcanic activity resulted in basaltic activity, which can be separated into two categories. Older basaltic rocks are associated with the late states of silicic volcanism (Byers et al., 1976; Christiansen et al., 1977). Younger basaltic activity is associated with zones of extensional faulting (Crowe and Carr, 1980). Although the younger type of basaltic volcanism overlaps in time with the late stages of silicic volcanism (Crowe and Carr, 1980); Sinnock, 1982), this type of basaltic volcanism associated with extensional tectonics is the only type of volcanic activity that has occurred in the region within the past 6 million years. The distribution and ages of basaltic rocks in the NTS area are indicated in Figures F-2 and F-3. Although the 
younger basaltic rocks in the region are reported to be 0.3 million years old in Figure F3 (LW-Lathrop Wells; SB-Sleeping Butte), more recent work has indicated the age of recurrent volcanic activity at the Lathrop Wells cone to have started 150,000 years ago with the most recent activity at approximately 20,000 years ago (Crowe et al., 1992; Wells et al., 1990; Perry and Crowe, 1992; Crowe et al., 1988; Valentine et al., 1992).

Local basaltic flows of Tertiary or Quaternary age that may correlate with the basalt at Kiwi Mesa, which is north-northwest of the RWMS and outside the boundaries of Frenchman Flat (Figure F-3), have been reported within the alluvial deposits of the northern part of Frenchman Flat (Carr et al., 1975). The U.S. Geological Survey has recently completed the age dating of basalt samples from boreholes near the GCD facility. Preliminary results indicate ages of 8.6 million years (Rawlinson, 1993), which is Tertiary (see Appendix A). A literature review and field investigations by Raytheon Services Nevada have found no evidence of feeder dikes or lava flows younger than the basalt samples dated by the U.S. Geological Survey (Rawlinson, 1993). 


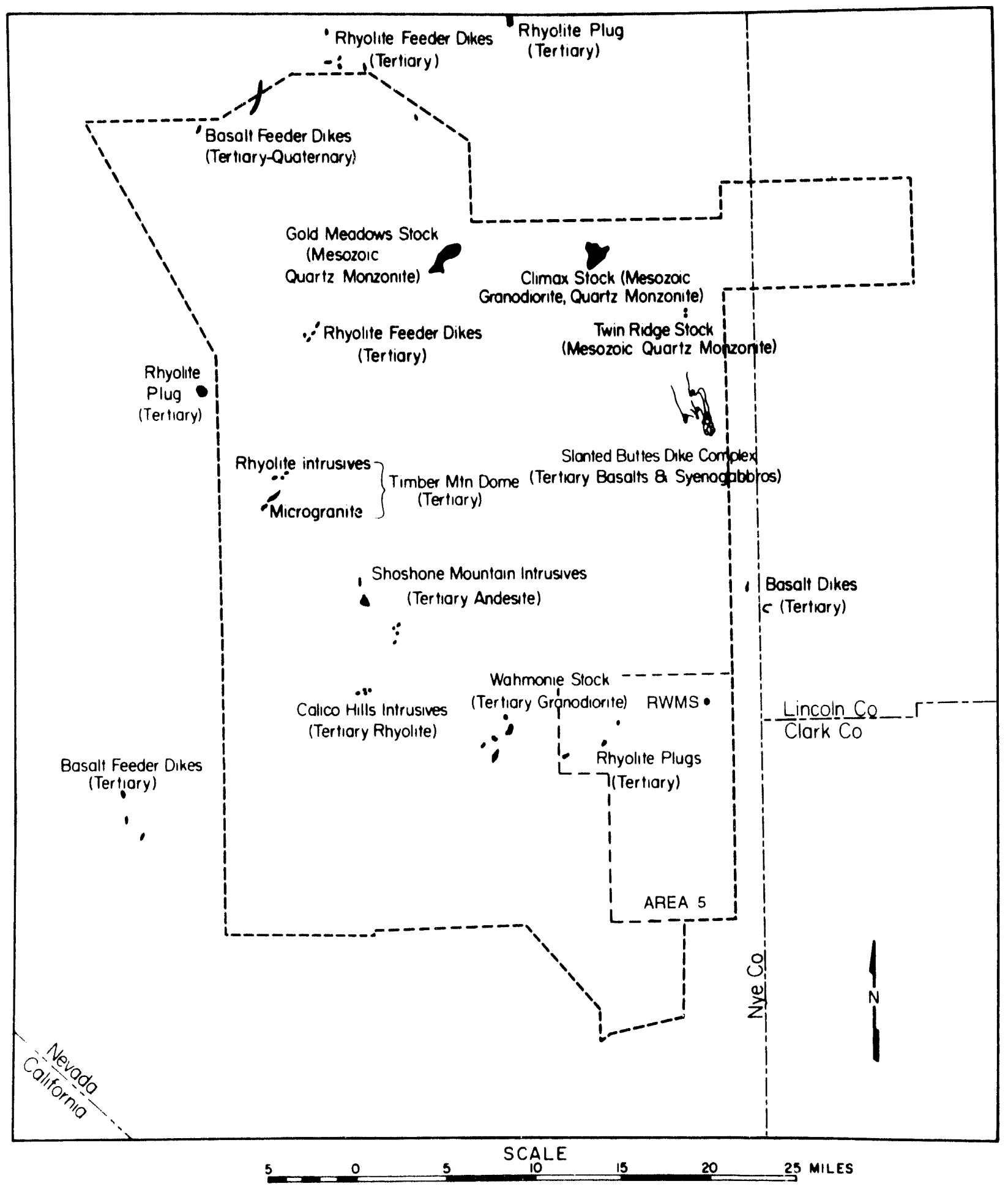

TFI. 6331.82 .0

Figure F-1. Locations of Exposed Intrusive Rocks in the NTS Area (after Sinnock, 1982) 
Table F-1. Volcanic Stratigraphy of the NTS Area (Sinnock, 1982)

\begin{tabular}{|c|c|c|c|c|c|}
\hline EPOCH & $\begin{array}{l}\text { ERUPTIVE } \\
\text { CENTER }\end{array}$ & FORMATION & $\begin{array}{l}\text { MEMBERS OR } \\
\text { RELATED UNITS }\end{array}$ & $\begin{array}{l}\text { RADIOMETRIC } \\
\text { AGE }-10^{6} \text { YRS }\end{array}$ & $\begin{array}{l}\text { ESTIMATED } \\
\text { VOLUME }-\mathrm{MI}^{3}\end{array}$ \\
\hline \multirow{2}{*}{ 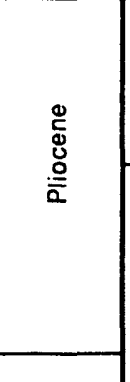 } & $\begin{array}{l}\text { Black Mountain } \\
\text { Caldera }\end{array}$ & Thirsty Canyon Tuff & $\begin{array}{l}\text { Labyrinth Canyon Member } \\
\text { Gold Flat Member } \\
\text { Trail Ridge Member } \\
\text { Spearhead Member } \\
\text { Rocket Wash Member }\end{array}$ & $6 \cdot 8$ & 50 \\
\hline & $\begin{array}{l}\text { Timber Mountain } \\
\text { Caldera }\end{array}$ & Timber Mountain Tuff & $\begin{array}{l}\text { Rhyolites of Shoshone Mountain } \\
\text { Mafic Lavas of Dome Mountain } \\
\text { Rhyolites of Forty Mile Canyon } \\
\text { Tuffs of Crooked Canyon and } \\
\text { Buttonhook Wash } \\
\text { Ammonia Tanks Member } \\
\text { Rainier Mesa Member }\end{array}$ & $9.5-11.5$ & $\begin{array}{l}\text { ? But Small } \\
\text { ? But Small } \\
\text { ? But Small } \\
230 \\
300\end{array}$ \\
\hline \multirow{13}{*}{ 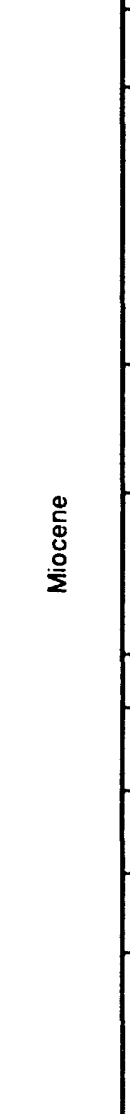 } & $\begin{array}{l}\text { Wahmonie- } \\
\text { Mt. Salyer Area }\end{array}$ & $\begin{array}{l}\text { Wahmonie Formation } \\
\text { Salyer Formation }\end{array}$ & $\begin{array}{l}\text { Multiple Rhyolite, Andesite and } \\
\text { Breccia Flows, and Thin Tulfs }\end{array}$ & $12 \cdot 13$ & $50 ?$ \\
\hline & \multirow[t]{2}{*}{$\begin{array}{l}\text { Claim Canyon } \\
\text { Caldera- } \\
\text { Calico Hills }\end{array}$} & Paintbrush Tuff & $\begin{array}{l}\text { Rhyolite Flows } \\
\text { Tiva Canyon Member } \\
\text { Yucca Mountain Member } \\
\text { Lava Flows } \\
\text { Pah Canyon Member } \\
\text { Topopah Springs Member }\end{array}$ & $12 \cdot 13$ & $\begin{array}{c}? \\
250 \\
4 \\
? \\
5 \\
60\end{array}$ \\
\hline & & Calico Hills Formation & $\begin{array}{l}\text { Rhyolites of Calico Hills } \\
\text { Ashilow and Ashfall Tuffs }\end{array}$ & $13-14$ & $?$ \\
\hline & \multirow{2}{*}{$\begin{array}{l}\text { Silent Canyon } \\
\text { Caldera }\end{array}$} & Stockade Wash Tuff & & $13 \cdot 15$ & $5 \cdot 10$ \\
\hline & & Belted Range Tuff & $\begin{array}{l}\text { Grouse Canyon Member } \\
\text { Tub Springs Member }\end{array}$ & $13 \cdot 15$ & 75 \\
\hline & \multirow{2}{*}{$\begin{array}{l}\text { Crater Flat Area- } \\
\text { Sleeping Butte } \\
\text { Caldera }\end{array}$} & Crater Flat Tulf & $\begin{array}{l}\text { Prow Pass Member } \\
\text { Bullfrog Member } \\
\text { Tram Member }\end{array}$ & $14 \cdot 15$ & 300 \\
\hline & & Red Rock Valley Tuff & & $14-16$ & ? But Small \\
\hline & Mt. Helen & Tolicha Peak Tuff & Multiple Cooling Units & $>14$ & $?$ \\
\hline & $\begin{array}{l}\text { Kane Springs } \\
\text { Wash Caldera }\end{array}$ & Kane Wash Tuff & $\begin{array}{l}\text { Multiple Cooling Units } \\
\text { Lava Flows }\end{array}$ & $14 \cdot 15$ & 200 \\
\hline & $\begin{array}{l}\text { Caclus - Kawich } \\
\text { Ranges }\end{array}$ & Rhyolite lava Flows & $\begin{array}{l}\text { O'Brien's Knob, Cactus Peak } \\
\text { Belted Peak, Ocher Ridge }\end{array}$ & $14 \cdot 15$ & 200 \\
\hline & $\begin{array}{l}\text { Cathedral Ridge } \\
\text { Caldera }\end{array}$ & Fraction Tuff & Multiple Cooling Units & $15 \cdot 18$ & 500 \\
\hline & \multirow{3}{*}{$\begin{array}{l}\text { Mi. Helen, } \\
\text { Cactus - Kawich } \\
\text { Ranges }\end{array}$} & $\begin{array}{l}\text { Flows of Intermediate } \\
\text { Composition }\end{array}$ & Dacites, Andesites, Quartz Latites & $18 \cdot 22$ & $?$ \\
\hline & & $\begin{array}{l}\text { White Blotch Spring } \\
\text { Tuff }\end{array}$ & Multiple Cooling Units & $24 \cdot 25$ & 500 \\
\hline \multirow{2}{*}{$\begin{array}{l}\text { Oli- } \\
\text { gocene }\end{array}$} & & Antelope Valley Tuff & Multiple Cooling Units & $26-27$ & $?$ \\
\hline & Pancake Range & Monotony Tuft & Multiple Cooling Units & $26 \cdot 28$ & 1000 \\
\hline
\end{tabular}




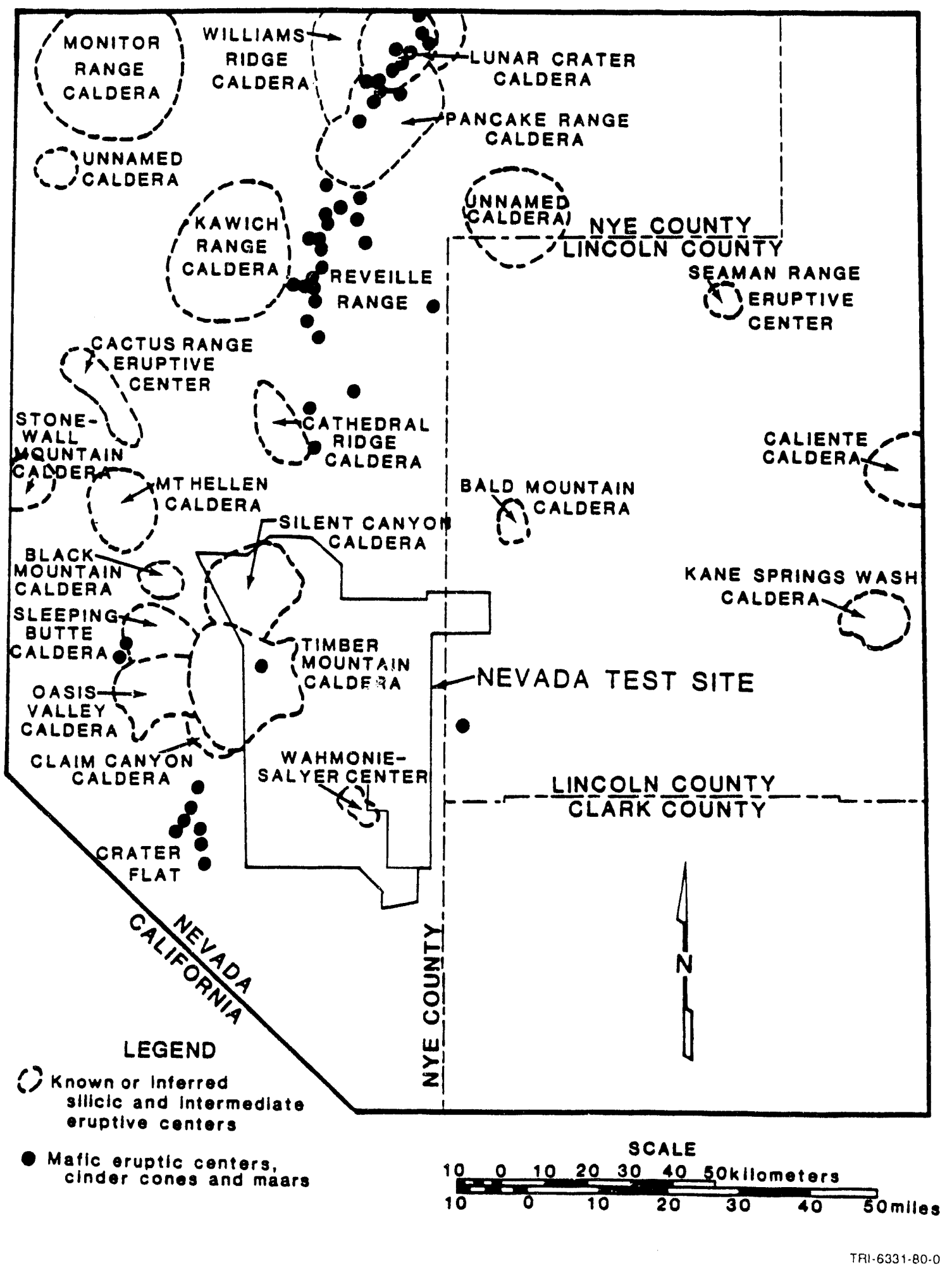

Figure F-2. Eruptive Volcanic Centers in the NTS Region (after Case et al., 1984) 


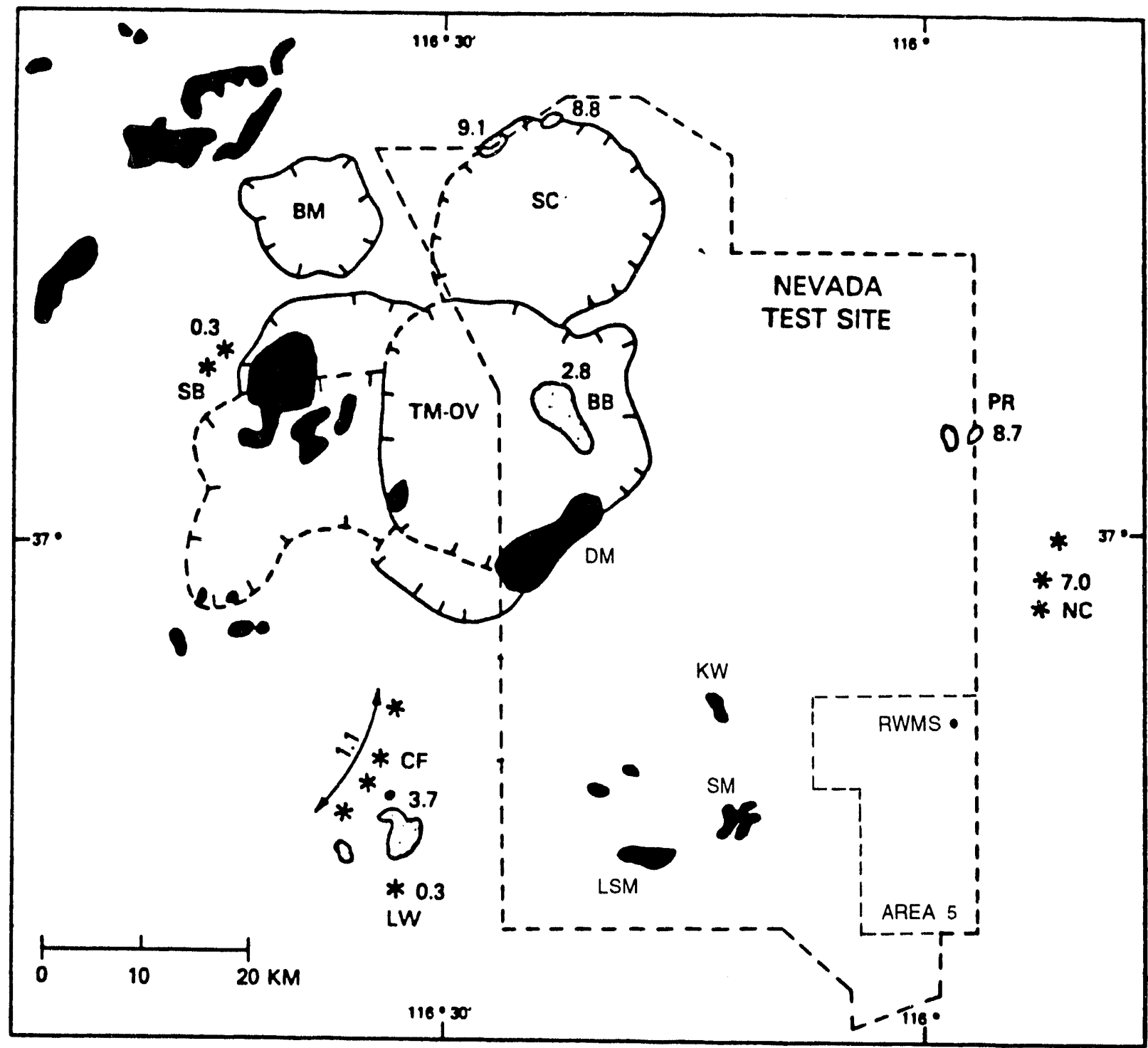

TRI. 6331.81 .0

Hatchured enclosures: centers of silicic volcanic activity. TM-OV: Timber Mountain-Oasis Valley Caldera Complex; SC: Silent Canyon Caldron; BM: Black Mountain Caldera Complex.

Black areas: outcrop areas of silicic-cycle basaltic rocks. DM: Dome Mountain; KW: Kiwi Mesa; LSM: Little Skull Mountain; SM: Skull Mountain.

White areas and star symbols: postsilicic-cycle basalts, including in order of increasing age--LW: Lathrop Wells; SB: basalt of Sleeping Butte; CF: basalt of Crater Flat; BB: basalt of Buckboard Mesa; NC: basalt of Nye Canyon; PR: basalt of Paiute Ridge; SCR: basalt of Silent Canyon ring fracture zone. Numbers are approximate ages of each basalt center in millions of years.

RWMS: approximate location of Radioactive Waste Management Site.

Figure F-3. Distribution of basaltic rocks in the NTS region (after Crowe et al., 1982). 


\section{REFERENCES}

Byers, F.M., Jr., W.J. Carr, P.P. C.kild, W.D. Quinlivan, and K.A. Sargent, 1976. Volcanic Suites and Related Cauldrons of Timber Mountain--Oasis Valley Caldera Cumplex, Southern Nevada, Professional Paper 919, U.S. Geological Survey, Washington, D.C.

Carr, W.J., G.D. Bath, D.L. Healey, and R.M. Hazelwood, 1975. Geology of Northern Frenchman Flat, Nevada Test Site, USGS-474-216, U.S. Geological Survey, Denver, CO.

Case, C., J. Davis, R. French, and S. Raker, 1984. Site Characterization in Connection with the Low Level Defense Waste Management Site in Area 5 of the Nevada Test Site, Nye County, Nevada--Final Report, DOE/NV/10162-13, Desert Research Institute, Reno, NV.

Christiansen, R.L., P.W. Lipman, W.J. Carr, F.M. Byers, Jr., P.P. Orkild, and K.A. Sargent, 1977. "Timber Mountain--Oasis Valley Caldera Complex of Southern Nevada", Bulletin of the Geological Society of America, Vol. 88, no. 7, p. 943-959.

Crowe, B.M., 1990. "Basaltic Volcanic Episodes of the Yucca Mountain Region", in High Level Radioactive Waste Management, Proceedings of the International Topical Meeting, April 8-12, 1990, Las Vegas, NV, American Nuclear Society, Inc., La Grange Park, IL, Vol. 1, p. 65-73.

Crowe, B.M., and W.J. Carr, 1980. Preliminary Assessment of the Risk of Volcanism at a Proposed Nuclear Waste Repository in the Southern Great Basin, Open-File Report 80-357, U.S. Geological Survey, Denver, CO.

Crowe, B., R. Amos, F. Perry, S. Self, and D. Vaniman, 1982. Aspects of Possible Magmatic Disruption of a High-Level Radioactive Waste Repository in Southern Nevada, LA-9326-MS, Los Alamos National Laboratory, Los Alamos, NM.

Crowe, B.M., C. Harrington, L. McFadden, F. Perry, S. Wells, B. Turrin, and D. Champion, 1988. Preliminary Geologic Map of the Lathrop Wells Volcanic Center, LA-UR-88-4155, Los Alamos National Laboratory, Los Alamos, NM.

Crowe, B.M., R. Picard, G. Valentine, and F.V. Perry, 1992. "Recurrence Models of Volcanic Events: Applications to Volcanic Risk Assessment," in High Level Radioactive Waste Management. Proceedings of the Third International Conference, April 12-16, 1992, Las Vegas, NV, American Nuclear Society, Inc., La Grange Park, IL, Vol. 2, p. 2344-2355. 
Gibbons, A.B., E.N. Hinrichs, W.R. Hansen, and R.W. Lemke, 1963. Geology of the Rainier Mesa Quadrangle, Nye County, Nevada, Geologic Quadrangle Map GQ215, U.S. Geological Survey, Washington, D.C.

Maldonado, F., 1977. Summary of the Geology and Physical Properties of the Climax Stock, Nevada Test Site, Open-File Report 77-0356, U.S. Geological Survey, Washington, D.C.

Marvin, R.F., F.M. Byers, Jr., H.H. Mehnert, P.P. Orkild, and T.W. Stern, 1970. "Radiometric Ages and Stratigraphic Sequence of Volcanic and Plutonic Rocks, Southern Nye and Western Lincoln Counties, Nevada," Geological Society of America Bulletin, Vol. 81, no. 9, p. 2657-2676.

Muffler, L.J.P., ed., 1979. Assessment of Geothermal Resources of the United States$\underline{-1978}$, Geological Survey Circular 790, U.S. Geological Survey, Washington, D.C.

Naeser, C.W., and F. Maldonado, 1981. Fission-Track Dating of the Climax and Gold Meadows Stocks, Nye Country, Nevada, Professional Paper 1199-E, U.S. Geological Survey, Washington, D.C, p. 45-47.

Perry, F.V., and B.M. Crowe, 1992. "Geochemical Evidence for Waning Magmatism and Polycyclic Volcanism at Crater Flat, Nevada," in High Level Radioactive Waste Management, Proceedings of the Third International Conference, April 12-16, 1992, Las Vegas, NV, American Nuclear Society, Inc., La Grange Park, IL, Vol. 2, p. 2356-2365.

Rawlinson, S.E., 1993. Transmittal of Comments Regarding Performance Assessment and Geologic Studies at the Area 5 Radioactive Waste Management Site, Letter to P. Davis, Waste Management Systems Department, Sandia National Laboratories, dated August 26, 1993, Raytheon Services Nevada, Las Vegas, NV.

Sinnock, S., 1982. Geology of the Nevada Test Site and Nearby Areas, SAND82-2207, Sandia National Laboratories, Albuquerque, NM.

Valentine, G.A., B.M. Crowe, and F.V. Perry, 1992. "Physical Processes and Effects of Magmatism in the Yucca Mountain Region," in High Level Radioactive Waste Management, Proceedings of the Third International Conference, April 12-16, 1992, Las Vegas, NV, American Nuclear Society, Inc., La Grange Park, IL, Vol. 2 , p. 2014-2024.

Wells, S.G., L.D. McFadden, C.E. Renault, and B.M. Crowe, 1990. "Geomorphic Assessment of Late Quaternary Volcanism in the Yucca Mountain Area, Southern 
Nevada: Implications for the Proposed High-Level Radioactive Waste Repository," Geology, Vol. 18, no. 6, p. 549-553. 


\section{DISTRIBUTION LIST}

Federal Agencies

U.S. Department of Energy

Office of Environmental Restoration and Waste Management

Attn: T.P. Grumbly, EM-1

Forrestal Building

Washington, D.C. 20585-0002

U.S. Department of Energy (3)

Office of Environmental Restoration and Waste Management

Attn: M. Frei, EM-34, Trevion II

Director, Waste Management Projects

Washington, D.C. 20585-0002

U.S. Department of Energy (9)

Office of Environmental Restoration and

Waste Management

Attn: David Huizenga, EM-30

Jill E. Lytle, EM-30

Warren Black, EM-322

Joseph Boda, EM-322

Wayne Nobles, EM-321

Joe Coleman, EM-35

Leanne Smith, EM-60

Jay Rhoderick, EM-351

Tim Harms, EM-351

Washington, D.C. 20585-0002

U.S. Department of Energy (10)

Nevada Field Office

Attn: Doug Duncan

Joe Fiore

Joe Ginanni (5)

Layton O'Neill

Don Vieth

Technical Information Office

2743 S. Highland Drive

Las Vegas, NV 89193-8518

U.S. Department of Energy

WIPP Project Integration Office

Attn: Paul Dickman

Cne Park Square, Suite \#90)3

6501 Americas Parkway NE

Albuquerque, NM 87110

U.S. Department of Energy

WIPP Task Force

Attn: B. Bower

12800 Middlebrook Rd., Suite 400)

Germantown, MD 2() 874
U.S. Department of Energy (5)

Office of Environment, Safety and

Health

Attn: R.P. Berube, EH-20

C. Borgstrum, EH-25

R. Pelletier, EH-231

E. Regnier, EH-232

K. Taimi, EH-232

Washington, D.C. 20585

U.S. Department of Energy

WIPP Project Site Office (Carlsbad)

Attn: G. Krantz

P.O. Box 3090

Carlsbad, NM 88221-3090

U.S. Department of Energy

Office of Geologic Disposal

Yucca Mountain Project Office

Attn: Associate Director, RW-20

P.O. Box 98608

Las Vegas, NV 89193-8608

U.S. Department of Energy (3)

Nevada Operations Office

Attn: J.R. Boland

P.K. Fitzsimmons

D. Livingston

2753 S. Highland Drive

Las Vegas, NV 89183-8518

U.S. Department of Energy

Attn: E. Young

Room E-178

GAO/RCED/GTN

Washington, DC 20545

U.S. Environmental Protection Agency

Attn: Reid Rosnick

Mail Code $5303 \mathrm{~W}$

401 M Street S.W.

Washington, D.C. 20460

U.S. Environmental Protection

Agency (2)

Radiation Protection Programs

Attn: M. Oge

ANR-46()

Washington, D.C. 20460) 
U.S. Environmental Protection Agency (3)

Office of Radiation and Indoor Air

Criteria and Standards Division

Attn: Ray Clark William Gunter, Jr. Lawrence Weinstock

Mail Code 6602J

401 M Street S.W.

Washington, D.C. 20460

U.S. Nuclear Regulatory Commission (4) Advisory Committee on Nuclear Waste

Attn: D. Moeller M.J. Steindler

P.W. Pomeroy

W.J. Hinze

7920 Norfolk Ave.

Bethesda, MD 20814

Defense Nuclear Facilities Safety Board

Attn: D. Winters

625 Indiana Ave. NW

Suite 700

Washington, D.C. 20004

Nuclear Waste Technical Review Board

Attn: Library (2)

1100 Wilson Blvd.

Suite 910

Arlington, VA 22209-2297

Office of Management and Budget

Energy and Science Division

Attn: K. Yuracko

725 17th Street NW

Washington, D.C. 20503

Yucca Mountain Project Office

U.S. Department of Energy

Attn: Jerry M. Boak

P.O. Box 98608

Las Vegas, NV 89193

U.S. Nuclear Regulatory Commission

Division of High-Level Waste

Management

Attn: Margaret Federlina

Mail Stop 4-H-3

Washington, D.C. 20555
U.S. Nuclear Regulatory Commission (2)

Attn: R. Codell N. Eisenberg

Mail Stop 4-H-3

Washington, D.C. 20555

\section{National Laboratories}

Battelle Pacific Northwest Laboratories Attn: P.W. Eslinger

MS K2-32

P.O. Box 999

Richland, WA 99352

Idaho National Engineering

Laboratory (3)

Attn: H. Loo

R. Klinger

Darryl Siemer

Mail Stop 5108

Idaho Falls, ID 83403-4000

Idaho National Engineering Laboratory

EG \& G Idaho, Inc.

Attn: Sven Magnusson

P.O. Box 1625

Idaho Falls, ID 83415

\section{Corporations/Members of the Public}

John F. Ahearne

Executive Director, Sigma Xi

99 Alexander Drive

Research Triangle Park, NC 27709

Center for Nuclear Waste Regulatory

Analysis (CNWRA)

Southwest Research Institute

Attn: B. Sagar

P.O. Drawer 28510

6220) Culebra Road

San Antonio, TX 78284

R.L. Bras Consulting Engineers

Attn: Rafael L. Bras

44 Percy Road

Lexington, MA ()2173

Desert Research Institute - North

Attn: Scott Tyler

P.O. Box 6(220)

Reno, NV 89506 
Desert Research Institute - South

Attn: Jenny Chapman

P.O. Box 19040

Las Vegas, NV 89132-0040

Disposal Safety, Inc.

Attn: B. Ross

1660 L Street NW, Suite 314

Washington, D.C. 20036

EG \& G Idaho (3)

1955 Fremont Street

Attn: C. Atwood

C. Hertzler

T.I. Clements

Idaho Falls, ID 83415

Golder Associates, Inc. (2)

Attn: R. Kossik

I. Miller

4104 148th Avenue NE

Redmond, WA 98052

INTERA, Inc.

Attn: W. Nelson

101 Convention Center Drive

Suite 540

Las Vegas, NV 89109

INTERA/M\&O

Attn: A.E. Van Luik

The Valley Bank Center

101 Convention Center Drive

Las Vegas, NV 89109

Raytheon/Environmental Operations (3)

Attn: Dennis Gustafson

Julie Miller

Stuart Rawlinson

222 S. Rainbow, Suite 115

Las Vegas, NV 89128

Reynolds Electrical and Engineering

Company, Inc. (8)

Attn: Dale Daffern

Bob Dodge

Max Dolenc

Brian Dozier

Dudley Emer

Dale Hammermeister

Tom Lindstrom

Greg Shott

Mail Stop 738

P.O. Box 98521

Las Vegas, NV 89193-8521
Science Applications International

Corporation (SAIC)

Attn: H.R. Pratt

10260 Campus Point Drive

San Diego, CA 92121

Science Applications International

Corporation (SAIC) (2)

Attn: C.G. Pflum

D.C. Royer

101 Convention Center Dr.

Las Vegas, NV 89109

Science Applications International

Corporation (SAIC)

Attn: K. Brinster

2109 Air Park Road SE

Albuquerque, NM 87106

University of Hawaii at Hilo

Division of Business Administration \&

Economics, College of Arts \& Science

Attn: S.C. Hora

Hilo, Hawaii 96720-4091

Westinghouse Hanford Co.

Attn: Don Wood

MS HO-33

P.O. Box 1970

Richland, WA 99352

\section{Foreign Agencies}
ANSTO
Lucas Heights Research Laboratories
Attn: P. Duerden
Private Mail Bág No. 1
Menai, NSW 2234, AUSTRALIA
International Atomic Energy Agency
Division of Nuclear Fuel Cycle and Waste
Management (2)
Attn: Shaheed Hossain
Gordon S. Linsley
Wagramerstrasse 5
P.O. Box 100)
A-1400 Vienna, AUSTRIA
Centre d'Etudes de l'Energie Nucléaire
(CEN/SCK)
Attn: J. Marivoet
Boeretang 2(0)
B-24()0 Mol, BELGIUM 
Commission of the European Communities

Attn: Nicolo Cadelli

200, Rue de la Loi

B-1049 Brussels, BELGIUM

Studiecentrum Voor Kernenergie

Centre D'Energie Nucleaire

Attn: A. Bonne

SCK/CEN

Boeretang 200

B-2400 Mol, BELGIUM

Atomic Energy Control Board (AECB)

Waste Management Division

Attn: P. Conlon

P.O. Box 1046

Ottawa, Ontario KIP 559, CANADA

Atomic Energy of Canada Limited (3)

Whiteshell Research Establishment

Attn: M.E. Stevens

B.W. Goodwin

D. Wushke

Pinawa, Manitoba ROE 1L0, CANADA

Atomic Energy of Canada Limited

Whiteshell Research Establishment

Attn: A.G. Wikjord

Manager, Environmental and Safety

Assessment Branch

Pinawa, Manitoba ROE 1L0, CANADA

Teollisuuden Voima Oy (TVO) (3)

Attn: Timo Äikäs

$$
\text { Jukka-Pekka Salo }
$$

Juhani Vira

Annankatu $42 \mathrm{C}$

SF-00100 Helsinki Suomi

FINLAND

Timo Vieno

Technical Research Centre of Finland

(VTT)

Nuclear Energy Laboratory

P.O. Box 208

SF-02151 Espoo, FINLAND

ANDRA

Attn: D. Alexandre, Deputy Director

31 Rue de la Federation

75015 Paris, FRANCE
ANDRA

Attn: Philippe Raimbault

Route du Panorama Robert Schuman

B.P. No. 38

F-92266 Fontenay-aux-Roses Cedex

FRANCE

Centre D'Etudes Nucleaires

De La Vallee Rhone

CEN/VALRHO

Attn: Claude Sombret

S.D.H.A. B.P. 171

30205 Bagnols-Sur-Ceze, FRANCE

Commissariat á l'Energie Atomique

Attn: M. Dominique Greneche

IPSN/DAS/SASICC/SAED

B.P. No. 6

F-92265 Fontenay-aux-Roses Cedex

FRANCE

Division de la Sécurité et de la Protection de l'Environment (DSPE)

Commissariat á l'Energie Atomique

Agence Nationale pour la Gestion des

Déchets Radioactifs (ANDRA)

Attn: Gérald Ouzounian M. Claude Ringeard

Route du Panorama Robert Schuman

B. P. No. 38

F-92266 Fontenay-aux-Roses Cedex

FRANCE

OECD Nuclear Energy Agency

Division of Radiation Protection and

Waste Management

Attn: Claudio Pescatore

Le Seine-Saint Germain

12 , boulevard des Iles

F-92130 Issy-les-Moulineaux, FRANCE

OECD Nuclear Energy Agency (2)

Attn: Jean-Pierre Olivier

Edward S. Patera

Le Seine-Saint Germain

12 , boulevard des Iles

F-92130 Issy-les-Moulineaux, FRANCE

Federal Office for Radiation Protection (BfS)

Attn: Jürgen Wollrath

P.O. Box 10)149

D-38201 Salzgitter

GERMANY 
Gesellschaft für Reaktorsicherheit (GRS)

MBH

Attn: P. Bogorinski

Schwertnergasse 1

D-5000 Köln 1, GERMANY

GSF - Institut für Tieflagerung (2)

Attn: Peter Hirsekorn R. Storck

Theodor-Heuss-Strabe 4

D-3300 Braunschweig, GERMANY

ISMES S.p.A

Attn: Ferrucio Gera

Via del Crociferi 44

I-00187 Rome, ITALY

Japan Atomic Energy Research Institute Attn: Shingo Tashiro

Tokai-Mura, Ibaraki-Ken

319-11, JAPAN

Power Reactor and Nuclear Fuel

Development Corporation (PNC) (2)

Isolation System Research Program

Radioactive Waste Management Project

Attn: Masaru Ito Hiroyuki Umeki

1-9-13, Akasaka, Minato-ku

Tokyo 107, JAPAN

Netherlands Energy Research Foundation (ECN) (2)

Attn: J. Prij

$$
\text { L.H. Vons }
$$

3 Westerduinweg

PO Box 1

NL-1755 ZG Petten, THE

NETHERLANDS

CIEMAT (2)

Instituto de Tecnología Nuclear

Attn: P. Prado

C. Ruiz

Avenida Complutense, 22

E-28040 Madrid, SPAIN

ENRESA (2)

Attn: Jesus Alonso P. Carboneras Martinez

Calle Emilio Vargas, 7

R-28(043 Madrid, SPAIN
Royal Institute of Technology

Automatic Control

Attn: Björn Cronhjort

S-100 44 Stockholm, SWEDEN

Svensk Kärnbränsleforsorjning $\mathrm{AB}$

Project KBS

Attn: Fred Karlsson

Box 5864

S-102 48 Stockholm, SWEDEN

Swedish Nuclear Fuel and Waste

Management Company (SKB) (3)

Attn: Torsten Eng

Nils A. Kjellbert

Box 5864 Tönis Papp

S-102 48 Stockholm, SWEDEN

Swedish Nuclear Power Inspectorate

Statens Kärnkraftinspektion (SKI)

Attn: Johan Andersson

Box 27106

S-102 52 Stockholm, SWEDEN

Swedish Radiation Protection Institute (SSI) (2)

Attn: Conny Hägg

Box 60204

Mikael Jensen

S-104 01 Stockholm, SWEDEN

HSK-Swiss Nuclear Safety Inspectorate Federal Office of Energy

Attn: J. Vigfusson

CH-5232 Villigen-HSK, SWITZERLAND

Nationale Genossenschaft für die

Lagerung Radioaktiver Abfälle (3)

Attn: C. McCombie

F. Van Dorp

P. Zuidema

Hardstrasse 73

CH-5430 Wettingen, SWITZERLAND

Paul Scherrer Institute

Waste Management Programme (2)

Attn: Richard A. Klos

J. Hadermann

CH-5232 Villigen PSI, SWITZERLAND 
AEA Decommissioning \& Radwaste Harwell Laboratory, B60

Attn: D.E. Billington

Departmental Manager-Assessment Studies

Radwaste Disposal R\&D Division

Didcot Oxfordshire OX11 ORA UNITED KINGDOM

AEA Technology

Decommissioning \& Waste Management

Attn: Andrew J. Baker

424.4 Harwell

Didcot Oxfordshire OX11 ORA

UNITED KINGDOM

Department of the Environment: Her

Majesty's Inspectorate of Pollution

Attn: Brian G.J. Thompson

Room A5.33, Romney House

43 Marsham Street

London SW1P 2PY, UNITED

KINGDOM

Galson Sciences Ltd.

Attn: Daniel A. Galson

35, Market Place

Oakham

Leicestershire LE15 6DT

UNITED KINGDOM

Intera Information Technologies

Attn: N.A. Chapman

Park View House

14B Burton Street

Melton Mowbray

Leicestershire LE13 1AE

UNITED KINGDOM

Intera Information Technologies

Attn: David P. Hodgkinson

45 Station Road, Chiltern House

Henley-on-Thames

Oxfordshire RG9 1AT

UNITED KINGDOM

UK Nirex Ltd

Attn: Alan J. Hooper

Curie Avenue

Harwell, Didcot

Oxfordshire, OX11 ORH

UNITED KINGDOM

\begin{tabular}{|c|c|c|}
\hline \multicolumn{3}{|r|}{ Internal } \\
\hline 1351 & 3020 & N. E. Olague \\
\hline 0750 & 6118 & H. W. Stockman \\
\hline 1337 & 6300 & D. Ellis \\
\hline 1335 & 6301 & F. Bingham \\
\hline 1335 & 6302 & L. Shephard \\
\hline 1335 & 6303 & W. D. Weart \\
\hline 1335 & 6305 & S. A. Goldstein \\
\hline 1341 & 6306 & A. L. Stevens \\
\hline 1326 & 6312 & H. Dockery \\
\hline 1326 & 6313 & L. S. Costin \\
\hline 1335 & 6319 & D. Brosseau \\
\hline 1345 & 6331 & GCD Records Center (S33) \\
\hline 1345 & 6331 & T. Baer \\
\hline 1345 & 6331 & S. H. Conrad \\
\hline 1345 & 6331 & P. A. Davis \\
\hline 1345 & 6331 & L. Dubes \\
\hline 1345 & 6331 & F. Duran \\
\hline 1345 & 6331 & J. Emery \\
\hline 1345 & 6331 & T. Feeney \\
\hline 1345 & 6331 & B. Fogleman \\
\hline 1345 & 6331 & D. P. Gallegos (20) \\
\hline 1345 & 6331 & R. V. Guzowski (10) \\
\hline 1345 & 6331 & S. Heger \\
\hline 1345 & 6331 & E. Kalinina \\
\hline 1345 & 6331 & M. W. Kozak \\
\hline 1345 & 6331 & G. C. Newman \\
\hline 1345 & 6331 & L. L. Price \\
\hline 1345 & 6331 & J. Reitzel \\
\hline 1345 & 6331 & L. Snyder \\
\hline 1345 & 6331 & W. Strong \\
\hline 1345 & 6331 & C. D. Updegraff \\
\hline 1345 & 6331 & B. Vocke \\
\hline 1345 & 6331 & E. K. Webb \\
\hline 1328 & 6342 & D. R. Anderson \\
\hline 1328 & 6342 & M. Marietta \\
\hline 1328 & 6342 & P. Swift \\
\hline 1330 & 6352 & Nuclear Waste \\
\hline & & Management Library \\
\hline 0727 & 6622 & M. S. Y. Chu \\
\hline 0727 & 6622 & J. T. McCord \\
\hline 0718 & 6641 & T. Wheeler \\
\hline 1339 & 6903 & G. W. Barr \\
\hline 0743 & 6907 & C. P. Harlan \\
\hline 0743 & 6907 & M. Harrington \\
\hline 0899 & 7141 & Technical Library (5) \\
\hline 0899 & 7141 & S. A. Landenberger (5) \\
\hline $061 s$ & 7151 & G. C. Claycomb (3) \\
\hline 0615 & 7151 & Technical Publications \\
\hline 134 & 7581 & W. B. Cox \\
\hline $134^{7}$ & 7585 & K. C. Gaither \\
\hline 111 & $7613-2$ & $\begin{array}{l}\text { Document Processing for } \\
\text { DOE/OSTI (10) }\end{array}$ \\
\hline 0918 & $8523-2$ & Central Technical Files \\
\hline
\end{tabular}



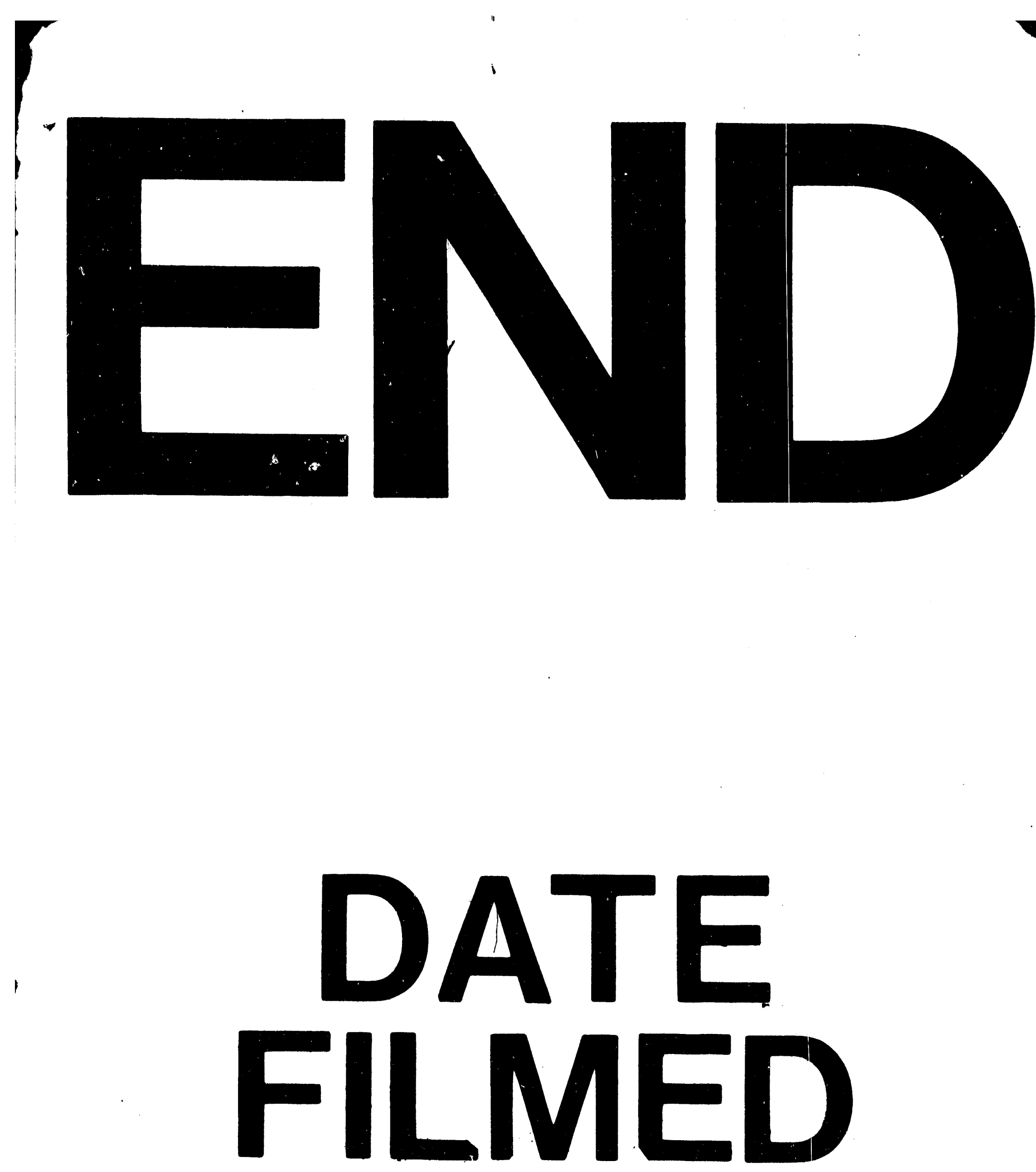

I

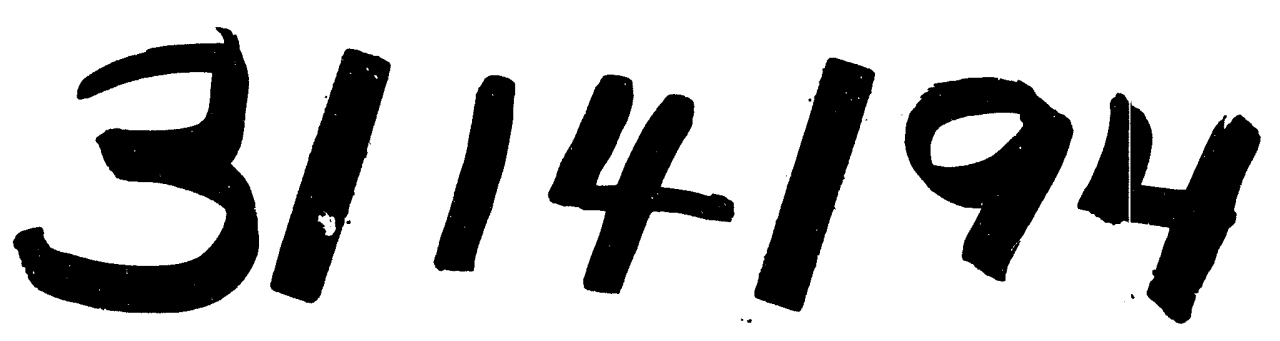



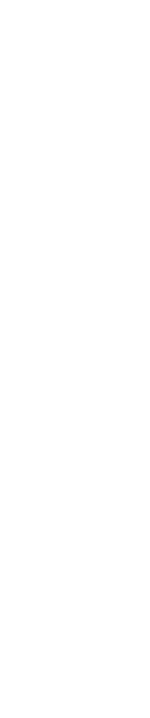

\section{.}
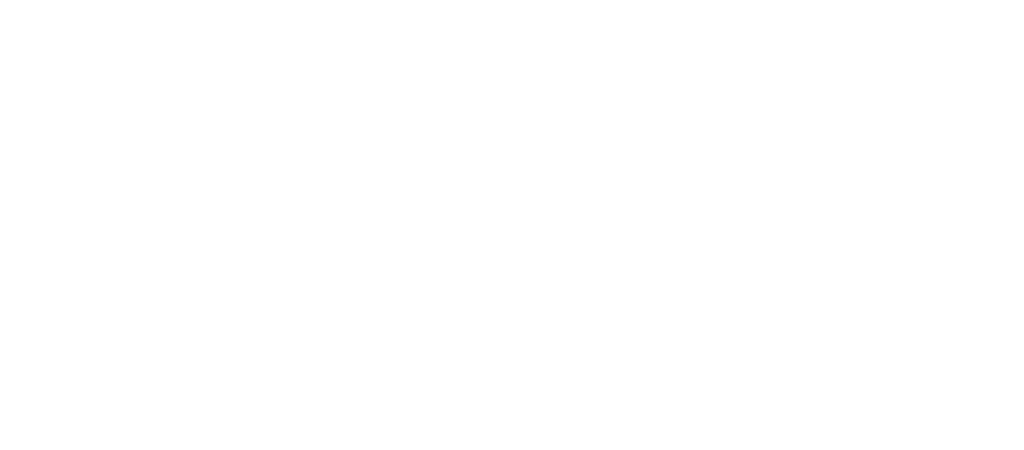